\title{
Multiple Proton-Coupled Electron Transfers at a Tricopper Cluster: Modeling the Reductive Regeneration Process in Multicopper Oxidases
}

\author{
Weiyao Zhang, Curtis E. Moore, Shiyu Zhang* \\ Department of Chemistry and Biochemistry, The Ohio State University, 100 West 18th \\ Avenue, Columbus, Ohio 43210, United States of America \\ *Correspondence to: zhang.8941@osu.edu
}




\section{Contents}

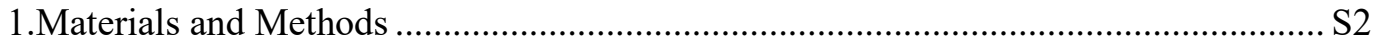

Synthesis and characterization of $\left[\mathbf{T R E N}_{4} \mathrm{Cu}^{\mathrm{II}} \mathrm{Cu}^{\mathrm{II}} \mathrm{Cu}^{\mathrm{II}}\left(\mu_{3}-\mathrm{O}\right) \mathrm{H}\right]\left(\mathrm{PF}_{6}\right)_{5} \ldots \ldots \ldots \ldots \ldots \ldots . . . . . . . . . . . . . . . . . .52$

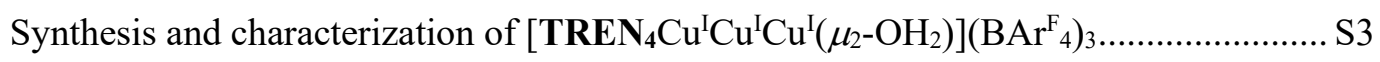

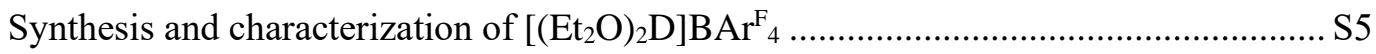

2. UV-Vis Spectroscopy and Kinetic Simulation Details ............................................... 7

Kinetic study of the reaction between $\mathrm{Cu}^{\mathrm{I}} \mathrm{Cu}^{\mathrm{I}} \mathrm{Cu}^{\mathrm{I}}\left(\mu_{3}-\mathrm{OH}\right) \mathbf{L}$ and $\left[\left(\mathrm{Et}_{2} \mathrm{O}\right)_{2} \mathrm{H}\right] \mathrm{BAr}{ }_{4}{ }_{4} \ldots \ldots \ldots . . . \mathrm{S} 7$

Kinetic study of the reaction between $\mathrm{Cu}^{\mathrm{II}} \mathrm{Cu}^{\mathrm{II}} \mathrm{Cu}^{\mathrm{II}}\left(\mu_{3}-\mathrm{O}\right) \mathbf{L H}$ and cobaltocene ............ S11

Kinetic study of the reaction of $\mathrm{Cu}^{\mathrm{II}} \mathrm{Cu}^{\mathrm{I}} \mathrm{Cu}^{\mathrm{I}}\left(\mu_{3}-\mathrm{OH}\right) \mathbf{L},\left[\left(\mathrm{Et}_{2} \mathrm{O}\right)_{2} \mathrm{H}\right] \mathrm{BAr}{ }_{4}$, and $\mathrm{Fc}^{*} \ldots . . . . \mathrm{S} 15$

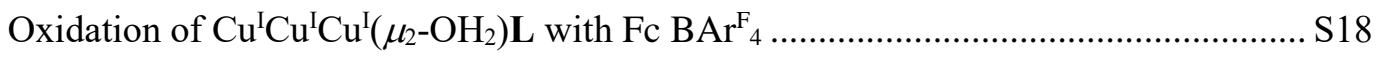

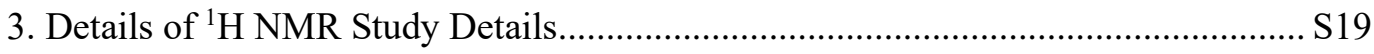

${ }^{1} \mathrm{H} N M R$ study of the reaction of $\mathrm{Cu}^{\mathrm{II}} \mathrm{Cu}^{\mathrm{I}} \mathrm{Cu}^{\mathrm{I}}\left(\mu_{3}-\mathrm{OH}\right) \mathbf{L},\left[\left(\mathrm{Et}_{2} \mathrm{O}\right)_{2} \mathrm{H}\right] \mathrm{BAr}{ }_{4}^{\mathrm{F}}$, and $\mathrm{Fc}^{*}$...... S19

${ }^{1} \mathrm{H} N M R$ study of the reaction of $\mathrm{Cu}^{\mathrm{II}} \mathrm{Cu}^{\mathrm{I}} \mathrm{Cu}^{\mathrm{I}}\left(\mu_{3}-\mathrm{OH}\right) \mathbf{L}$ and $\left[\left(\mathrm{Et}_{2} \mathrm{O}\right)_{2} \mathrm{H}\right] \mathrm{B} \mathrm{Ar}^{\mathrm{F}}{ }_{4} \quad \ldots \ldots \ldots . . . . . \mathrm{S} 20$

${ }^{1} \mathrm{H} N M R$ study of the reaction of $\mathrm{Cu}^{\mathrm{I}} \mathrm{Cu}^{\mathrm{I}} \mathrm{Cu}^{\mathrm{I}}\left(\mu_{3}-\mathrm{OH}\right) \mathbf{L}$ and $\left[\left(\mathrm{Et}_{2} \mathrm{O}\right)_{2} \mathrm{H}\right] \mathrm{BAr}^{\mathrm{F}}{ }_{4} \quad \ldots \ldots \ldots \ldots . . . . . \mathrm{S} 21$

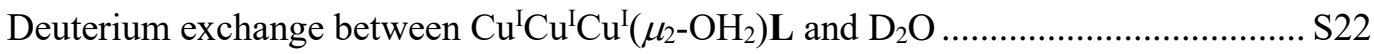

${ }^{1} \mathrm{H}$ NMR study of the reaction of $\mathrm{Cu}^{\mathrm{I}} \mathrm{Cu}^{\mathrm{I}} \mathrm{Cu}^{\mathrm{I}}\left(\mu_{3}-\mathrm{OH}\right) \mathbf{L}$ and $\left[\left(\mathrm{Et}_{2} \mathrm{O}\right)_{2} \mathrm{D}\right] \mathrm{B} \mathrm{Ar}_{4}^{\mathrm{F}}{ }_{4} \ldots \ldots \ldots . . . . \mathrm{S} 22$

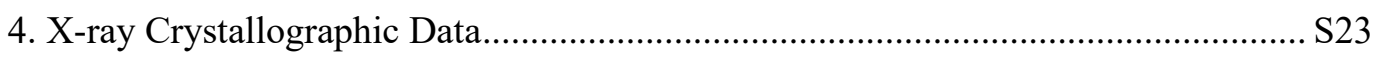

5. UV-vis Spectro-electrochemistry Studies Details.................................................. S26

Reduction of $\mathrm{Cu}^{\mathrm{II}} \mathrm{Cu}^{\mathrm{I}} \mathrm{Cu}^{\mathrm{I}}\left(\mu_{3}-\mathrm{OH}\right) \mathbf{L}$ and $\left[\left(\mathrm{Et}_{2} \mathrm{O}\right)_{2} \mathrm{H}\right] \mathrm{BAr}_{4}{ }_{4}$ mixture by electrolysis $\quad . . . . . \mathrm{S} 26$

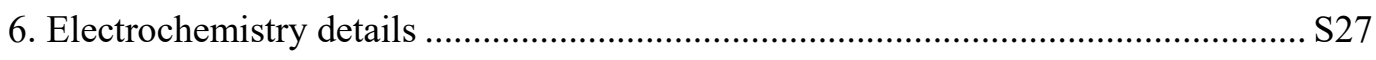

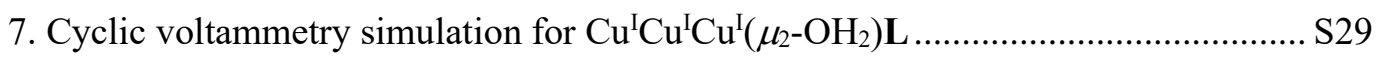

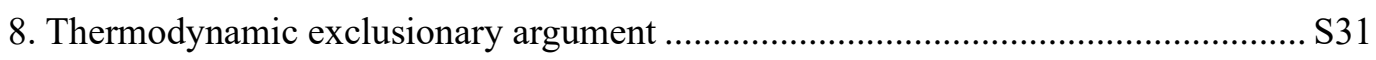

9. Estimation of ET rate between $\mathrm{Cu}^{\mathrm{II}} \mathrm{Cu}^{\mathrm{II}} \mathrm{Cu}^{\mathrm{I}}\left(\mu_{3}-\mathrm{OH}\right) \mathbf{L}$ and $\mathrm{Cu}^{\mathrm{II}} \mathrm{Cu}^{\mathrm{II}} \mathrm{Cu}^{\mathrm{I}}\left(\mu_{3}-\mathrm{O}\right) \mathbf{L H}$..... S32

Estimation of the electron self-exchange rate constants of $\mathrm{Cu}^{\mathrm{II}} \mathrm{Cu}^{\mathrm{II}} \mathrm{Cu}^{\mathrm{I}}\left(\mu_{3}-\mathrm{O}\right) \mathbf{L} \mathbf{H} \quad \ldots . . . \mathrm{S} 32$

Calculation of ET rate between $\mathrm{Cu}^{\mathrm{II}} \mathrm{Cu}^{\mathrm{II}} \mathrm{Cu}^{\mathrm{I}}\left(\mu_{3}-\mathrm{OH}\right) \mathbf{L}$ and $\mathrm{Cu}^{\mathrm{II}} \mathrm{Cu}^{\mathrm{II}} \mathrm{Cu}^{\mathrm{I}}\left(\mu_{3}-\mathrm{O}\right) \mathbf{L H} \quad . . . . . \mathrm{S} 33$

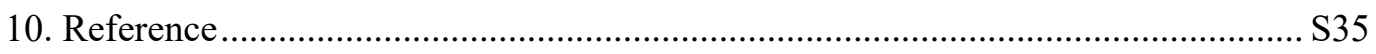




\section{Materials and Methods}

General: All reactions were carried out under a nitrogen atmosphere in an MBraun glovebox or using Schlenk techniques.

Instrumentation: Nuclear magnetic resonance (NMR) spectra were recorded on AVIII 600 $\mathrm{MHz}\left({ }^{1} \mathrm{H}: 600 \mathrm{MHz}\right)$ at ambient temperature if it is not specified. Chemical shift values for protons were referenced to the residual proton resonance of tetrahydrofuran- $d_{8}$ (THF- $d_{8}, \delta: 1.72$ ppm and $3.58 \mathrm{ppm})$. X-ray crystallographic analyses were performed under a cold nitrogen stream (Oxford Cryosystems Cryostream) at $100 \mathrm{~K}\left(\mathrm{Cu}^{\mathrm{II}} \mathrm{Cu}^{\mathrm{II}} \mathrm{Cu}^{\mathrm{II}}\left(\mu_{3}-\mathrm{O}\right) \mathbf{L H}\right.$ and $\mathrm{Cu}^{\mathrm{I}} \mathrm{Cu}^{\mathrm{I}} \mathrm{Cu}^{\mathrm{I}}\left(\mu_{2}-\right.$ $\left.\left.\mathrm{OH}_{2}\right) \mathbf{L}\right)$ on a Bruker D8 Venture instrument with Mo Ka radiation source $(\lambda=0.7107 \AA)$ and a Photon II detector. Elemental analyses were performed by Midwest Micro Lab (Indianapolis, IN, http://midwestlab.com/). ESI mass spectra were recorded on a Bruker MicrOTOF. Solidstate IR was recorded on a Bruker Alpha II FTIR spectrometer. Cyclic voltammogram was performed using Bio-Logic SAS SP-50 with a glassy carbon working electrode, a platinum wire counter electrode and a $\mathrm{Ag} / \mathrm{AgNO}_{3}(0.01 \mathrm{M})$ reference electrode. UV-vis spectra were collected on an Agilent Cary 60 spectrophotometer outfitted with a Unisoku Unispeks cryostat $\left(-100^{\circ} \mathrm{C}\right.$ to $\left.+100{ }^{\circ} \mathrm{C}\right)$.

Materials: Anhydrous acetone was purchased from Acros and was used as received. Dichloromethane, acetonitrile, diethyl ether, and tetrahydrofuran were dried and degassed under nitrogen using a Pure Process Technologies (PPT, Nashua, NH) solvent purification system, and stored over $4 \AA$ molecular sieves. Tetrahydrofuran- $d_{8}$ (Cambridge Isotope Laboratories, Inc.) was deoxygenated by three freeze-pump-thaw cycles and dried over $4 \AA$ molecular sieves prior to use. Cobaltocene (Strem), decamethylferrocene (Sigma-Aldrich), tetra-n-butylammonium tetrafluoroborate (Sigma-Aldrich), tetra- $n$-butylammonium hexafluorophosphate (electrochemical grade, Sigma-Aldrich), hydrogen chloride solution (2 M in diethyl ether, Sigma-Aldrich), and deuterium chloride solution (1 M in diethyl ether, SigmaAldrich) were purchased and used without further purification. Brookhart's acid $\left(\left[\left(\mathrm{Et}_{2} \mathrm{O}\right)_{2} \mathrm{H}\right] \mathrm{BAr}^{\mathrm{F}}{ }_{4}\right),{ }^{1} \quad$ ferrocenium $\quad$ tetrakis[(3,5-trifluoromethyl)phenyl $]$ borate, ${ }^{2} \quad$ tris $(4-$ bromophenyl)ammoniumyl hexafluorophosphate (magic blue), ${ }^{3}$ $\left[\right.$ TREN $\left._{4} \mathrm{Cu}^{\mathrm{II}} \mathrm{Cu}^{\mathrm{I}} \mathrm{Cu}^{\mathrm{I}} \mathrm{OH}\right]\left(\mathrm{PF}_{6}\right)_{3},{ }^{4} \quad\left[\mathrm{TREN}_{4} \mathrm{Cu}^{\mathrm{II}} \mathrm{Cu}^{\mathrm{I}} \mathrm{Cu}^{\mathrm{I} O H}\right]\left(\mathrm{BAr}^{\mathrm{F}}{ }_{4}\right)_{3},{ }^{4}$ and $\left[\right.$ TREN $\left._{4} \mathrm{Cu}^{\mathrm{I}} \mathrm{Cu}^{\mathrm{I}} \mathrm{Cu}^{\mathrm{I}} \mathrm{OH}\right]\left(\mathrm{BAr}_{4}^{\mathrm{F}}\right)_{2}{ }^{4}$ were prepared by published methods.

\section{Synthesis and characterization of $\left[\operatorname{TREN}_{4} \mathrm{Cu}^{\mathrm{II}} \mathrm{Cu}^{\mathrm{II}} \mathrm{Cu}^{\mathrm{II}}\left(\mu_{3}-\mathrm{O}\right) \mathrm{H}\right]\left(\mathrm{PF}_{6}\right)_{5}\left(\mathrm{Cu}^{\mathrm{II}} \mathrm{Cu}^{\mathrm{II}} \mathrm{Cu}^{\mathrm{II}}\left(\mu_{3}-\right.\right.$ O)LH)}

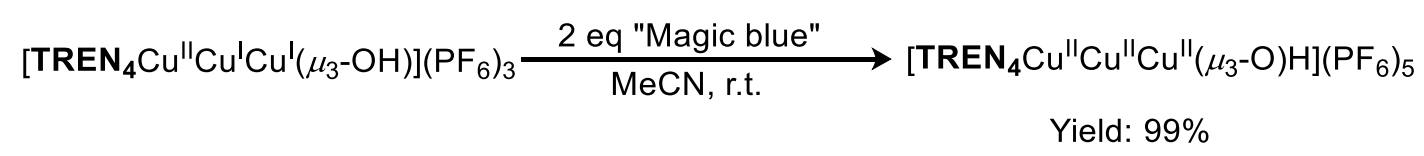

To a MeCN solution ( $3 \mathrm{~mL}$ ) of [ $\left.\mathbf{T R E N}_{4} \mathrm{Cu}^{\mathrm{II}} \mathrm{Cu}^{\mathrm{I}} \mathrm{Cu}^{\mathrm{I}} \mathrm{OH}\right]\left(\mathrm{PF}_{6}\right)_{3}(40 \mathrm{mg}, 0.0292 \mathrm{mmol})$, a MeCN solution ( $2 \mathrm{~mL}$ ) of tris(4-bromophenyl)ammoniumyl hexafluorophosphate (Magic blue) was added dropwise with stirring at room temperature. The mixture was allowed to stir for $5 \mathrm{~min}$. 
All volatiles were removed under vacuum. The obtained earth yellow solid was then washed with DCM $(3 \mathrm{~mL})$. The solid was redissolved in MeCN $(1 \mathrm{~mL})$, followed by the addition of DCM (9 mL). After filtration, the solid was collected and dried under vacuum (48.0 mg, 99\%). In order to obtain single crystals for X-ray diffraction analysis, a counter anion exchange was performed. To an acetone solution $(1.5 \mathrm{~mL})$ of $\mathrm{TBABF}_{4}(11.9 \mathrm{mg}, 0.0361 \mathrm{mmol})$, an acetone solution $(1.5 \mathrm{~mL})$ of the $\left[\mathbf{T R E N}_{4} \mathrm{Cu}^{\mathrm{II}} \mathrm{Cu}^{\mathrm{II}} \mathrm{Cu}^{\mathrm{II}}\left(\mu_{3}-\mathrm{O}\right) \mathrm{H}\right]\left(\mathrm{PF}_{6}\right)_{5}(10 \mathrm{mg}, 0.00602 \mathrm{mmol})$ was added dropwise with stirring at room temperature. A yellow precipitate formed immediately. The suspension was passed through a pipette filter filled with Celite. MeCN (ca. $2 \mathrm{~mL}$ ) was used to extract the yellow precipitate collected on the Celite during the filtration. The $\mathrm{MeCN}$ solvent was evaporated under vacuum to give a yellow solid, which was then redissolved in acetone (2 $\mathrm{mL}$ ) and filtered. Diethyl ether was allowed to slowly diffuse to the filtrate at $-30{ }^{\circ} \mathrm{C}$ for two days to afford yellow crystals suitable for single-crystal X-ray diffraction. In the infrared spectrum (ATR), no signal was observed for $\mathrm{X}-\mathrm{H}(\mathrm{X}=\mathrm{N}, \mathrm{O})$ stretches (Figure 3C in manuscript); UV-Vis spectrum (acetone, Figure S1A), $\lambda_{\max }=690 \mathrm{~nm}\left(1100 \mathrm{M}^{-1} \mathrm{~cm}^{-1}\right)$; ESI-MS spectrum (Figure $\mathrm{S} 1 \mathrm{~B}),\left[\mathbf{T R E N}_{4} \mathrm{Cu}^{\mathrm{II}} \mathrm{Cu}^{\mathrm{II}} \mathrm{Cu}^{\mathrm{II}}\left(\mu_{3}-\mathrm{O}\right) \mathrm{H}\left(\mathrm{PF}_{6}\right)_{3}\right]^{2+}\left(\mathrm{C}_{36} \mathrm{H}_{73} \mathrm{Cu}_{3} \mathrm{~F}_{18} \mathrm{~N}_{16} \mathrm{OP}_{3}{ }^{2+}\right) \mathrm{M} / \mathrm{z}=$ 685.6. Elemental analysis, Calcd for $\left[\mathbf{T R E N}_{4} \mathrm{Cu}^{\mathrm{II}} \mathrm{Cu}^{\mathrm{II}} \mathrm{Cu}^{\mathrm{II}}\left(\mu_{3}-\mathrm{O}\right) \mathrm{H}\right]\left(\mathrm{PF}_{6}\right)_{5} \bullet\left(\mathrm{CH}_{3} \mathrm{CN}\right)_{3}\left(\mathrm{CH}_{2} \mathrm{Cl}_{2}\right)_{3}$, $\mathrm{C}_{45} \mathrm{H}_{88} \mathrm{Cl}_{6} \mathrm{Cu}_{3} \mathrm{~F}_{30} \mathrm{~N}_{19} \mathrm{OP}_{5}$ : C, 26.50; H, 4.35; N, 13.05. found C, 26.83; H, 4.15; N, 12.98 .
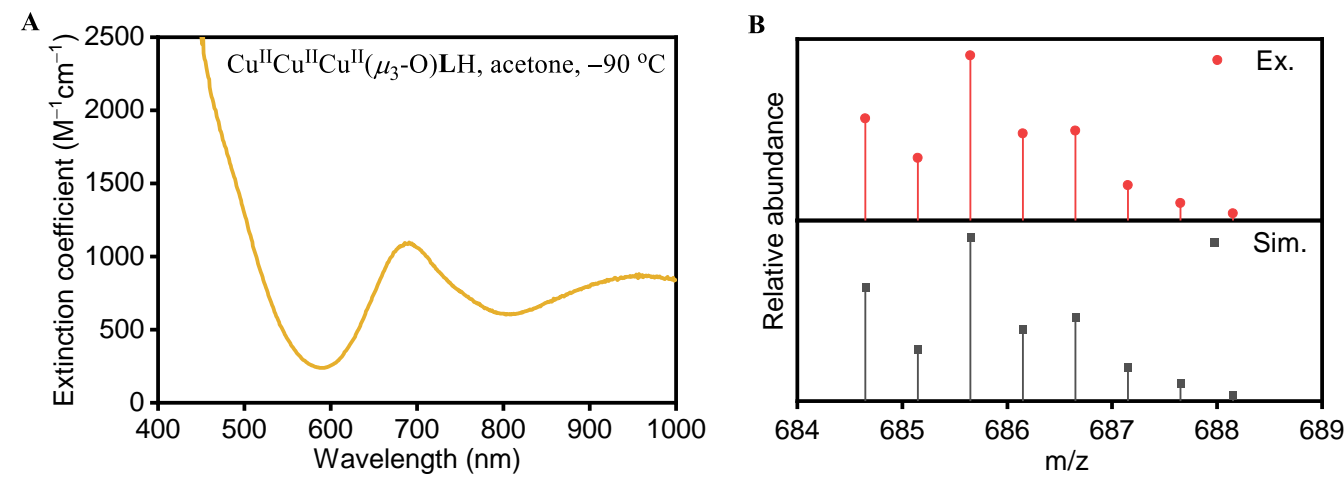

Figure S1. (A) UV-Vis spectrum of $\left[\mathrm{Cu}^{\mathrm{II}} \mathrm{Cu}^{\mathrm{II}} \mathrm{Cu}^{\mathrm{II}}\left(\mu_{3}-\mathrm{O}\right) \mathbf{L} \mathbf{H}\right]\left(\mathrm{PF}_{6}\right)_{5}$ at $-90{ }^{\circ} \mathrm{C}$ in acetone. (B) ESI-MS spectrum $(\mathrm{MeCN})$ and simulation of $\left[\mathrm{Cu}^{\mathrm{II}} \mathrm{Cu}^{\mathrm{II}} \mathrm{Cu}^{\mathrm{II}}\left(\mu_{3}-\mathrm{O}\right) \mathbf{L H}\left(\mathrm{PF}_{6}\right)_{3}\right]^{2+}$

\section{Synthesis and characterization of $\left[\mathrm{TREN}_{4} \mathrm{Cu}^{\mathrm{I}} \mathrm{Cu}^{\mathrm{I}} \mathrm{Cu}^{\mathrm{I}}\left(\mu_{2}-\mathrm{OH}_{2}\right)\right]\left(\mathrm{BAr}^{\mathrm{F}}\right)_{3}\left(\mathrm{Cu}^{\mathrm{I}} \mathrm{Cu}^{\mathrm{I}} \mathrm{Cu}^{\mathrm{I}}\left(\mu_{2^{-}}\right.\right.$ $\left.\left.\mathrm{OH}_{2}\right) \mathrm{L}\right)$}

$$
\left[\operatorname{TREN}_{4} \mathrm{Cu}^{\prime} \mathrm{Cu}^{\prime} \mathrm{Cu}\left(\mu_{3}-\mathrm{OH}\right)\right]\left(\mathrm{BAr}_{4}{ }_{4}\right)_{2} \frac{\left.1.5 \mathrm{eq}^{2}\left(\mathrm{Et}_{2} \mathrm{O}\right)_{2} \mathrm{H}\right] \mathrm{BAr}_{4}}{\mathrm{THF}, \text { r.t. }}\left[\operatorname{TREN}_{4} \mathrm{Cu}^{\prime} \mathrm{Cu}^{\prime} \mathrm{Cu}^{\prime}\left(\mu_{2}-\mathrm{OH}_{2}\right)\right]\left(\mathrm{BAr}_{4}\right)_{3}
$$

Yield: $73 \%$

To a THF solution of $\left[\mathbf{T R E N}_{4} \mathrm{Cu}^{\mathrm{I}} \mathrm{Cu}^{\mathrm{I}} \mathrm{Cu}^{\mathrm{I}}\left(\mu_{3}-\mathrm{OH}\right)\right]\left(\mathrm{BAr}_{4}\right)_{2}(20 \mathrm{mg}, 0.0075 \mathrm{mmol})$, a THF solution of $\left[\left(\mathrm{Et}_{2} \mathrm{O}\right)_{2} \mathrm{H}\right] \mathrm{BAr}_{4}{ }_{4}(10.5 \mathrm{mg}, 0.0105 \mathrm{mmol})$ was added under $\mathrm{N}_{2}$ atmosphere. After stirring for $10 \mathrm{~min}$. All volatiles were removed under vacuum. The obtained colorless solid was washed with diethyl ether (ca. $2 \mathrm{~mL}$ ) and dried under vacuum (19 mg, yield: 73\%).

In order to obtain single crystals for X-ray diffraction analysis, a counter anion exchange was performed. [ $\left.\mathbf{T R E N}_{4} \mathrm{Cu}^{\mathrm{I}} \mathrm{Cu}^{\mathrm{I}} \mathrm{Cu}^{\mathrm{I}}\left(\mu_{3}-\mathrm{OH}\right)\right]\left(\mathrm{BAr}^{\mathrm{F}}{ }_{4}\right)_{2}$ product obtained from the previous step (19 $\mathrm{mg}$ ) was redissolved in THF (ca. $1 \mathrm{~mL}$ ) and slowly added to a THF solution (ca. $2 \mathrm{~mL}$ ) of 
$\mathrm{TBAPF}_{6}(11.6 \mathrm{mg}, 0.030 \mathrm{mmol})$ with stirring. A suspension formed immediately and the white precipitate was collected by filtration, washed with THF (ca. $2 \mathrm{~mL}$ ), dried under vacuum, and dissolved in acetone (ca.1 mL). Diethyl ether was allowed to slowly diffuse into the acetone solution obtained above, and light-blue crystals suitable for single-crystal X-ray diffraction formed after two days. ${ }^{1} \mathrm{H}$ NMR (600 MHz, THF- $d_{8}$, Figure S3) $\delta 9.15(\mathrm{~s}, 2 \mathrm{H}), 7.78(\mathrm{br}, 24 \mathrm{H})$, 7.57 (br, 12H), 4.12-3.86 (m, 12H), 3.25-3.08 (br, 12H), 3.07-2.93 (br, 12H), 2.88 (d, 3H), 2.73 $(\mathrm{d}, 3 \mathrm{H}), 2.69-2.46(\mathrm{br}, 24 \mathrm{H}), 2.31(\mathrm{~d}, 3 \mathrm{H}), 2.13(\mathrm{~d}, 3 \mathrm{H})$; Infrared spectrum (ATR), no signal was observed for $\mathrm{X}-\mathrm{H}(\mathrm{X}=\mathrm{N}, \mathrm{O})$ stretches due to hydrogen bonding induced broadening; UV-vis spectrum (THF, Figure S2A), $\lambda_{\max }=320 \mathrm{~nm}\left(1850 \mathrm{M}^{-1} \mathrm{~cm}^{-1}\right)$; ESI-MS spectrum (Figure S2B), [TREN $\left.{ }_{4} \mathrm{Cu}^{\mathrm{I}} \mathrm{Cu}^{\mathrm{I}} \mathrm{Cu}^{\mathrm{I}}\left(\mu_{2}-\mathrm{OH}_{2}\right)\right]^{3+}\left(\mathrm{C}_{36} \mathrm{H}_{74} \mathrm{Cu}_{3} \mathrm{~N}_{16} \mathrm{O}^{3+}\right) \mathrm{M} / \mathrm{z}=312.5$; FT-IR spectrum (Figure S2C). Elemental analysis, Calcd for $\mathrm{C}_{132} \mathrm{H}_{109} \mathrm{~B}_{3} \mathrm{Cu}_{3} \mathrm{~F}_{72} \mathrm{~N}_{16} \mathrm{O}: \mathrm{C}, 44.96 ; \mathrm{H}, 3.12 ; \mathrm{N}, 6.36$. found $\mathrm{C}$, 44.73; H, 2.93; N, 5.95.
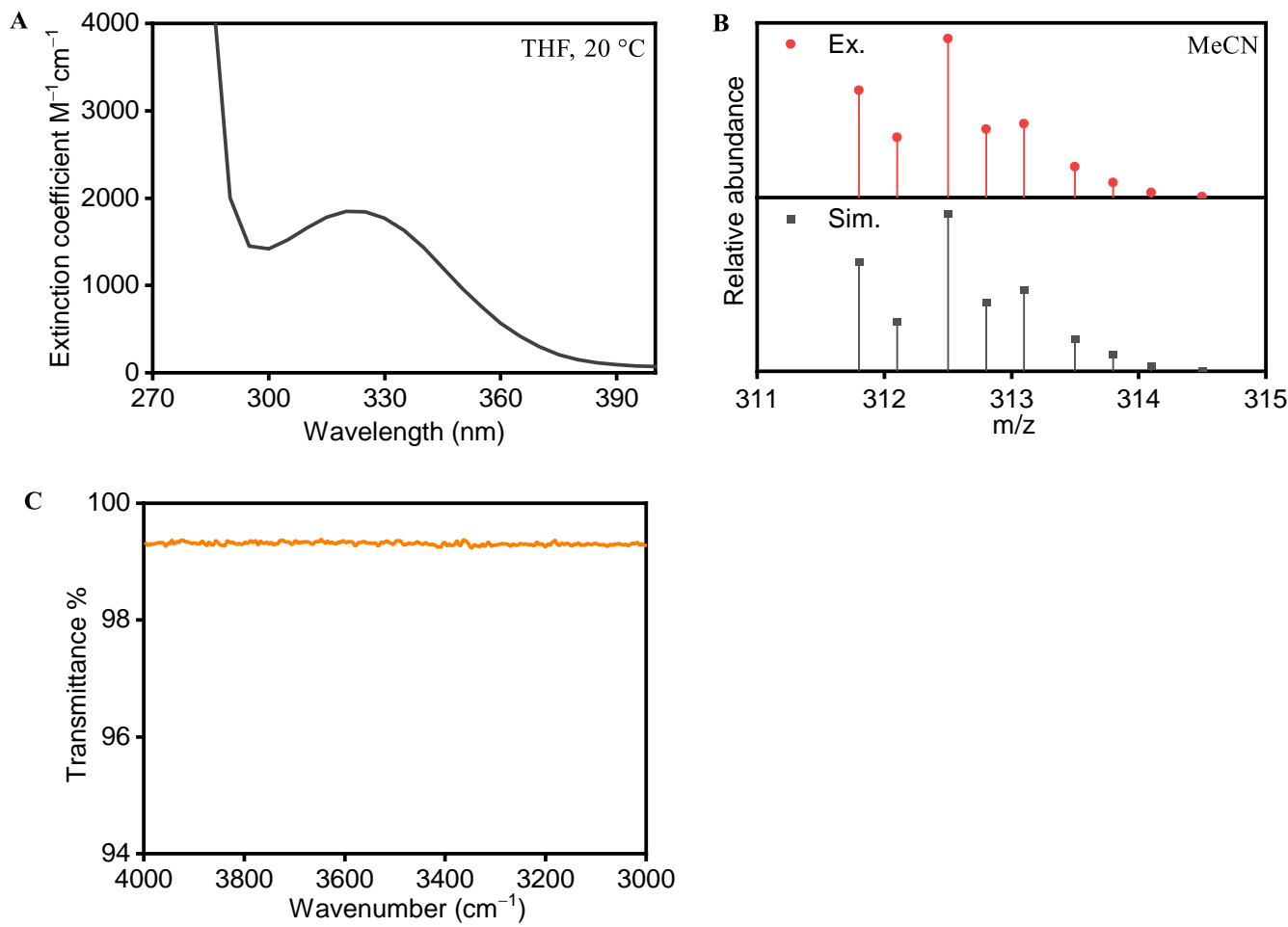

Figure S2. (A) UV-Vis spectrum of $\left[\mathbf{T R E N}_{4} \mathrm{Cu}^{\mathrm{I}} \mathrm{Cu}^{\mathrm{I}} \mathrm{Cu}^{\mathrm{I}}\left(\mu_{2}-\mathrm{OH}_{2}\right)\right]\left(\mathrm{BAr}_{4}\right)_{3}$ at $20^{\circ} \mathrm{C}$ in THF. (B) ESI-MS of [TREN $\left.{ }_{4} \mathrm{Cu}^{\mathrm{I}} \mathrm{Cu}^{\mathrm{I}} \mathrm{Cu}^{\mathrm{I}}\left(\mu_{2}-\mathrm{OH}_{2}\right)\right]\left(\mathrm{BAr}_{4}^{\mathrm{F}}\right)_{3}$ in $\mathrm{MeCN}$ at $20^{\circ} \mathrm{C}$. (C) FT-IR spectrum of $\left[\operatorname{TREN}_{4} \mathrm{Cu}^{\mathrm{I}} \mathrm{Cu}^{\mathrm{I}} \mathrm{Cu}^{\mathrm{I}}\left(\mu_{2}-\mathrm{OH}_{2}\right)\right]\left(\mathrm{BAr}^{\mathrm{F}}\right)_{3}$ from 4000 to $3000 \mathrm{~cm}^{-1}$. 
A

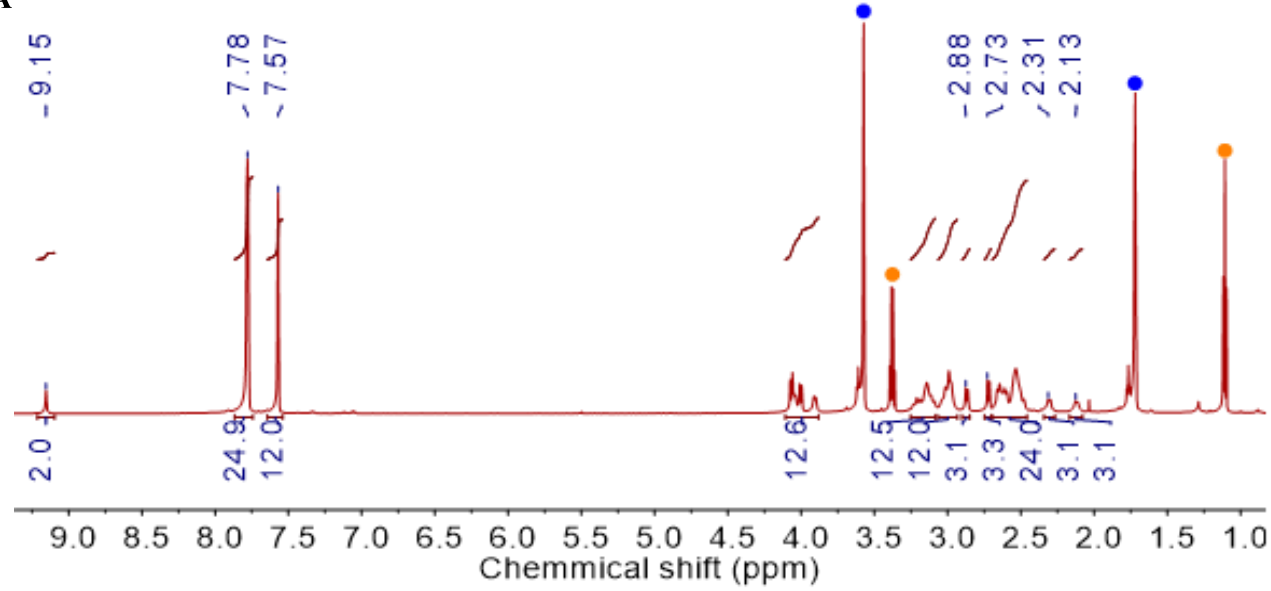

B

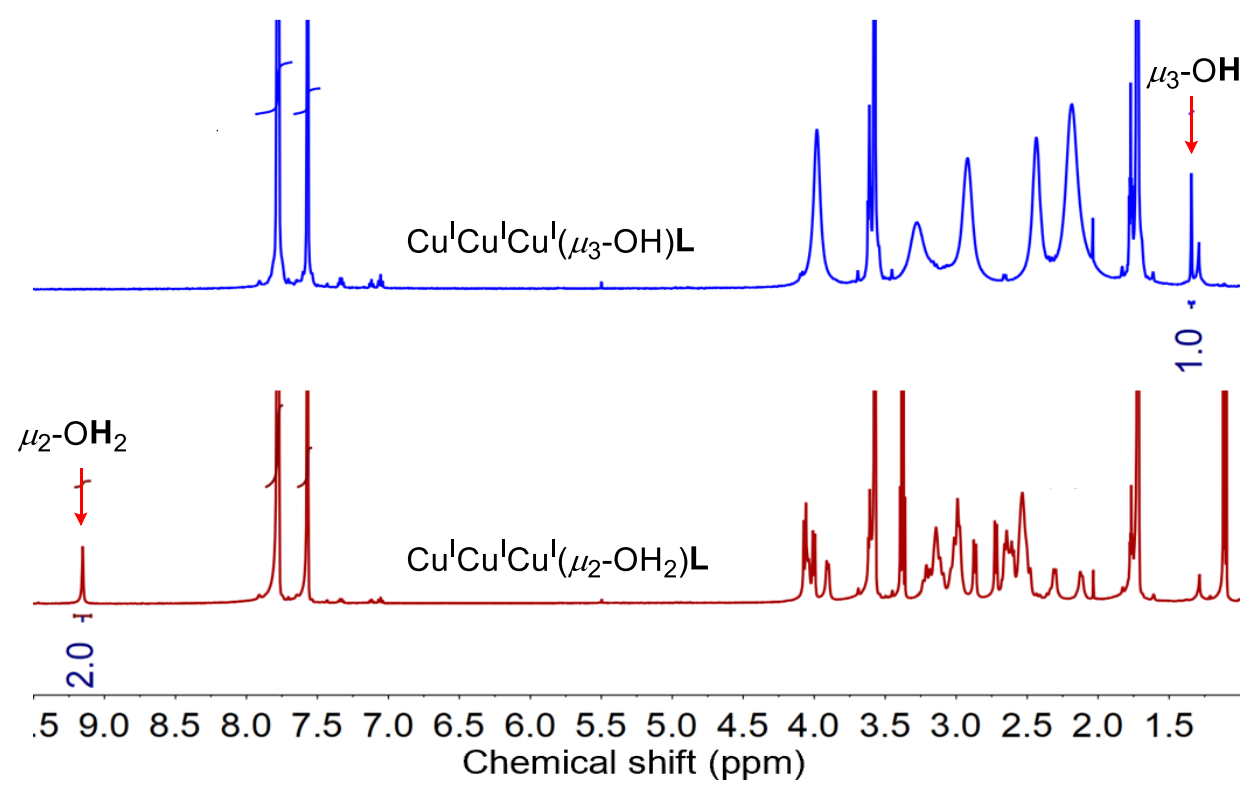

Figure S3. (A) ${ }^{1} \mathrm{H}$ NMR of $\left[\operatorname{TREN}_{4} \mathrm{Cu}^{\mathrm{I}} \mathrm{Cu}^{\mathrm{I}} \mathrm{Cu}^{\mathrm{I}}\left(\mu_{2}-\mathrm{OH}_{2}\right)\right]\left(\mathrm{BAr}^{\mathrm{F}}\right)_{3}\left(600 \mathrm{MHz}, \mathrm{THF}-d_{8}\right)$. The peaks marked with blue dots are from residual THF. The peaks marked with green spots are from residual diethyl ether. (B) ${ }^{1} \mathrm{H}$ NMR spectra of $\mathrm{Cu}^{\mathrm{I}} \mathrm{Cu}^{\mathrm{I}} \mathrm{Cu}^{\mathrm{I}}\left(\mu_{3}-\mathrm{OH}\right) \mathbf{L}$ (THF- $d_{8}, 600$ $\mathrm{MHz}$ ) before (blue) and after (red) protonation.

\section{Synthesis and characterization of $\left[\left(\mathrm{Et}_{2} \mathrm{O}\right)_{2} \mathrm{D}_{\mathrm{BAAr}}{ }_{4}\right.$}

$$
\underset{1 \mathrm{Na} \mathrm{BArF}}{4}+\underset{18 \mathrm{eq}}{\mathrm{DCl}} \stackrel{-78{ }^{\circ} \mathrm{C}}{\stackrel{\mathrm{Et}_{2} \mathrm{O}}{\longrightarrow}}\left[\left(\mathrm{Et}_{2} \mathrm{O}\right)_{2} \mathrm{D} \mathrm{BArF}_{4}+\mathrm{NaCl} \downarrow\right.
$$

$\mathrm{Na} \mathrm{BAr}{ }_{4}$ (100 mg, $\left.0.113 \mathrm{mmol}\right)$ was dissolved in diethyl ether $(2 \mathrm{~mL})$, and the solution was allowed to store over $4 \AA$ molecular sieves for 12 hours in the glovebox. Then the diethyl ether solution was transferred to a $10-\mathrm{mL}$ Schlenk flask and the Schlenk flask was transferred outside the glovebox and cooled in dry-ice-acetone cold bath. Under $\mathrm{N}_{2}$ protection, a diethyl ether 
solution of deuterium chloride ( $2 \mathrm{~mL}, 2 \mathrm{mmol})$ was injected into the Schlenk flask with a 3-mL syringe. The mixture was allowed to stir in dry-ice-acetone cold bath for two hours. Then the obtained suspension was transferred to the glovebox. After filtration, the pale yellow filtrate was concentrated under vacuum till the solid started to form. After pipetting out the yellow solution, the solid was dried under high vacuum, and a colorless solid was obtained (53 $\mathrm{mg}$, $46.3 \%$ ). ${ }^{1} \mathrm{H}$ NMR (600 MHz, THF- $d_{8}$, Figure S4) $\delta 7.82$ (br, 8H), 7.61 (br, 4H), 3.42 (q, 8H), $1.15(\mathrm{t}, 12 \mathrm{H})$. Elemental analysis, Calcd for $\mathrm{C}_{40} \mathrm{H}_{32} \mathrm{DBF}_{24} \mathrm{O}_{2}: \mathrm{C}, 47.40 ; \mathrm{H}, 3.38$. found $\mathrm{C}, 47.73$; $\mathrm{H}, 3.50$.

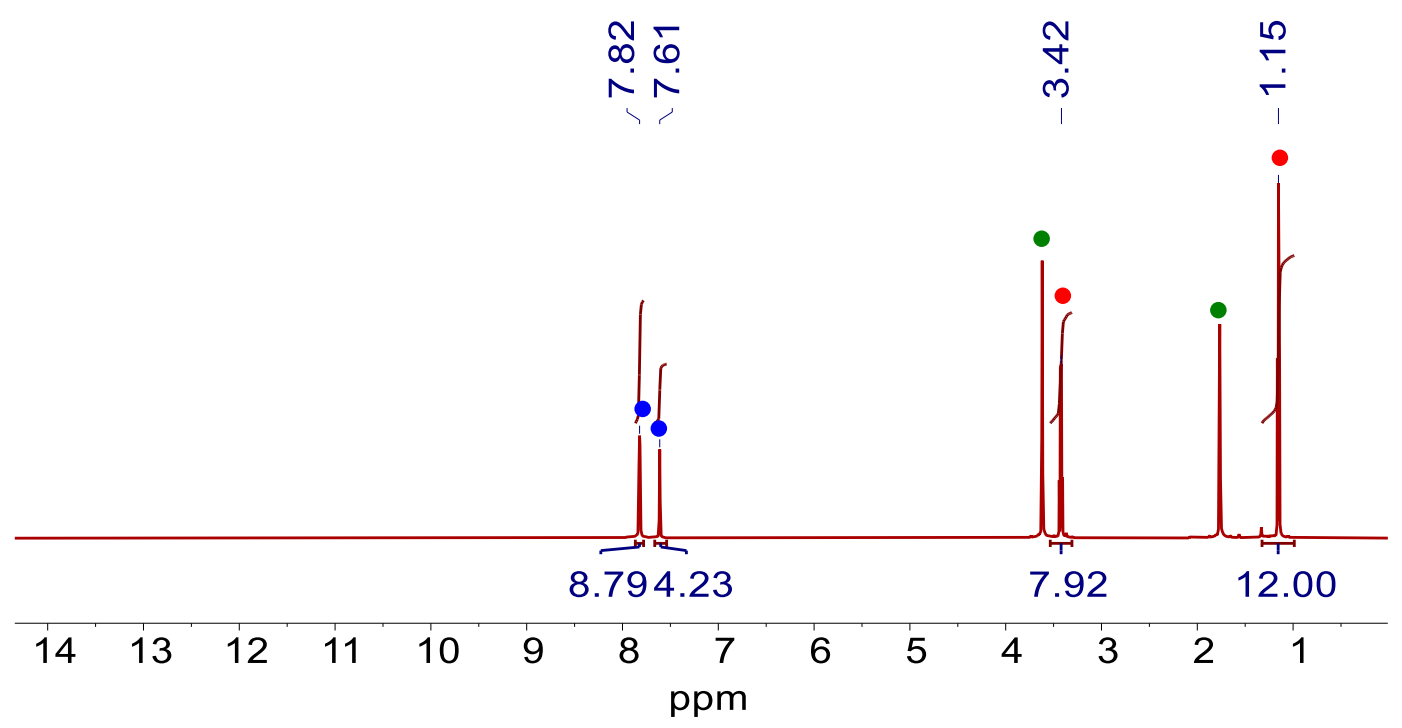

Figure S4. ${ }^{1} \mathrm{H}$ NMR of $\left[\left(\mathrm{Et}_{2} \mathrm{O}\right)_{2} \mathrm{D}\right] \mathrm{BAr}{ }_{4}{ }_{4}$ in THF- $d_{8}(600 \mathrm{MHz})$. Peaks marked with blue dots are from $\mathrm{BAr}_{4} \mathrm{~F}_{4}$ anion and the peaks marked with red dots are from diethyl ether. The solvent peaks for THF- $d_{8}$ are marked with green dots. 


\section{UV-Vis spectroscopy and kinetic simulation details}

\section{Kinetic study of the reaction between $\mathrm{Cu}^{\mathrm{I}} \mathrm{Cu}^{\mathrm{I}} \mathrm{Cu}^{\mathrm{I}}\left(\mu_{3}-\mathrm{OH}\right) \mathrm{L}$ and $\left[\left(\mathrm{Et}_{2} \mathrm{O}\right)_{2} \mathrm{H}\right] \mathrm{BAr}^{\mathrm{F}}{ }_{4}$}

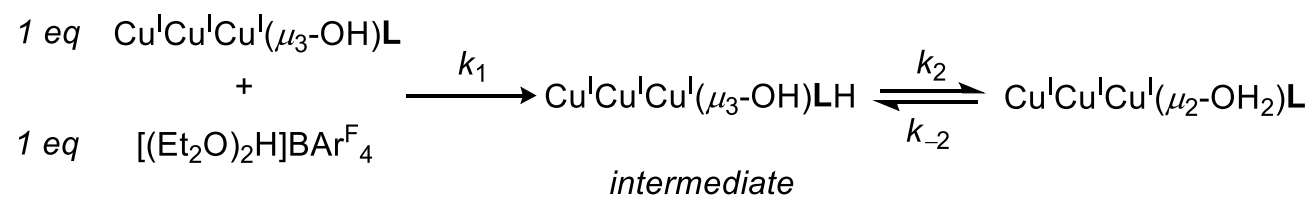

In glovebox, a THF solution $(2 \mathrm{~mL})$ of $\left[\mathrm{Cu}^{\mathrm{I}} \mathrm{Cu}^{\mathrm{I}} \mathrm{Cu}^{\mathrm{I}}\left(\mu_{3}-\mathrm{OH}\right) \mathbf{L}\right]\left(\mathrm{BAr}_{4}\right)_{2}(4 \mathrm{mg}, 1.5 \mu \mathrm{mol})$ was transferred to a quartz cuvette equipped with a septum under $\mathrm{N}_{2}$. The cuvette was sealed and transferred to the UV-Vis spectrometer. Under nitrogen protection, a THF solution $(0.1 \mathrm{~mL})$ of $\left[\left(\mathrm{Et}_{2} \mathrm{O}\right)_{2} \mathrm{H}\right] \mathrm{BAr}_{4}{ }_{4}(1.5 \mathrm{mg}, 1.5 \mu \mathrm{mol})$ was injected into the cuvette by a $1-\mathrm{mL}$ syringe with vigorous stirring. The progress of the reaction was monitored with $\mathrm{UV}$-vis at $0{ }^{\circ} \mathrm{C}(30 \mathrm{~s}$ interval), $10{ }^{\circ} \mathrm{C}$ (15 s interval), $20{ }^{\circ} \mathrm{C}\left(6 \mathrm{~s}\right.$ interval), and $30{ }^{\circ} \mathrm{C}(3 \mathrm{~s}$ interval), respectively (Figure S5). The UV-vis spectra of the reaction were deconvoluted into $\mathrm{Cu}^{\mathrm{I}} \mathrm{Cu}^{\mathrm{I}} \mathrm{Cu}^{\mathrm{I}}\left(\mu_{3}-\mathrm{OH}\right) \mathbf{L}, \mathrm{Cu}^{\mathrm{I}} \mathrm{Cu}^{\mathrm{I}} \mathrm{Cu}^{\mathrm{I}}\left(\mu_{3}-\right.$

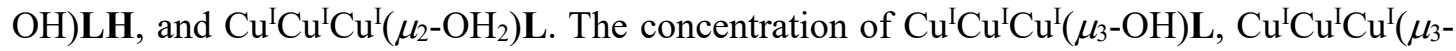

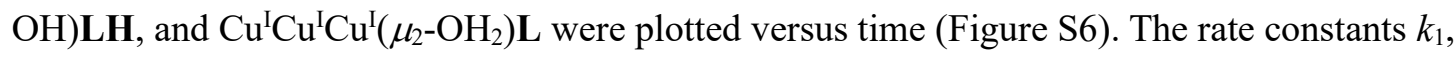
$k_{2}$, and $k_{-2}$ were simulated with the software KinTek Explorer. ${ }^{5,6}$
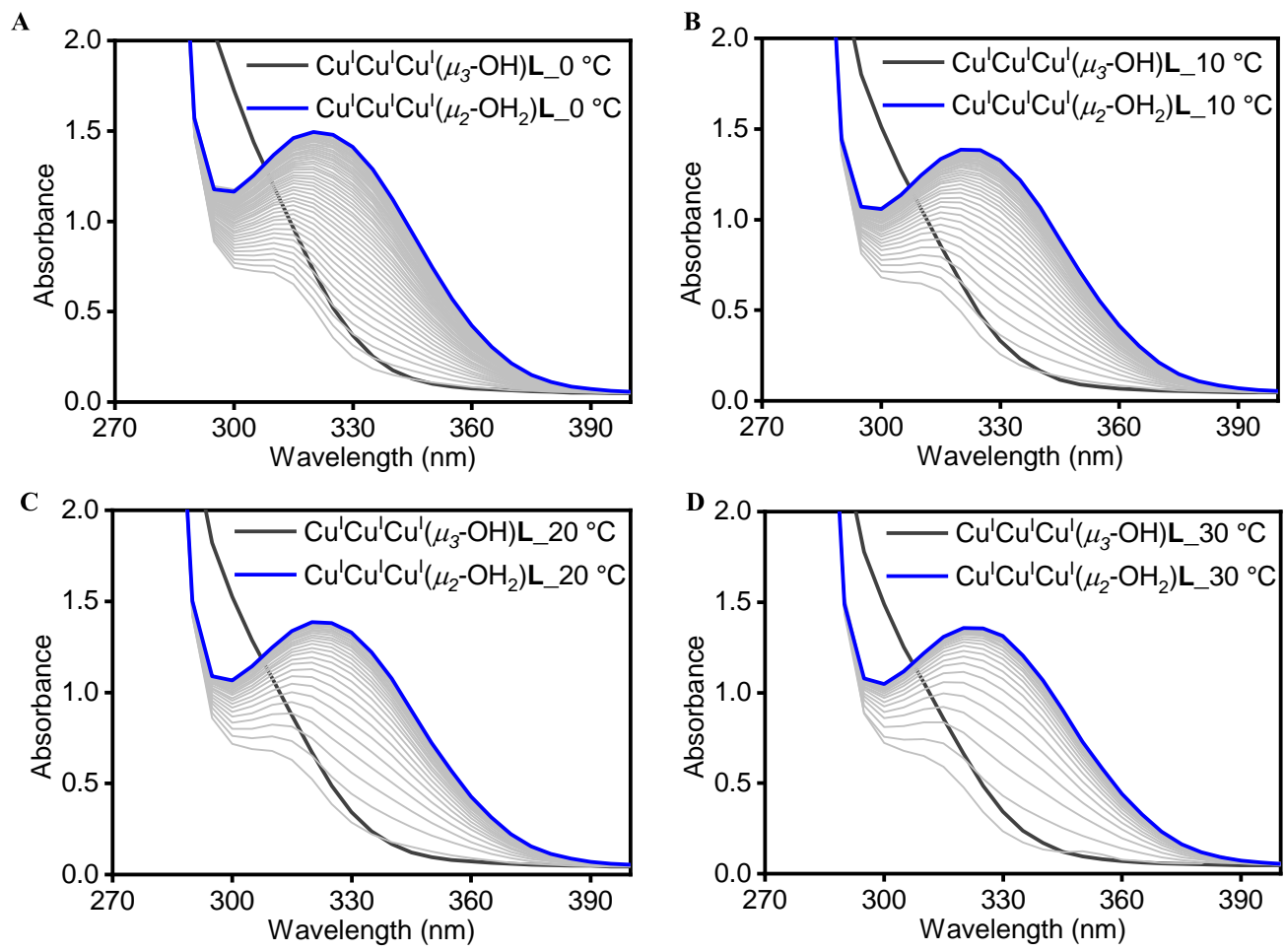

Figure S5. UV-vis spectrum of the reaction between $\mathrm{Cu}^{\mathrm{I}} \mathrm{Cu}^{\mathrm{I}} \mathrm{Cu}^{\mathrm{I}}\left(\mu_{3}-\mathrm{OH}\right) \mathbf{L}$ and $\left[\left(\mathrm{Et}_{2} \mathrm{O}\right)_{2} \mathrm{H}\right] \mathrm{BAr}{ }_{4} \mathrm{~F}_{4} \mathrm{THF}$ at $(\mathrm{A}) 0^{\circ} \mathrm{C}$, (B) $10{ }^{\circ} \mathrm{C}$, (C) $20^{\circ} \mathrm{C}$, and (D) $30^{\circ} \mathrm{C}$. 

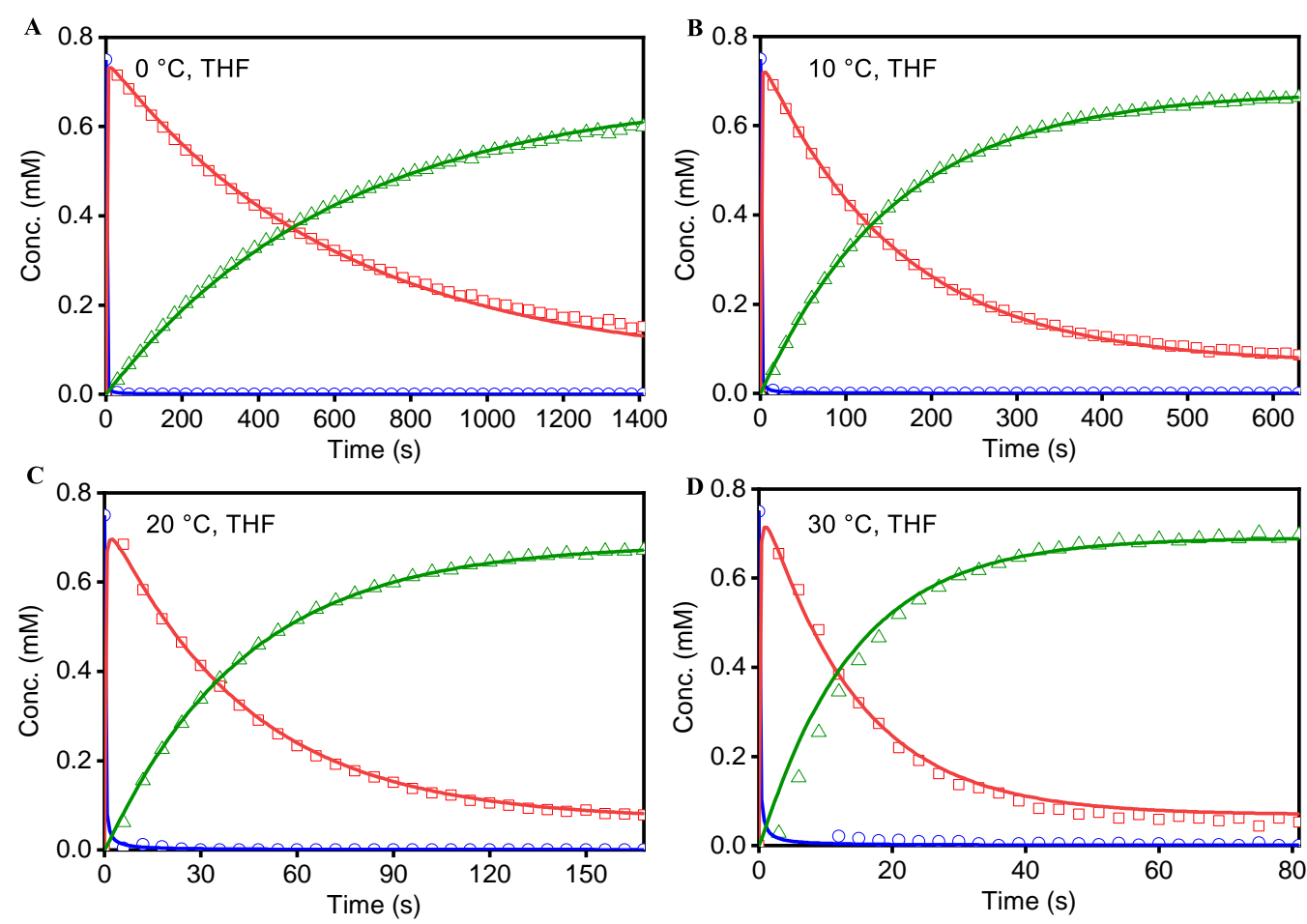

Figure S6. Kinetic simulation at (A) $0{ }^{\circ} \mathrm{C}$, (B) $10{ }^{\circ} \mathrm{C}$, (C) $20{ }^{\circ} \mathrm{C}$, and (D) $30{ }^{\circ} \mathrm{C}$. $\mathrm{Cu}^{\mathrm{I}} \mathrm{Cu}^{\mathrm{I}} \mathrm{Cu}^{\mathrm{I}}\left(\mu_{3}-\mathrm{OH}\right) \mathbf{L}$ (green circle: experiment data; green line: simulated data). $\mathrm{Cu}^{\mathrm{I}} \mathrm{Cu}^{\mathrm{I}} \mathrm{Cu}^{\mathrm{I}}\left(\mu_{3}-\mathrm{OH}\right) \mathbf{L H}$ (red square: experiment data; red line: simulated data). $\mathrm{Cu}^{\mathrm{I}} \mathrm{Cu}^{\mathrm{I}} \mathrm{Cu}^{\mathrm{I}}\left(\mu_{2}-\mathrm{OH}_{2}\right) \mathbf{L}$ (blue triangle: experiment data; blue line: simulated data). The $K_{\mathrm{eq}}=$ $k_{2} / k_{-2}$ are locked to $8.5\left(30^{\circ} \mathrm{C}\right), 9.1\left(20^{\circ} \mathrm{C}\right), 9.8\left(10^{\circ} \mathrm{C}\right)$, and $10.7\left(0^{\circ} \mathrm{C}\right)$ according to $\mathrm{CV}$ simulation (See below)

\begin{tabular}{cccccc}
$\begin{array}{c}\text { Temperature } \\
\left({ }^{\circ} \mathrm{C}\right)\end{array}$ & & $\mathbf{0}$ & $\mathbf{1 0}$ & $\mathbf{2 0}$ & \multicolumn{2}{c}{$\mathbf{3 0}$} \\
\hline & lower & $1.1 \times 10^{4}$ & $1.2 \times 10^{4}$ & $1.4 \times 10^{4}$ & $5.7 \times 10^{3}$ \\
$k_{1}$ & Best fit & $1.4 \times 10^{4}$ & $1.5 \times 10^{4}$ & $1.9 \times 10^{4}$ & $2.1 \times 10^{4}$ \\
$\left(\mathrm{M}^{-1} \mathrm{~s}^{-1}\right)$ & upper & $3.5 \times 10^{4}$ & $1.9 \times 10^{4}$ & $4.6 \times 10^{4}$ & $1.8 \times 10^{5}$ \\
& lower & $1.5 \times 10^{-3}$ & $5.6 \times 10^{-3}$ & $2.2 \times 10^{-2}$ & $6.7 \times 10^{-2}$ \\
$k_{2}$ & Best fit & $1.5 \times 10^{-3}$ & $5.8 \times 10^{-3}$ & $2.2 \times 10^{-2}$ & $6.9 \times 10^{-2}$ \\
$\left(\mathrm{~s}^{-1}\right)$ & upper & $1.5 \times 10^{-3}$ & $6.0 \times 10^{-3}$ & $2.2 \times 10^{-2}$ & $7.5 \times 10^{-2}$ \\
& lower & - & - & - & - \\
$k_{-2}$ & Best fit & $1.4 \times 10^{-4} \mathrm{a}$ & $5.6 \times 10^{-4} \mathrm{a}$ & $2.4 \times 10^{-3} \mathrm{a}$ & $8.1 \times 10^{-3} \mathrm{a}$ \\
$\left(\mathrm{s}^{-1}\right)$ & upper & - & - & - & - \\
\hline
\end{tabular}

Table S1: Summary of rate constants from kinetic simulation for the reaction reaction between $\mathrm{Cu}^{\mathrm{I}} \mathrm{Cu}^{\mathrm{I}} \mathrm{Cu}^{\mathrm{I}}\left(\mu_{3}-\mathrm{OH}\right) \mathbf{L}$ and $\left[\left(\mathrm{Et}_{2} \mathrm{O}\right)_{2} \mathrm{H}\right] \mathrm{BAr}_{4}^{\mathrm{F}}$. The upper and lower limits for rate constant were derived from the threshold of $\mathrm{Chi}^{2}{ }_{\text {min }} / \mathrm{Chi}^{2}=0.9{ }^{\mathrm{a}}{ }^{\mathrm{a}}$ : values that are dependant with $k_{2}$. The values of $k_{-2}$ at different temperature are dependant with $k_{2}$ from the estimated $K_{\text {eq }}=k_{2} / k_{-2}$ from CV simulation (see section 7). The extended $K_{\text {eq }}$ at different temperature are derived from the equation $\Delta G=-R T \ln K_{e q}$. 
Determining the rate law of the reaction between $\mathrm{Cu}^{\mathrm{I}} \mathrm{Cu}^{\mathrm{I}} \mathrm{Cu}^{\mathrm{I}}\left(\mu_{3}-\mathrm{OH}\right) \mathrm{L}$ and $\left[\left(\mathbf{E t}_{2} \mathbf{O}\right)_{2} \mathbf{H}\right] \mathrm{BAr}^{\mathrm{F}_{4}}$

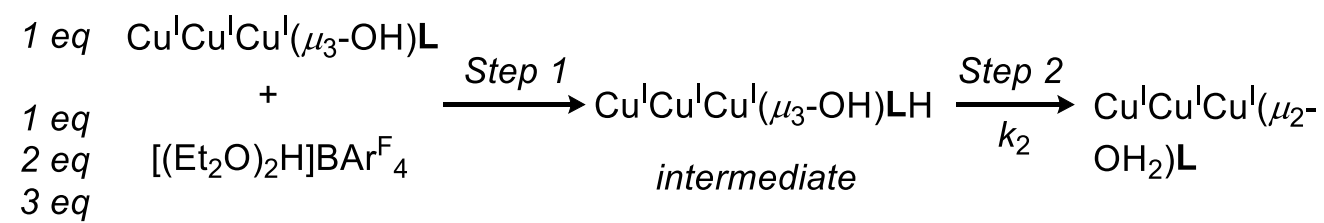

In glovebox, a THF solution $(2 \mathrm{~mL})$ of $\left[\mathrm{Cu}^{\mathrm{I}} \mathrm{Cu}^{\mathrm{I}} \mathrm{Cu}^{\mathrm{I}}\left(\mu_{3}-\mathrm{OH}\right) \mathbf{L}\right]\left(\mathrm{BAr}^{\mathrm{F}}\right)_{2}(4 \mathrm{mg}, 1.5 \mu \mathrm{mol})$ was transferred to a quartz cuvette equipped with a septum under $\mathrm{N}_{2}$. The cuvette was sealed and transferred to the UV-Vis spectrometer. Under nitrogen protection, a THF solution $(0.1 \mathrm{~mL})$ of $\left[\left(\mathrm{Et}_{2} \mathrm{O}\right)_{2} \mathrm{H}\right] \mathrm{BAr}_{4}{ }_{4}(1.5 \mathrm{mg}$ for $1 \mathrm{eq}, 3.0 \mathrm{mg}$ for $2 \mathrm{eq}$, and $4.5 \mathrm{mg}$ for $3 \mathrm{eq}$ with respect to $\left.\mathrm{Cu}^{\mathrm{I}} \mathrm{Cu}^{\mathrm{I}} \mathrm{Cu}^{\mathrm{I}}\left(\mu_{3}-\mathrm{OH}\right) \mathbf{L}\right)$ was injected into the cuvette by a $1-\mathrm{mL}$ syringe with vigorous stirring. The progress of the reaction was monitored with UV-vis at $20^{\circ} \mathrm{C}(1.8 \mathrm{~s}$ interval). The UV-vis spectra of the reaction were deconvoluted into $\mathrm{Cu}^{\mathrm{I}} \mathrm{Cu}^{\mathrm{I}} \mathrm{Cu}^{\mathrm{I}}\left(\mu_{3}-\mathrm{OH}\right) \mathbf{L}, \mathrm{Cu}^{\mathrm{I}} \mathrm{Cu}^{\mathrm{I}} \mathrm{Cu}^{\mathrm{I}}\left(\mu_{3}-\mathrm{OH}\right) \mathbf{L H}$, and $\mathrm{Cu}^{\mathrm{I}} \mathrm{Cu}^{\mathrm{I}} \mathrm{Cu}^{\mathrm{I}}\left(\mu_{2}-\mathrm{OH}_{2}\right) \mathbf{L}$. The concentration of $\mathrm{Cu}^{\mathrm{I}} \mathrm{Cu}^{\mathrm{I}} \mathrm{Cu}^{\mathrm{I}}\left(\mu_{3}-\mathrm{OH}\right) \mathbf{L H}$ was plotted versus time (Figure S7A) to investigate the rate law for Step 2. According to the plot of $\ln \left[\mathrm{Cu}^{\mathrm{I}} \mathrm{Cu}^{\mathrm{I}} \mathrm{Cu}^{\mathrm{I}}\left(\mu_{3}-\right.\right.$ $\mathrm{OH}) \mathbf{L H}$ ] versus time (Figure S7B), Step 2 follows the first-order rate law very well, and the rate of Step 2 is independent of the concentration of $\left[\left(\mathrm{Et}_{2} \mathrm{O}\right)_{2} \mathrm{H}\right] \mathrm{Bar}_{4}{ }_{4}$ (Figure S7C).
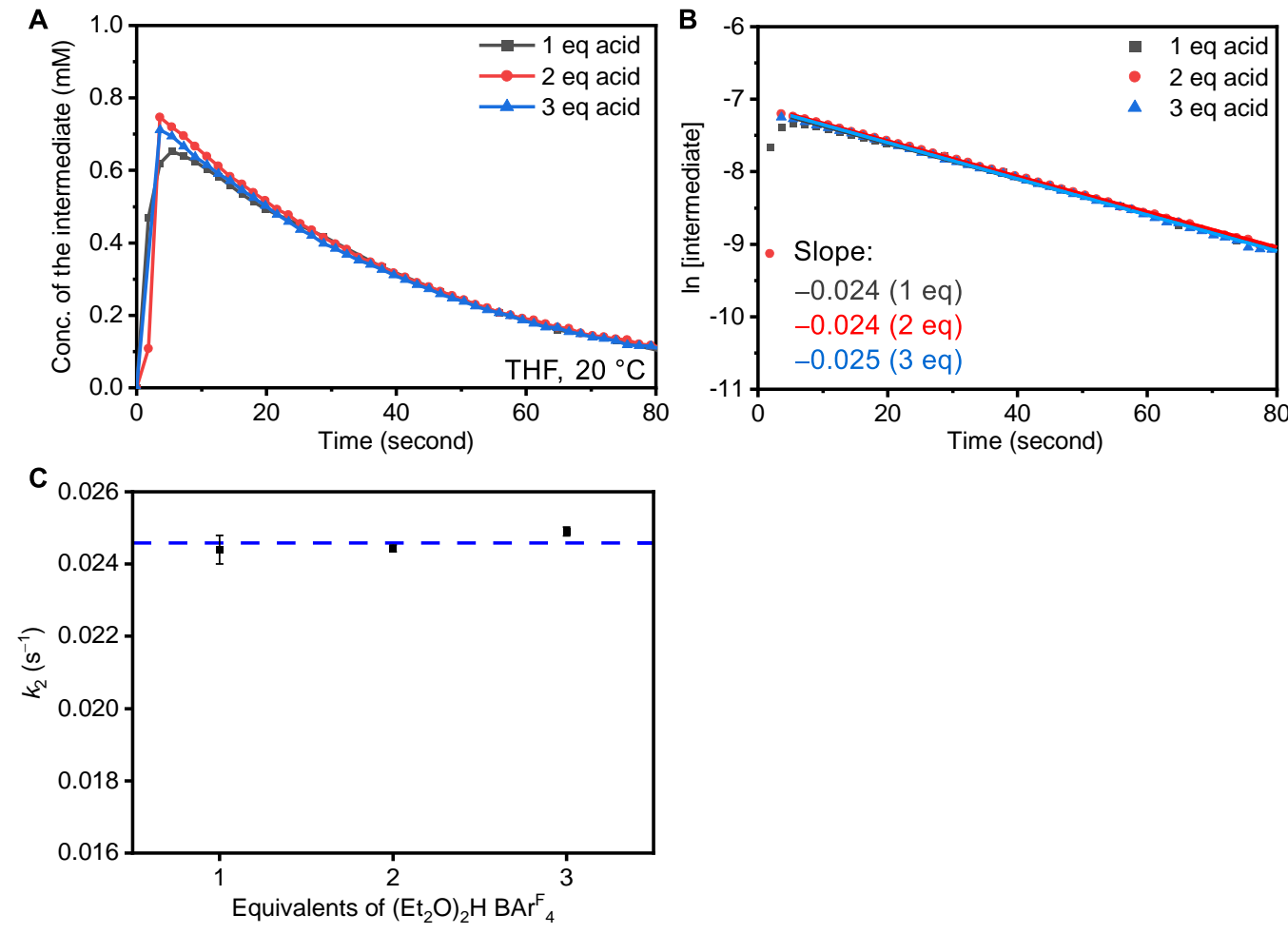

Figure S7. (A) Plots of concentration of the intermediate $\mathrm{Cu}^{\mathrm{I}} \mathrm{Cu}^{\mathrm{I}} \mathrm{Cu}^{\mathrm{I}}\left(\mu_{3}-\mathrm{OH}\right) \mathbf{L H}$ versus time during the reaction of $\mathrm{Cu}^{\mathrm{I}} \mathrm{Cu}^{\mathrm{I}} \mathrm{Cu}^{\mathrm{I}}\left(\mu_{3}-\mathrm{OH}\right) \mathbf{L}$ and $\left[\left(\mathrm{Et}_{2} \mathrm{O}\right)_{2} \mathrm{H}\right] \mathrm{BAr}{ }_{4}$. (B) First-order rate law plot for Step 2. The data spots from the first 3.6 seconds were not included for plotting due to the imcompletion of step 1. (C) Summary of the first order rate constant for Step 2 with different equivalents of $\left[\left(\mathrm{Et}_{2} \mathrm{O}\right)_{2} \mathrm{H}\right] \mathrm{BAr}{ }_{4}$. 


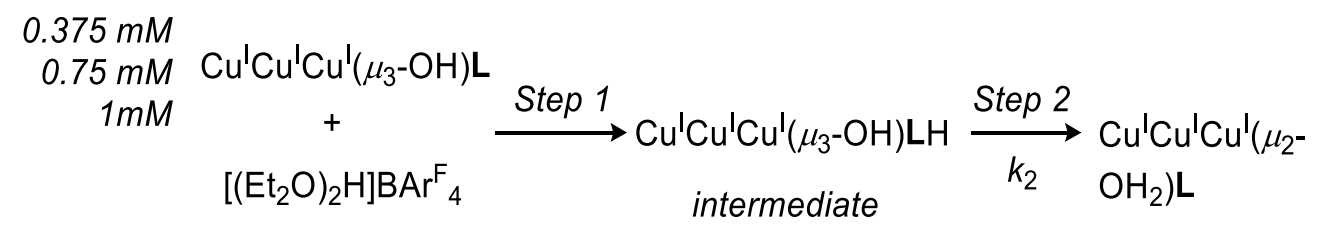

In glovebox, a THF solution $(2 \mathrm{~mL})$ of $\left[\mathrm{Cu}^{\mathrm{I}} \mathrm{Cu}^{\mathrm{I}} \mathrm{Cu}^{\mathrm{I}}\left(\mu_{3}-\mathrm{OH}\right) \mathbf{L}\right]\left(\mathrm{BAr}^{\mathrm{F}}\right)_{2}(2 \mathrm{mg}$ for $0.375 \mathrm{mM}, 4$ $\mathrm{mg}$ for $0.75 \mathrm{mM}, 5.3 \mathrm{mg}$ for $1 \mathrm{mM}$ ) was transferred to a quartz cuvette equipped with a septum under $\mathrm{N}_{2}$. The cuvette was sealed and transferred to the UV-Vis spectrometer. Under nitrogen protection, a THF solution $(0.1 \mathrm{~mL})$ of $\left[\left(\mathrm{Et}_{2} \mathrm{O}\right)_{2} \mathrm{H}\right] \mathrm{BAr}_{4}(2.0 \mathrm{mg}, 2.0 \mu \mathrm{mol})$ was injected into the cuvette by a $1-\mathrm{mL}$ syringe with vigorous stirring. The progress of the reaction was monitored with UV-vis at $20{ }^{\circ} \mathrm{C}(1.8 \mathrm{~s}$ interval). The UV-vis spectra of the reaction were

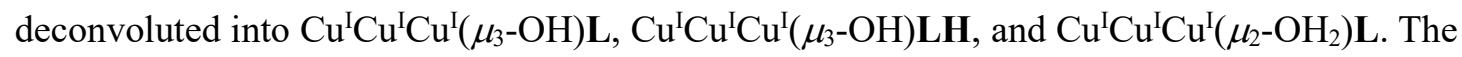
concentration of $\mathrm{Cu}^{\mathrm{I}} \mathrm{Cu}^{\mathrm{I}} \mathrm{Cu}^{\mathrm{I}}\left(\mu_{3}-\mathrm{OH}\right) \mathbf{L H}$ was plotted versus time (Figure S8A) to investigate the order of the rate law for Step 2. According to the plot of $\ln \left[\mathrm{Cu}^{\mathrm{I}} \mathrm{Cu}^{\mathrm{I}} \mathrm{Cu}^{\mathrm{I}}\left(\mu_{3}-\mathrm{OH}\right) \mathbf{L H}\right]$ versus time, Step 2 follows the first-order rate law very well (Figure S8B), and the rate of Step 2 is independent of the concentration of $\mathrm{Cu}^{\mathrm{I}} \mathrm{Cu}^{\mathrm{I}} \mathrm{Cu}^{\mathrm{I}}\left(\mu_{3}-\mathrm{OH}\right) \mathbf{L}$ (Figure S8C).
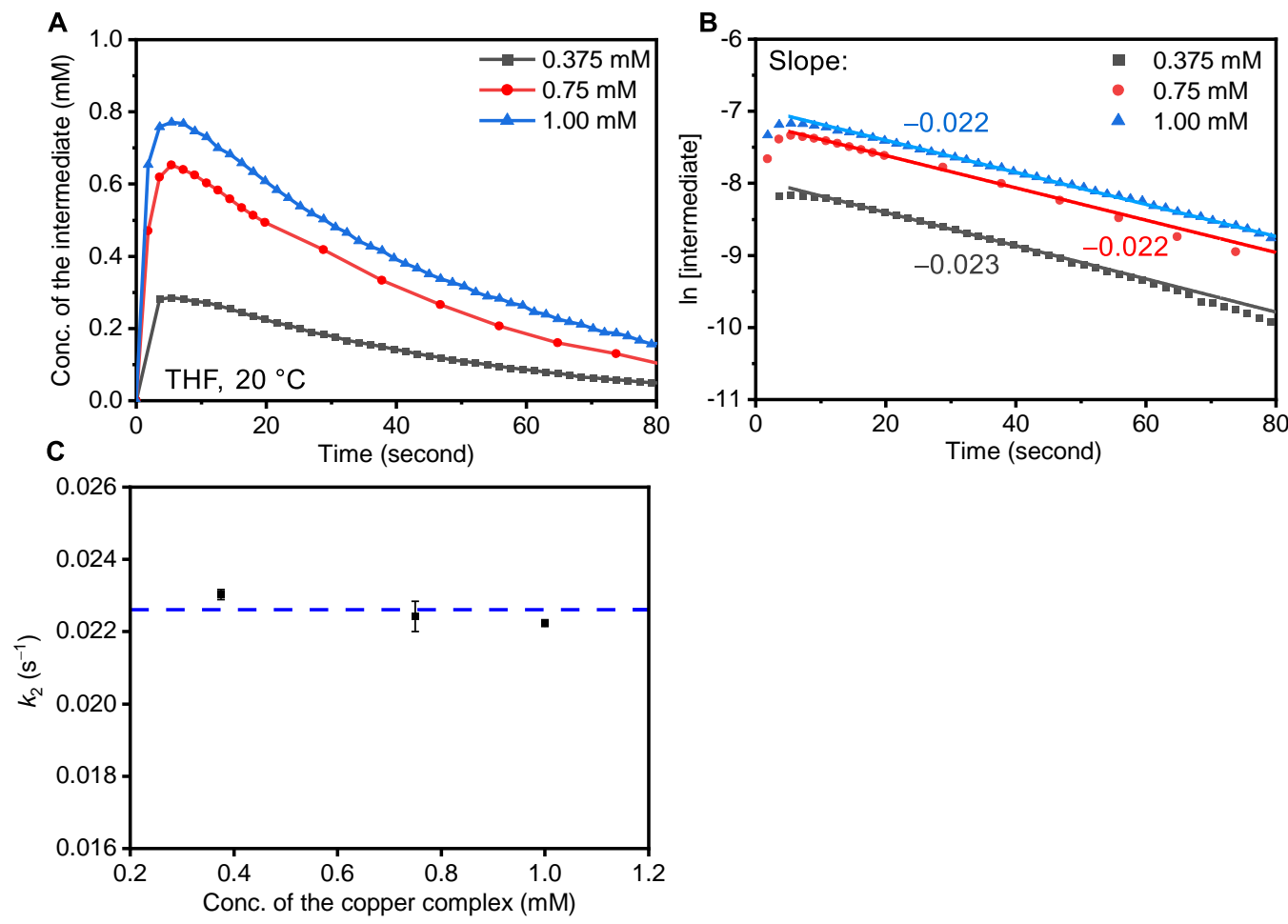

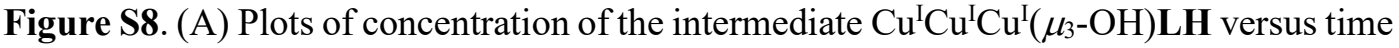
during the reation of $\mathrm{Cu}^{\mathrm{I}} \mathrm{Cu}^{\mathrm{I}} \mathrm{Cu}^{\mathrm{I}}\left(\mu_{3}-\mathrm{OH}\right) \mathbf{L}$ and $\left[\left(\mathrm{Et}_{2} \mathrm{O}\right)_{2} \mathrm{H}_{3} \mathrm{BAr}^{\mathrm{F}}\right.$. (B) First-order rate law plot for Step 2. The data spots from the first 6 seconds were not included due to the incompletion of step 1. (C) Summary of the first-order rate constant for Step 2 with different concentration of $\mathrm{Cu}^{\mathrm{I}} \mathrm{Cu}^{\mathrm{I}} \mathrm{Cu}^{\mathrm{I}}\left(\mu_{3}-\mathrm{OH}\right) \mathbf{L}$. 


\section{UV-vis titration of $\mathrm{Cu}^{\mathrm{I}} \mathrm{Cu}^{\mathrm{I}} \mathrm{Cu}^{\mathrm{I}}\left(\mu_{3}-\mathrm{OH}\right) \mathrm{L}$ with $\left[\left(\mathrm{Et}_{2} \mathrm{O}\right)_{2} \mathrm{H}\right] \mathrm{BAr}^{\mathrm{F}}{ }_{4}$}

$$
\begin{aligned}
& 1 \text { eq } \mathrm{Cu}^{\prime} \mathrm{Cu}^{\prime} \mathrm{Cu}^{\prime}\left(\mu_{3}-\mathrm{OH}\right) \mathbf{L}
\end{aligned}
$$

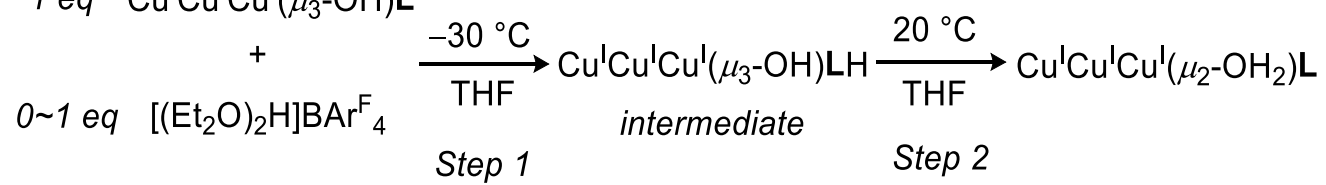

In glovebox, a THF solution $(2 \mathrm{~mL})$ of $\left[\mathrm{Cu}^{\mathrm{I}} \mathrm{Cu}^{\mathrm{I}} \mathrm{Cu}^{\mathrm{I}}\left(\mu_{3}-\mathrm{OH}\right) \mathbf{L}\right]\left(\mathrm{BAr}^{\mathrm{F}}\right)_{2}(4 \mathrm{mg}, 1.5 \mu \mathrm{mol})$ was transferred to a quartz cuvette equipped with a septum under $\mathrm{N}_{2}$. The cuvette was sealed and transferred to the UV-Vis spectrometer. Under nitrogen protection, a THF solution $(0.1 \mathrm{~mL})$ of $\left[\left(\mathrm{Et}_{2} \mathrm{O}\right)_{2} \mathrm{H}\right] \mathrm{BAr}_{4} \mathrm{~F}_{4}(0.3 \mathrm{mg}, 0.3 \mu \mathrm{mol})$ was injected into the cuvette by a $1-\mathrm{mL}$ syringe for five times with vigorous stirring under $-30{ }^{\circ} \mathrm{C}$. After each injection, the reaction was monitored with UV-vis (Figure S9A). Then the reaction was allowed to slowly warm to $20{ }^{\circ} \mathrm{C}$, and the formation of the peak at $320 \mathrm{~nm}$ was observed (Figure S9B). Due to the high intensity of the absorbance below $300 \mathrm{~nm}$, no isosbestic point was observed.
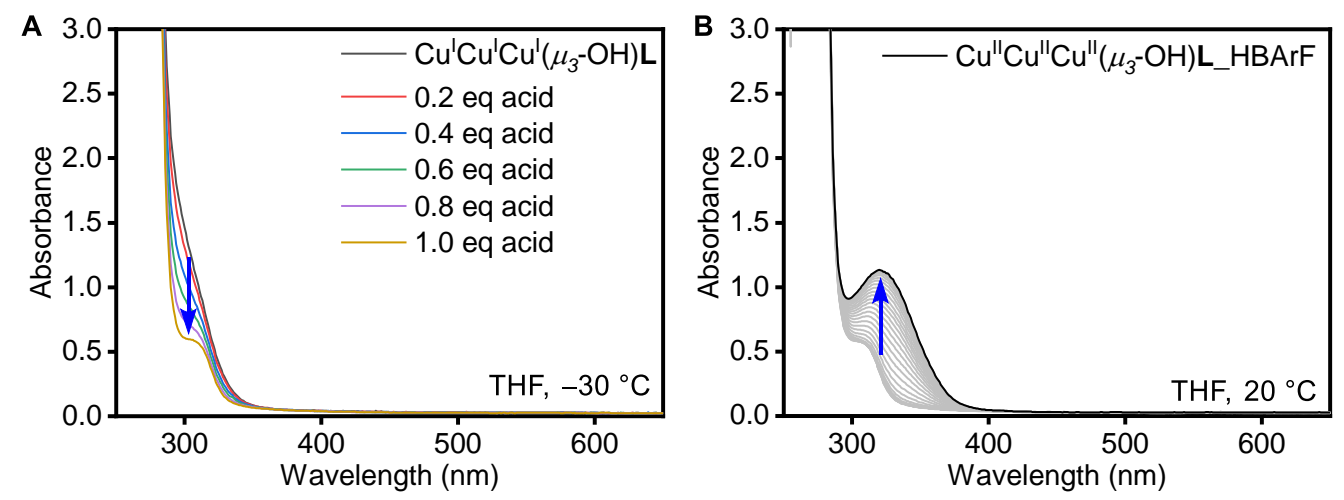

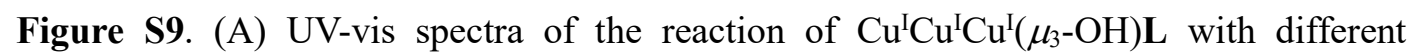
equivalents of $\left[\left(\mathrm{Et}_{2} \mathrm{O}\right)_{2} \mathrm{H}\right] \mathrm{Bar}^{\mathrm{F}}{ }_{4}$ at $-30{ }^{\circ} \mathrm{C}$ (Step 1). (B) $\mathrm{UV}$-vis spectra of the reaction from $\mathrm{Cu}^{\mathrm{I}} \mathrm{Cu}^{\mathrm{I}} \mathrm{Cu}^{\mathrm{I}}\left(\mu_{3}-\mathrm{OH}\right) \mathbf{L H}$ to $\mathrm{Cu}^{\mathrm{I}} \mathrm{Cu}^{\mathrm{I}} \mathrm{Cu}^{\mathrm{I}}\left(\mu_{2}-\mathrm{OH}_{2}\right) \mathbf{L}$ as the temperature increases to $20{ }^{\circ} \mathrm{C}$ (Step 2).

Kinetic study of the reaction between $\mathrm{Cu}^{\mathrm{II}} \mathrm{Cu}^{\mathrm{II}} \mathrm{Cu}^{\mathrm{II}}\left(\mu_{3}-\mathrm{O}\right) \mathrm{LH}$ and cobaltocene $\left(\mathrm{Cp}_{2} \mathrm{Co}\right)$

Step I Cull Cull Cu" $\left(\mu_{3}-\mathrm{O}\right) \mathrm{LH}+\mathrm{Cp}_{2} \mathrm{Co} \stackrel{\boldsymbol{k}_{1}}{\longrightarrow} \mathrm{Cu}^{\prime \prime} \mathrm{Cu}^{\prime \prime} \mathrm{Cu}^{\prime}\left(\mu_{3}-\mathrm{O}\right) \mathrm{LH}+\mathrm{Cp}_{2} \mathrm{Co}^{+}$ $1 \mathrm{eq} \quad 1 \mathrm{eq}$

Step II $\quad \mathrm{Cu}^{\prime \prime} \mathrm{Cu}^{\prime \prime} \mathrm{Cu}^{\prime}\left(\mu_{3}-\mathrm{O}\right) \mathrm{LH} \stackrel{\boldsymbol{k}_{\mathbf{2}}}{\longrightarrow} \mathrm{Cu}^{\prime \prime} \mathrm{Cu}^{\prime \prime} \mathrm{Cu}^{\prime}\left(\mu_{3}-\mathrm{OH}\right) \mathbf{L}$

Step III $\left[\begin{array}{c}\mathrm{Cu}^{\prime \prime} \mathrm{Cu}^{\prime \prime} \mathrm{Cu}^{\prime}\left(\mu_{3}-\mathrm{O}\right) \mathrm{LH} \\ + \\ \mathrm{Cu}^{\prime \prime} \mathrm{Cu}^{\prime \prime} \mathrm{Cu}\left(\mu_{3}-\mathrm{OH}\right) \mathrm{L}\end{array}\right] \stackrel{\boldsymbol{k}_{\mathbf{3}}}{\underset{\boldsymbol{k}_{-3}}{\rightleftharpoons}}\left[\begin{array}{c}\mathrm{Cu}^{\prime \prime} \mathrm{Cu}^{\prime \prime} \mathrm{Cu}^{\prime \prime}\left(\mu_{3}-\mathrm{O}\right) \mathrm{LH} \\ + \\ \mathrm{Cu}^{\prime \prime} \mathrm{Cu} u^{\prime} \mathrm{Cu}\left(\mu_{3}-\mathrm{OH}\right) \mathrm{L}\end{array}\right]$

In glovebox, an acetone solution $(3 \mathrm{~mL})$ of $\left[\mathrm{Cu}^{\mathrm{II}} \mathrm{Cu}^{\mathrm{II}} \mathrm{Cu}^{\mathrm{II}}\left(\mu_{3}-\mathrm{O}\right) \mathbf{L H}\right]\left(\mathrm{PF}_{6}\right)_{5}(2 \mathrm{mg}, 1.2 \mu \mathrm{mol})$ was transferred to a quartz cuvette equipped with a septum under $\mathrm{N}_{2}$. The cuvette was sealed and 
transferred to the UV-Vis spectrometer. Under nitrogen protection, an acetone solution $(0.1 \mathrm{~mL})$ of $\mathrm{Cp}_{2} \mathrm{Co}(0.23 \mathrm{mg}, 1.2 \mu \mathrm{mol})$ was injected into the cuvette using a 1-mL syringe with vigorous stirring. The progress of the reaction was monitored with $\mathrm{UV}$-vis at $-50{ }^{\circ} \mathrm{C}(6 \mathrm{~s}$ interval $),-60{ }^{\circ} \mathrm{C}$ (6 s interval), $-70{ }^{\circ} \mathrm{C}\left(15 \mathrm{~s}\right.$ interval), and $-80{ }^{\circ} \mathrm{C}(30 \mathrm{~s}$ interval), respectively (Figure $\mathrm{S} 10)$. The UV-vis spectrum of the reaction was deconvoluted into $\mathrm{Cu}^{\mathrm{II}} \mathrm{Cu}^{\mathrm{II}} \mathrm{Cu}^{\mathrm{II}}\left(\mu_{3}-\mathrm{O}\right) \mathbf{L H}, \mathrm{Cu}^{\mathrm{II}} \mathrm{Cu}^{\mathrm{II}} \mathrm{Cu}^{\mathrm{I}}\left(\mu_{3}-\right.$ O) $\mathbf{L H}$, and $\mathrm{Cu}^{\mathrm{II}} \mathrm{Cu}^{\mathrm{I}} \mathrm{Cu}^{\mathrm{I}}\left(\mu_{3}-\mathrm{OH}\right) \mathbf{L}$. The concentrations of each species were plotted versus time in Figure S11. In-situ generated $\mathrm{Cu}^{\mathrm{II}} \mathrm{Cu}^{\mathrm{II}} \mathrm{Cu}^{\mathrm{I}}\left(\mu_{3}-\mathrm{OH}\right) \mathbf{L}$ in Step II is proposed to be quickly consumed in Step III due to the fast disproportionation. The rate constant for each step was simulated by plotting the concentration versus time with the software KinTek Explorer.
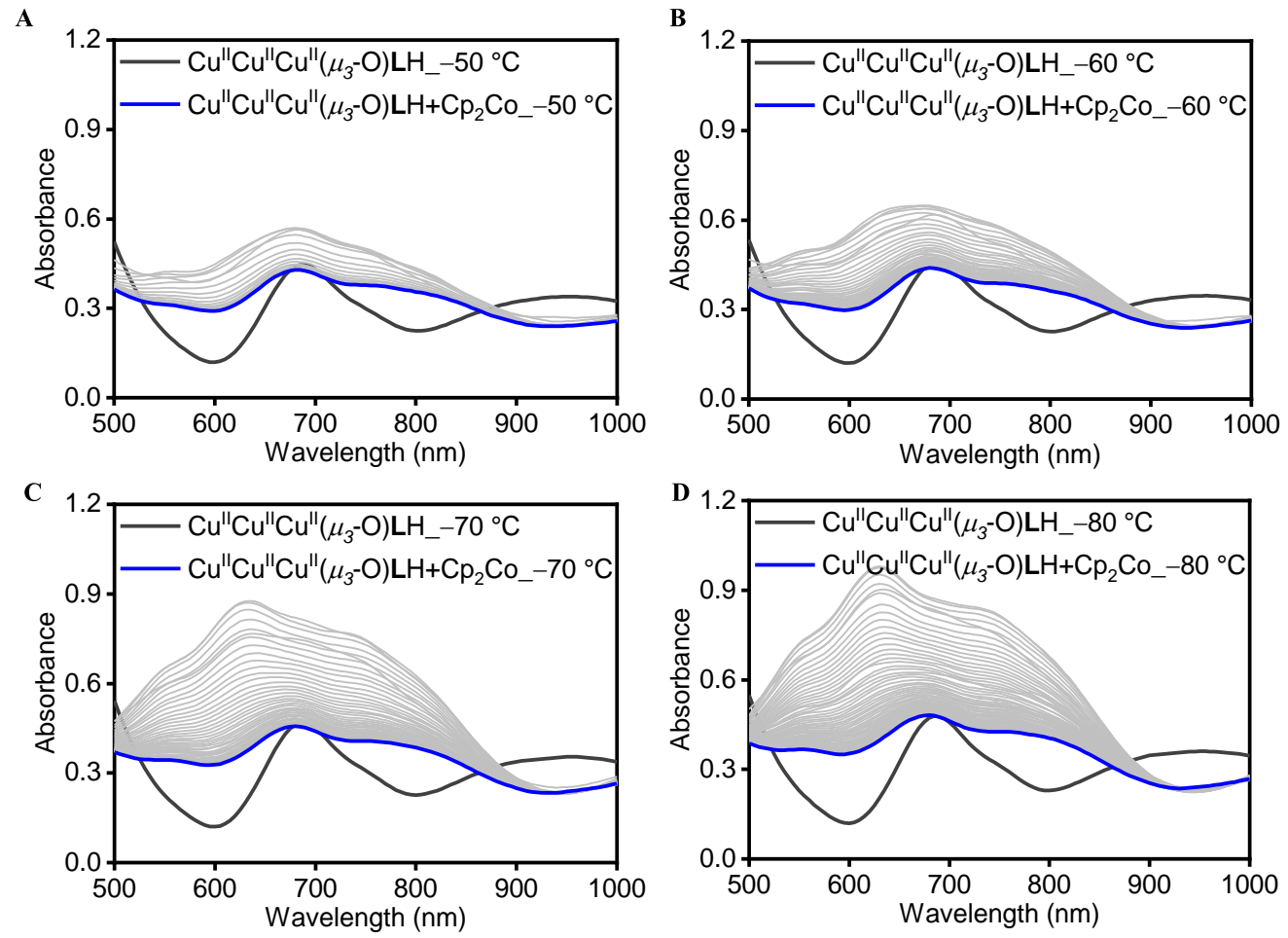

Figure S10. UV-vis spectrum of the reaction between $\mathrm{Cu}^{\mathrm{II}} \mathrm{Cu}^{\mathrm{II}} \mathrm{Cu}^{\mathrm{II}}\left(\mu_{3}-\mathrm{O}\right) \mathbf{L H}$ and $\mathrm{Cp}_{2} \mathrm{Co}$ in acetone at $-50{ }^{\circ} \mathrm{C}(\mathrm{A}),-60{ }^{\circ} \mathrm{C}(\mathrm{B}),-70{ }^{\circ} \mathrm{C}(\mathrm{C})$, and $-80{ }^{\circ} \mathrm{C}(\mathrm{D})$. 

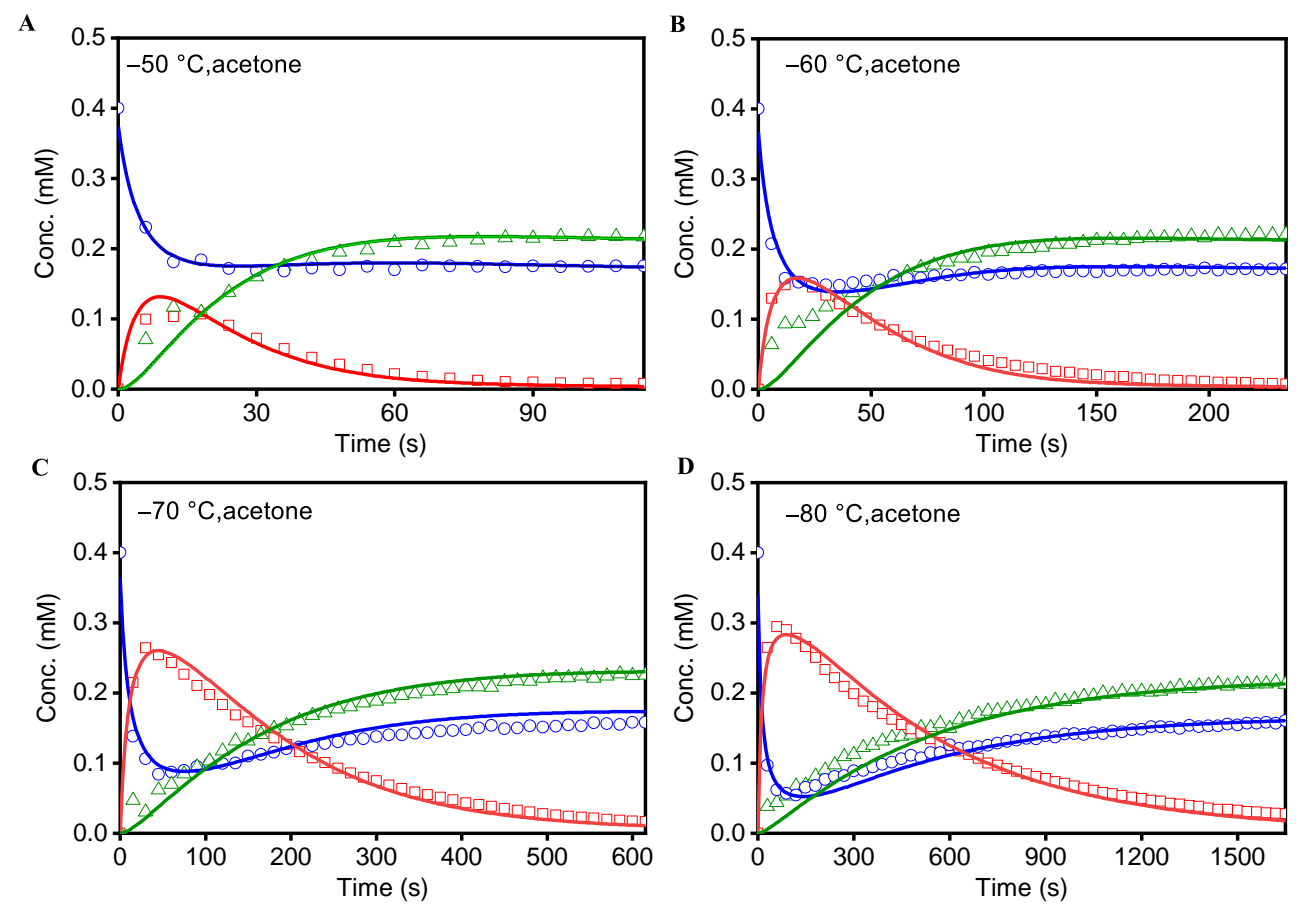

Figure S11. Kinetic simulation at (A) $-50{ }^{\circ} \mathrm{C}$, (B) $-60{ }^{\circ} \mathrm{C}$, (C) $-70{ }^{\circ} \mathrm{C}$, and (D) $-80{ }^{\circ} \mathrm{C}$. $\mathrm{Cu}^{\mathrm{II}} \mathrm{Cu}^{\mathrm{II}} \mathrm{Cu}^{\mathrm{II}}\left(\mu_{3}-\mathrm{O}\right) \mathbf{L H}$ (blue circle: experiment data; blue line: simulated data). $\mathrm{Cu}^{\mathrm{II}} \mathrm{Cu}^{\mathrm{II}} \mathrm{Cu}^{\mathrm{I}}\left(\mu_{3}-\mathrm{O}\right) \mathbf{L H}$ (red square: experiment data; red line: simulated data). $\mathrm{Cu}^{\mathrm{II}} \mathrm{Cu}^{\mathrm{I}} \mathrm{Cu}^{\mathrm{I}}\left(\mu_{3}-\mathrm{OH}\right) \mathbf{L}$ (green triangle: experiment data; green line: simulated data). The reverse reaction for step I and II was neglect and treated as irreversible reaction. $k_{3}$ and $k_{-3}$ was estimated from experimental CV and CV simulation.

\begin{tabular}{|c|c|c|c|c|}
\hline $\begin{array}{c}\text { Temperature } \\
\left({ }^{\circ} \mathrm{C}\right)\end{array}$ & -50 & -60 & -70 & -80 \\
\hline \multirow{3}{*}{$\begin{array}{c}k_{1} \\
\left(\mathrm{M}^{-1} \mathrm{~s}^{-1}\right)\end{array}$} & $3.4 \times 10^{2}$ & $2.3 \times 10^{2}$ & $1.9 \times 10^{2}$ & $1.6 \times 10^{2}$ \\
\hline & $4.3 \times 10^{2}$ & $2.7 \times 10^{2}$ & $2.1 \times 10^{2}$ & $2.0 \times 10^{2}$ \\
\hline & $4.6 \times 10^{2}$ & $3.1 \times 10^{2}$ & $2.4 \times 10^{2}$ & $2.7 \times 10^{2}$ \\
\hline \multirow{3}{*}{$\begin{array}{c}k_{2} \\
\left(\mathrm{~s}^{-1}\right)\end{array}$} & $3.2 \times 10^{-2}$ & $1.4 \times 10^{-2}$ & $3.3 \times 10^{-3}$ & $1.0 \times 10^{-3}$ \\
\hline & $34 \times 10^{-2}$ & $1.6 \times 10^{-2}$ & $3.3 \times 10^{-3}$ & $1.0 \times 10^{-3}$ \\
\hline & $3.7 \times 10^{-2}$ & $1.8 \times 10^{-2}$ & $3.5 \times 10^{-3}$ & $1.1 \times 10^{-3}$ \\
\hline $\begin{array}{cc}k_{3} & \begin{array}{c}\text { lower } \\
\left(\mathrm{M}^{-1} \mathrm{~s}^{-1}\right)\end{array} \\
& \begin{array}{c}\text { Best fit } \\
\text { upper }\end{array}\end{array}$ & $6.9 \times 10^{4} \mathrm{a}$ & $3.5 \times 10^{4} \mathrm{a}$ & $1.7 \times 10^{4 \mathrm{a}}$ & $7.6 \times 10^{3} \mathrm{a}$ \\
\hline \multirow{3}{*}{$\begin{array}{cc}k_{-3} & \begin{array}{c}\text { lower } \\
\left(\mathrm{M}^{-1} \mathrm{~s}^{-1}\right) \\
\text { Best fit } \\
\text { upper }\end{array}\end{array}$} & - & - & - & - \\
\hline & $2.2 \times 10^{2} \mathrm{a}$ & $8.6 \times 10^{1 \mathrm{a}}$ & $3.1 \times 10^{1 \mathrm{a}}$ & $1.0 \times 10^{1 \mathrm{a}}$ \\
\hline & - & - & - & - \\
\hline
\end{tabular}

Table S2: Summary of rate constant from kinetic simulation for the reaction reaction between $\mathrm{Cu}^{\mathrm{II}} \mathrm{Cu}^{\mathrm{II}} \mathrm{Cu}^{\mathrm{II}}\left(\mu_{3}-\mathrm{O}\right) \mathbf{L H}$ and $\mathrm{Cp}_{2} \mathrm{Co}$. The upper and lower limits for rate constant were derived from the threshold of $\mathrm{Chi}^{2}{ }_{\text {min }} / \mathrm{Chi}^{2}=0.9 .{ }^{\text {a: }}$ locked values (see section 8 blow). Fixed values for $k_{3}$ at different temperature are the lower bound of $k_{3}$ obtained from section 8 and increasing $k_{3}$ will not change the simulated curve. Fixed values for $k_{-3}$ at different temperature are calculated with known $K_{\mathrm{eq}}=k_{3} / k_{-3}$, which is obtained from CV experiments. 


\section{UV-vis titration of $\mathrm{Cu}^{\mathrm{II}} \mathrm{Cu}^{\mathrm{II}} \mathrm{Cu}^{\mathrm{II}}\left(\mu_{3}-\mathrm{O}\right) \mathrm{LH}$ with cobaltocene $\left(\mathrm{Cp}_{2} \mathrm{Co}\right)$}

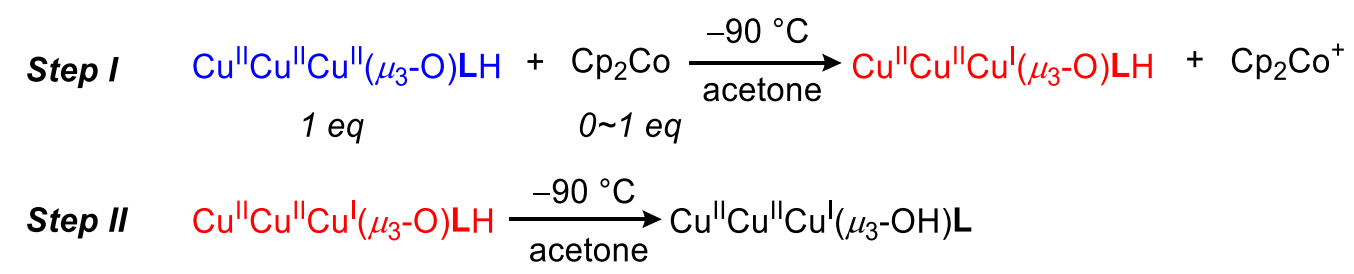

Step III $\left[\begin{array}{c}\mathrm{Cu}^{\prime \prime} \mathrm{Cu}^{\prime \prime} \mathrm{Cu}^{\prime}\left(\mu_{3}-\mathrm{O}\right) \mathrm{LH} \\ + \\ \mathrm{Cu}^{\prime \prime} \mathrm{Cu} \mathrm{H}^{\prime \prime} \mathrm{Cu}\left(\mu_{3}-\mathrm{OH}\right) \mathrm{L}\end{array}\right] \longrightarrow\left[\begin{array}{c}\mathrm{Cu}^{\prime \prime} \mathrm{Cu}^{\prime \prime} \mathrm{Cu}^{\prime \prime}\left(\mu_{3}-\mathrm{O}\right) \mathrm{LH} \\ + \\ \mathrm{Cu}^{\prime \prime} \mathrm{Cu}^{\prime} \mathrm{Cu}\left(\mu_{3}-\mathrm{OH}\right) \mathrm{L}\end{array}\right]$

In glovebox, an acetone solution $(3 \mathrm{~mL})$ of $\left[\mathrm{Cu}^{\mathrm{II}} \mathrm{Cu}^{\mathrm{II}} \mathrm{Cu}^{\mathrm{II}}\left(\mu_{3}-\mathrm{O}\right) \mathbf{L H}\right]\left(\mathrm{PF}_{6}\right)_{5}(2 \mathrm{mg}, 1.2 \mu \mathrm{mol})$ was transferred to a quartz cuvette equipped with a septum under $\mathrm{N}_{2}$. The cuvette was sealed and transferred to the UV-Vis spectrometer. Under nitrogen protection, an acetone solution $(0.1 \mathrm{~mL})$ of $\mathrm{Cp}_{2} \mathrm{Co}(0.046 \mathrm{mg}, 0.24 \mu \mathrm{mol})$ was injected into the cuvette using a 1-mL syringe five times with vigorous stirring under $-90^{\circ} \mathrm{C}$. After each injection, the reaction was monitored with UVvis, and two isosbestic points $(510 \mathrm{~nm}, 890 \mathrm{~nm})$ were observed (Figure S12A). Then, the UVvis sample was allowed to warm up to $-50{ }^{\circ} \mathrm{C}$, during which an intramolecular proton transfer (Step II) and a disproportionation (Step III) occurred. According to the decay of the broad peak at $630 \mathrm{~nm}$ during the temperature increase, two different isosbestic points $(460 \mathrm{~nm}, 920 \mathrm{~nm})$ were observed (Figure S12B).
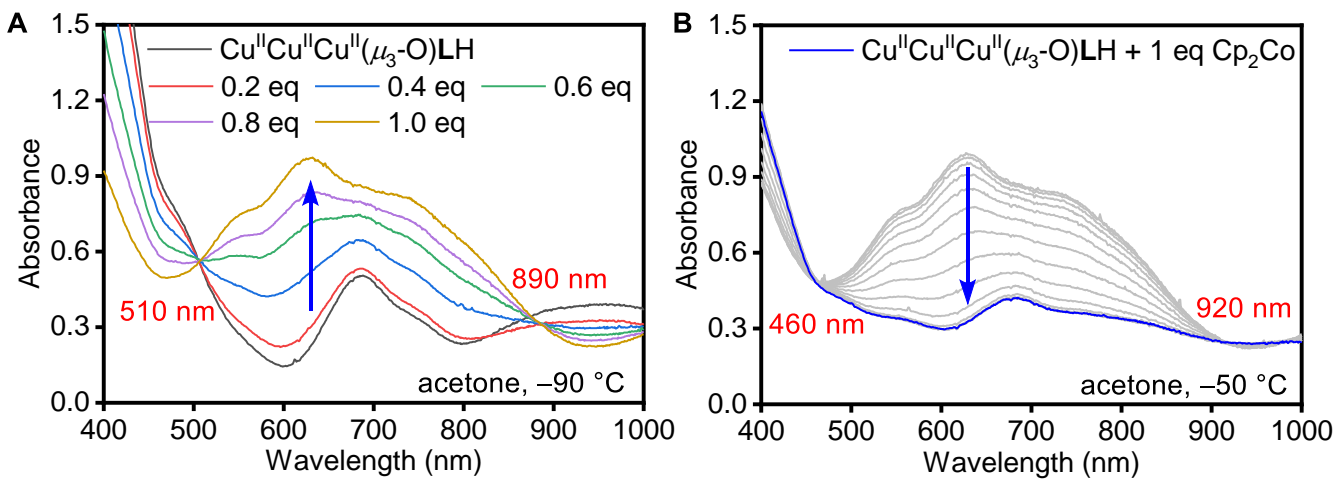

Figure S12. (A) In-situ UV-vis spectra of the reaction of $\mathrm{Cu}^{\mathrm{II}} \mathrm{Cu}^{\mathrm{II}} \mathrm{Cu}^{\mathrm{II}}\left(\mu_{3}-\mathrm{O}\right) \mathbf{L} \mathbf{H}$ with different equivalents of $\mathrm{Cp}_{2} \mathrm{Co}$ at $-90{ }^{\circ} \mathrm{C}$ (Step I). (B) In-situ UV-vis spectra of the intramolecular proton transfer from $\mathrm{Cu}^{\mathrm{II}} \mathrm{Cu}^{\mathrm{II}} \mathrm{Cu}^{\mathrm{I}}\left(\mu_{3}-\mathrm{O}\right) \mathbf{L} \mathbf{H}$ to $\mathrm{Cu}^{\mathrm{II}} \mathrm{Cu}^{\mathrm{II}} \mathrm{Cu}^{\mathrm{I}}\left(\mu_{3}-\mathrm{OH}\right) \mathbf{L}$ at $-50{ }^{\circ} \mathrm{C}$ followed by disproportionation (Step II, Step III). 
Kinetic study of the reaction of $\mathrm{Cu}^{\mathrm{II}} \mathrm{Cu}^{\mathrm{I}} \mathrm{Cu}^{\mathrm{I}}\left(\mu_{3}-\mathrm{OH}\right) \mathrm{L},\left[\left(\mathrm{Et}_{2} \mathrm{O}\right)_{2} \mathrm{H}\right] \mathrm{BAr} \mathrm{r}_{4}^{\mathrm{F}}$, and decamethylferrocene $\left(\mathrm{Fc}^{*}\right)$.

$$
\mathrm{Cu}_{1 \mathrm{eq}} \mathrm{Cu}^{\prime} \mathrm{Cu}^{\prime}\left(\mu_{3}-\mathrm{OH}\right) \mathrm{L}+\underset{3 \mathrm{eq}}{\left[\left(\mathrm{Et}_{2} \mathrm{O}\right)_{2} \mathrm{H}_{\mathrm{B}} \mathrm{BAr}_{4}\right.} \underset{{ }_{2}}{\stackrel{k_{1}}{\rightleftharpoons}} \mathrm{Cu}^{\prime \prime} \mathrm{Cu}^{\prime} \mathrm{Cu}^{\prime}\left(\mu_{3}-\mathrm{OH}\right) \mathrm{LH} \underset{k_{2}}{\stackrel{2}{\rightleftharpoons}} \mathrm{Cu}^{\prime} \mathrm{Cu}^{\prime} \mathrm{Cu}^{\prime}\left(\mu_{2}-\mathrm{OH}_{2}\right) \mathrm{L}
$$

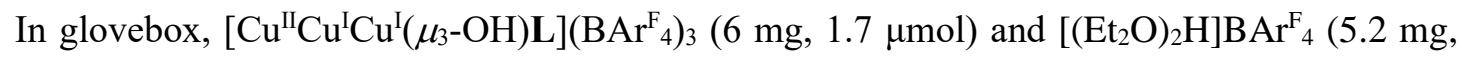
$5.1 \mu \mathrm{mol})$ were mixed in THF $(2 \mathrm{~mL})$. The obtained solution was transferred to a septum quartz cuvette under $\mathrm{N}_{2}$. The cuvette was sealed and transferred to the UV-Vis spectrometer. Under nitrogen protection, a THF $(0.1 \mathrm{~mL})$ solution of decamethylferrocene $(1.1 \mathrm{mg}, 3.4 \mu \mathrm{mol})$ was injected into the cuvette by a $1-\mathrm{mL}$ syringe with vigorous stirring. The absorption at $560 \mathrm{~nm}$, which indicates the concentration of $\left[\mathrm{Cu}^{\mathrm{II}} \mathrm{Cu}^{\mathrm{I}} \mathrm{Cu}^{\mathrm{I}}\left(\mu_{3}-\mathrm{OH}\right) \mathbf{L}\right]\left(\mathrm{BAr}_{4}\right)_{3}$ was monitored (Figure S13, $0.025 \mathrm{~s}$ time intervals). The kinetic data were simulated with the software KinTek Explorer, and the results are summarized in Table S3.
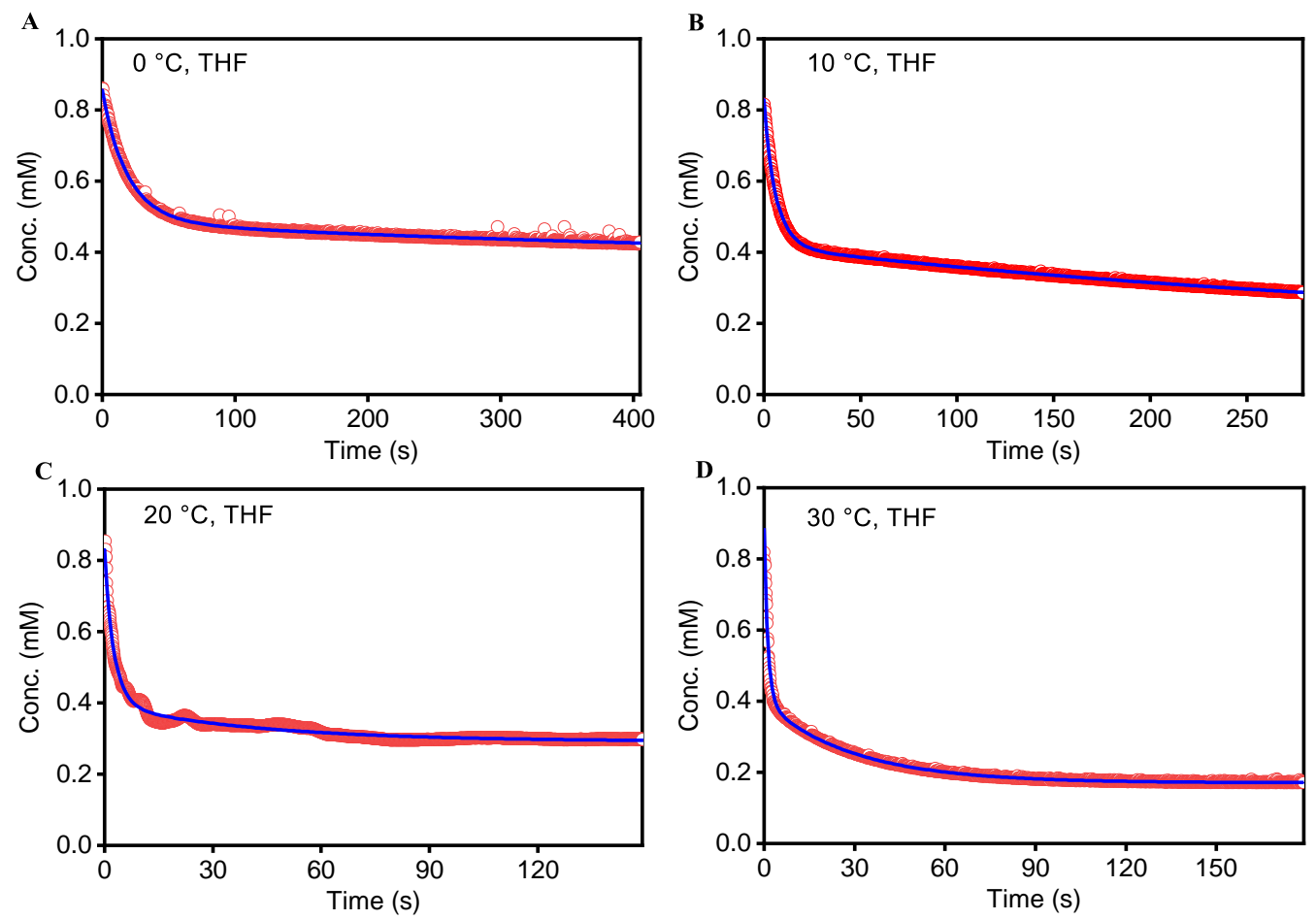

Figure S13. Kinetic simulation at (A) $0{ }^{\circ} \mathrm{C}$, (B) $10{ }^{\circ} \mathrm{C}$, (C) $20{ }^{\circ} \mathrm{C}$, and (D) $30{ }^{\circ} \mathrm{C}$. $\mathrm{Cu}^{\mathrm{II}} \mathrm{Cu}^{\mathrm{I}} \mathrm{Cu}^{\mathrm{I}}\left(\mu_{3}-\mathrm{OH}\right) \mathbf{L H}$ (red circle: experiment data; blue line: simulated data). 


\begin{tabular}{|c|c|c|c|c|}
\hline $\begin{array}{c}\text { Temperature } \\
\left({ }^{\circ} \mathrm{C}\right)\end{array}$ & $\mathbf{0}$ & 10 & 20 & 30 \\
\hline \multirow{2}{*}{$\begin{array}{c}\boldsymbol{k}_{\mathbf{1}} \\
\left(\mathrm{M}^{-1} \mathrm{~s}^{-1}\right)\end{array}$} & $3.5 \times 10^{-1}$ & $1.6 \times 10^{0}$ & $8.4 \times 10^{0}$ & $2.0 \times 10^{1}$ \\
\hline & $8.4 \times 10^{-1}$ & $1.8 \times 10^{0}$ & $1.1 \times 10^{1}$ & $2.2 \times 10^{1}$ \\
\hline$\left(\mathrm{I} \mathrm{S}^{\mathrm{S}}\right.$ upper & $1.4 \times 10^{0}$ & $1.9 \times 10^{0}$ & $1.3 \times 10^{1}$ & $2.4 \times 10^{1}$ \\
\hline \multirow{2}{*}{$\begin{array}{l}\boldsymbol{k}_{-1} \\
\left(\mathrm{~s}^{-1}\right)\end{array}$} & $2.6 \times 10^{-2}$ & $7.4 \times 10^{-2}$ & $1.4 \times 10^{-1}$ & $2.8 \times 10^{-1}$ \\
\hline & $2.7 \times 10^{-2}$ & $7.5 \times 10^{-2}$ & $1.6 \times 10^{-1}$ & $3.1 \times 10^{-1}$ \\
\hline (S) upper & $2.7 \times 10^{-2}$ & $7.6 \times 10^{-2}$ & $1.8 \times 10^{-1}$ & $3.4 \times 10^{-1}$ \\
\hline \multirow{3}{*}{$\begin{array}{cc}\boldsymbol{k}_{\mathbf{2}} & \begin{array}{c}\text { lower } \\
\text { Best fit } \\
\left(\mathrm{M}^{-1} \mathrm{~s}^{-1}\right)\end{array} \\
& \begin{array}{c}\text { upper } \\
\end{array}\end{array}$} & $1.4 \times 10^{1}$ & $5.2 \times 10^{1}$ & $1.2 \times 10^{2}$ & $2.7 \times 10^{2}$ \\
\hline & $1.4 \times 10^{1}$ & $5.3 \times 10^{1}$ & $1.3 \times 10^{2}$ & $3.0 \times 10^{2}$ \\
\hline & $1.5 \times 10^{1}$ & $5.4 \times 10^{1}$ & $1.5 \times 10^{2}$ & $3.3 \times 10^{2}$ \\
\hline
\end{tabular}

Table S3: Summary of rate constant from kinetic simulation for the reaction between $\mathrm{Cu}^{\mathrm{II}} \mathrm{Cu}^{\mathrm{I}} \mathrm{Cu}^{\mathrm{I}}\left(\mu_{3}-\mathrm{OH}\right) \mathbf{L},\left[\left(\mathrm{Et}_{2} \mathrm{O}\right)_{2} \mathrm{H}\right] \mathrm{BAr}_{4}^{\mathrm{F}}$, and $\mathrm{Fc}^{*}$. The upper and lower limits for rate constant were derived from the threshold of $\mathrm{Chi}^{2}{ }_{\mathrm{min}} / \mathrm{Chi}^{2}=0.9$.

Determining the rate law of the reaction between $\mathrm{Cu}^{\mathrm{II}} \mathrm{Cu}^{\mathrm{I}} \mathrm{Cu}^{\mathrm{I}}\left(\mu_{3}-\mathrm{OH}\right) \mathrm{L},\left[\left(\mathrm{Et}_{2} \mathrm{O}\right)_{2} \mathrm{H}\right] \mathrm{BAr}^{\mathrm{F}}$, and decamethylferrocene ( $\left.\mathrm{Fc}^{*}\right)$.

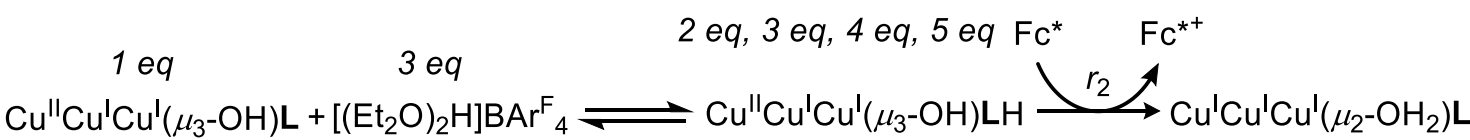

In glovebox, $\left[\mathrm{Cu}^{\mathrm{II}} \mathrm{Cu}^{\mathrm{I}} \mathrm{Cu}^{\mathrm{I}}\left(\mu_{3}-\mathrm{OH}\right) \mathbf{L}\right]\left(\mathrm{BAr}_{4}\right)_{3}(6 \mathrm{mg}, 1.7 \mu \mathrm{mol})$ and $\left[\left(\mathrm{Et}_{2} \mathrm{O}\right)_{2} \mathrm{H}\right] \mathrm{BAr}_{4}{ }_{4}(5.2 \mathrm{mg}$, $5.1 \mu \mathrm{mol})$ were mixed in THF $(2 \mathrm{~mL})$. The obtained solution was transferred to a septum quartz cuvette under $\mathrm{N}_{2}$. The cuvette was sealed and transferred to the UV-Vis spectrometer. Under nitrogen protection, a THF $(0.1 \mathrm{~mL})$ solution of decamethylferrocene $(1.1 \mathrm{mg}$ for $2 \mathrm{eq}, 1.7 \mathrm{mg}$ for $3 \mathrm{eq}, 2.2 \mathrm{mg}$ for $4 \mathrm{eq}, 2.8 \mathrm{mg}$ for $5 \mathrm{eq}$ with respect to the tricopper complex) was injected into the cuvette by a $1-\mathrm{mL}$ syringe with vigorous stirring. The absorption at $560 \mathrm{~nm}$, which indicates the concentration of $\left[\mathrm{Cu}^{\mathrm{II}} \mathrm{Cu}^{\mathrm{I}} \mathrm{Cu}^{\mathrm{I}}\left(\mu_{3}-\mathrm{OH}\right) \mathbf{L}\right]\left(\mathrm{BAr}_{4}^{\mathrm{F}}\right)_{3}$ was monitored (Figure S14A, $0.025 \mathrm{~s}$ time intervals). The initial rate of the reaction shows a first-order correlation with the equivalents of $\mathrm{Fc}^{*}$ (Figure $\mathrm{S} 14 \mathrm{~B}$ ).
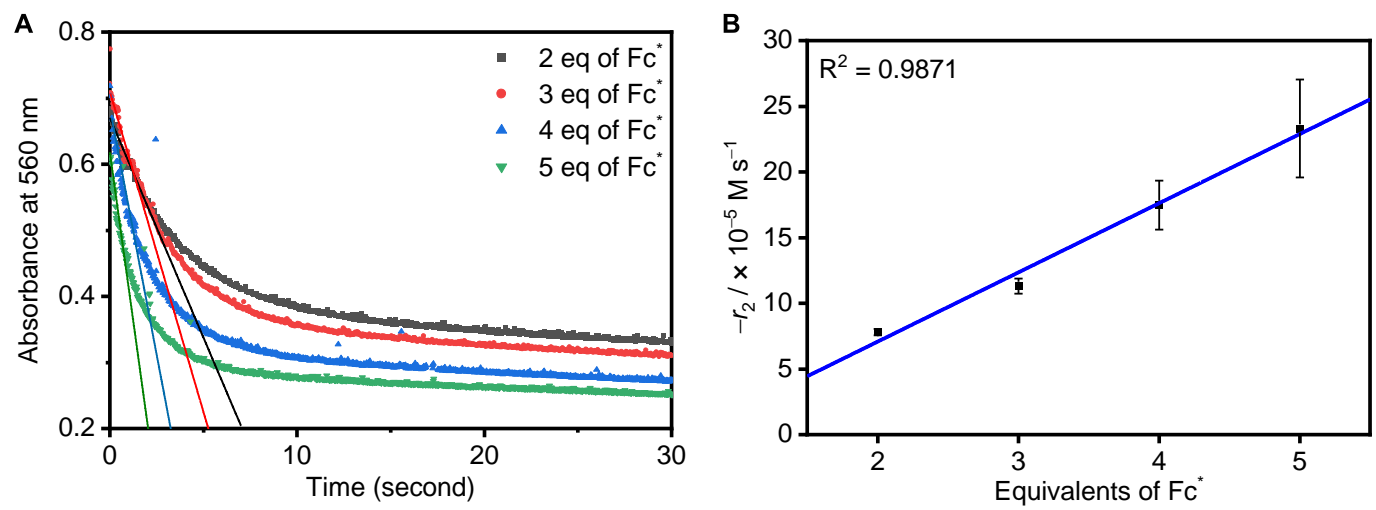

Figure S14: (A) Plots of absorbance at $560 \mathrm{~nm}\left(\mathrm{Cu}^{\mathrm{II}} \mathrm{Cu}^{\mathrm{I}} \mathrm{Cu}^{\mathrm{I}}\left(\mu_{3}-\mathrm{OH}\right) \mathbf{L}\right)$ versus time during the reaction. (B) Plot of the initial rate of the reaction versus the equivalents of $\mathrm{Fc}^{*}$. 


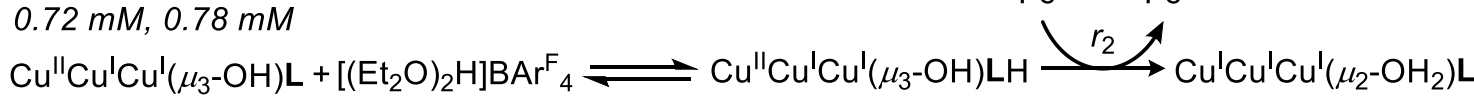

In glovebox, different amount of $\left[\mathrm{Cu}^{\mathrm{II}} \mathrm{Cu}^{\mathrm{I}} \mathrm{Cu}^{\mathrm{I}}\left(\mu_{3}-\mathrm{OH}\right) \mathbf{L}\right]\left(\mathrm{BAr}^{\mathrm{F}}\right)_{3}(3.4 \mathrm{mg}$ for $0.48 \mathrm{mM}, 4.1 \mathrm{mg}$ for $0.58 \mathrm{mM}, 5.1 \mathrm{mg}$ for $0.72 \mathrm{mM}, 5.6 \mathrm{mg}$ for $0.79 \mathrm{mM})$ was mixed with $\left[\left(\mathrm{Et}_{2} \mathrm{O}\right)_{2} \mathrm{H}\right] \mathrm{BAr}^{\mathrm{F}}{ }_{4}(3.4$ $\mathrm{mg}, 3.4 \mu \mathrm{mol})$ in THF $(2 \mathrm{~mL})$, respectively. The obtained solution was transferred to a septum quartz cuvette under $\mathrm{N}_{2}$. The cuvette was sealed and transferred to the UV-Vis spectrometer. Under nitrogen protection, a THF $(0.1 \mathrm{~mL})$ solution of decamethylferrocene $(1.1 \mathrm{mg}, 3.4 \mu \mathrm{mol})$ was injected into the cuvette by a $1-\mathrm{mL}$ syringe with vigorous stirring. The absorption at 560 $\mathrm{nm}$, which indicates the concentration of $\left[\mathrm{Cu}^{\mathrm{II}} \mathrm{Cu}^{\mathrm{I}} \mathrm{Cu}^{\mathrm{I}}\left(\mu_{3}-\mathrm{OH}\right) \mathbf{L}\right]\left(\mathrm{BAr}^{\mathrm{F}}{ }_{4}\right)_{3}$ was monitored (Figure $\mathrm{S} 15 \mathrm{~A}, 0.025 \mathrm{~s}$ time intervals). The initial rate of the reaction shows a first-order correlation with the concentration of $\mathrm{Cu}^{\mathrm{II}} \mathrm{Cu}^{\mathrm{I}} \mathrm{Cu}^{\mathrm{I}}\left(\mu_{3}-\mathrm{OH}\right) \mathbf{L}$ (Figure S15B).
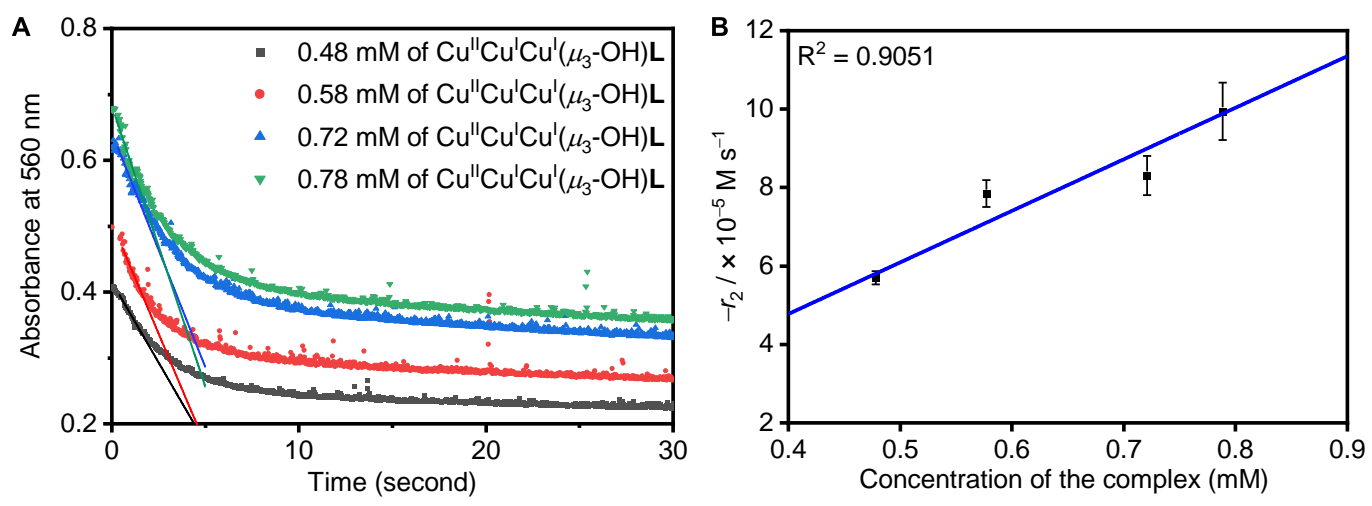

Figure S15: (A) Plots of absorbance at $560 \mathrm{~nm}$ versus time during the reaction. (B) Plot of the initial rate of the reaction versus the concentration of $\mathrm{Cu}^{\mathrm{II}} \mathrm{Cu}^{\mathrm{I}} \mathrm{Cu}^{\mathrm{I}}\left(\mu_{3}-\mathrm{OH}\right) \mathbf{L}$.

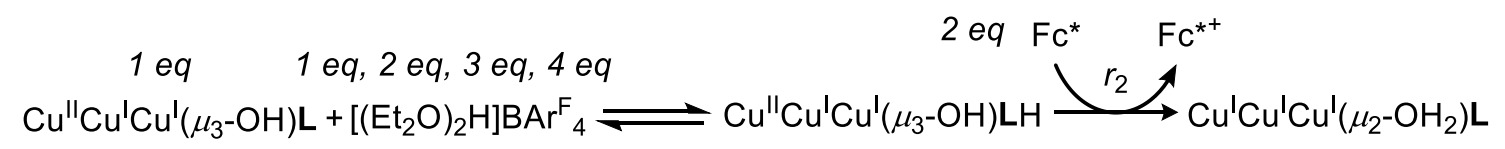

In glovebox, different equivalents of $\left[\left(\mathrm{Et}_{2} \mathrm{O}\right)_{2} \mathrm{H}\right] \mathrm{BAr}_{4}{ }_{4}(1.7 \mathrm{mg}$ for $1 \mathrm{eq}, 3.4 \mathrm{mg}$ for $2 \mathrm{eq}, 5.2 \mathrm{mg}$ for $3 \mathrm{eq}, 6.8 \mathrm{mg}$ for 4 eq with respect to the tricopper complex) were mixed with $\left[\mathrm{Cu}^{\mathrm{II}} \mathrm{Cu}^{\mathrm{I}} \mathrm{Cu}^{\mathrm{I}}\left(\mu_{3}-\right.\right.$ $\mathrm{OH}) \mathbf{L}]\left(\mathrm{BAr}_{4}\right)_{3}(6 \mathrm{mg}, 1.7 \mu \mathrm{mol})$ in THF $(2 \mathrm{~mL})$, respectively. The obtained solution was transferred to a septum quartz cuvette under $\mathrm{N}_{2}$. The cuvette was sealed and transferred to the
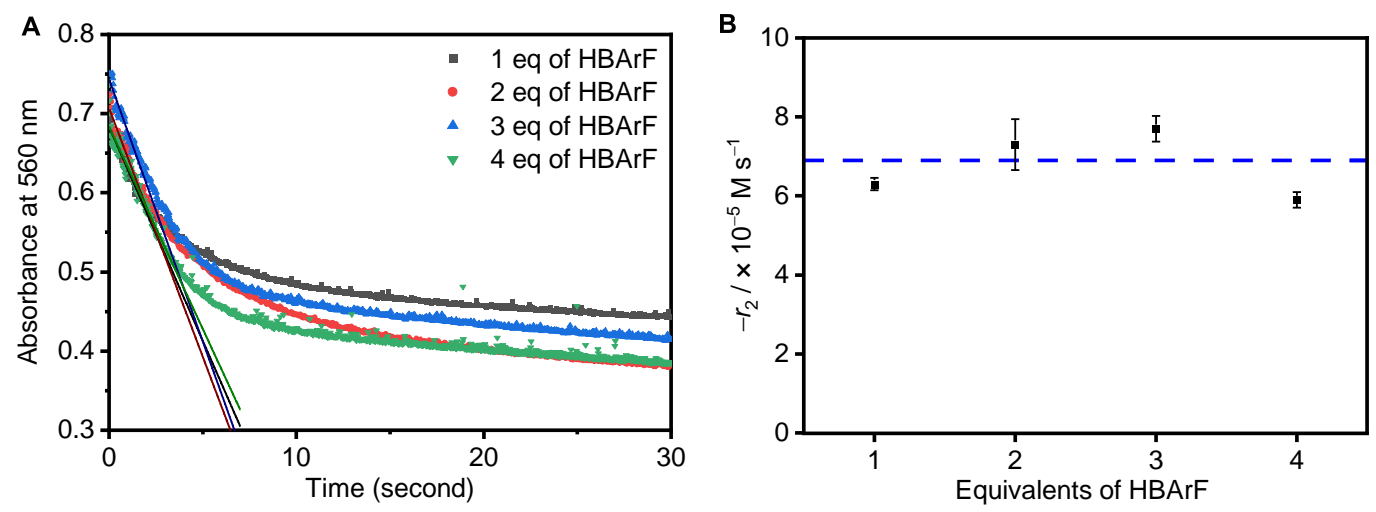

Figure S16: (A) Plot of absorbance at $560 \mathrm{~nm}$ versus time during the reaction. (B) Plot of the initial rate of the reaction versus the equivalents of $\left[\left(\mathrm{Et}_{2} \mathrm{O}\right)_{2} \mathrm{H}\right] \mathrm{BAr}{ }_{4}$. 
UV-Vis spectrometer. Under nitrogen protection, a THF $(0.1 \mathrm{~mL})$ solution of decamethylferrocene $(1.1 \mathrm{mg}, 3.4 \mu \mathrm{mol})$ was injected into the cuvette by a $1-\mathrm{mL}$ syringe with vigorous stirring. The absorption at $560 \mathrm{~nm}$, which indicates the concentration of $\left[\mathrm{Cu}^{\mathrm{II}} \mathrm{Cu}^{\mathrm{I}} \mathrm{Cu}^{\mathrm{I}}\left(\mu_{3}-\mathrm{OH}\right) \mathbf{L}\right]\left(\mathrm{BAr}_{4}^{\mathrm{F}}\right)_{3}$ was monitored (Figure S16A, $0.025 \mathrm{~s}$ time intervals). The initial rate of the reaction shows a zeroth-order correlation with the equivalent of $\left[\left(\mathrm{Et}_{2} \mathrm{O}\right)_{2} \mathrm{H}\right] \mathrm{BArr}_{4}$ (Figure S16B).

Oxidation of $\mathrm{Cu}^{\mathrm{I}} \mathrm{Cu}^{\mathrm{I}} \mathrm{Cu}^{\mathrm{I}}\left(\mu_{2}-\mathrm{OH}_{2}\right) \mathrm{L}$ with ferrocenium tetrakis[3,5bis(trifluoromethyl)phenyl]borate $\left(\mathrm{FcBAr}^{\mathrm{F}}{ }_{4}\right)$.

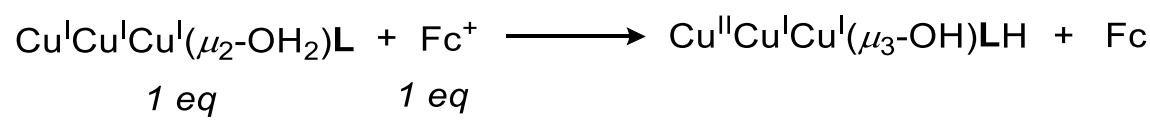

In glovebox, $\left[\mathrm{Cu}^{\mathrm{I}} \mathrm{Cu}^{\mathrm{I}} \mathrm{Cu}^{\mathrm{I}}\left(\mu_{3}-\mathrm{OH}\right) \mathbf{L}\right]\left(\mathrm{BAr}_{4}\right)_{2}(4 \mathrm{mg}, 1.5 \mu \mathrm{mol})$ and $\left[\left(\mathrm{Et}_{2} \mathrm{O}\right)_{2} \mathrm{H}_{3}\right] \mathrm{BAr}_{4}{ }_{4}(2.1 \mathrm{mg}, 2.1$ $\mu \mathrm{mol})$ were mixed in THF $(2 \mathrm{~mL})$. The resulting solution was transferred to a quartz cuvette equipped with a septum under $\mathrm{N}_{2}$. The cuvette was sealed and transferred to the UV-Vis spectrometer. Under nitrogen protection, a THF $(0.6 \mathrm{~mL})$ solution of decamethylferrocene $(0.32$ $\mathrm{mg}, 0.3 \mu \mathrm{mol}$ ) was titrated into the cuvette in six $0.1 \mathrm{~mL}$ intervals (Figure S17A). UV-vis spectra were collected after each addition of decamethylferrocene. The absorbance at $790 \mathrm{~nm}$, which indicates the concentration of $\left[\mathrm{Cu}^{\mathrm{II}} \mathrm{Cu}^{\mathrm{I}} \mathrm{Cu}^{\mathrm{I}}\left(\mu_{3}-\mathrm{OH}\right) \mathbf{L}\right]\left(\mathrm{BAr}^{\mathrm{F}}\right)_{2}$, was plotted against the stoichiometry of decamethylferrocene in Figure S17B. The data show the oxidation of $\left[\mathrm{Cu}^{\mathrm{I}} \mathrm{Cu}^{\mathrm{I}} \mathrm{Cu}^{\mathrm{I}}\left(\mu_{3}-\mathrm{OH}\right) \mathbf{L}\right]\left(\mathrm{BAr}_{4}^{\mathrm{F}}\right)_{2}$ to $\left[\mathrm{Cu}^{\mathrm{II}} \mathrm{Cu}^{\mathrm{I}} \mathrm{Cu}^{\mathrm{I}}\left(\mu_{3}-\mathrm{OH}\right) \mathbf{L}\right]\left(\mathrm{BAr}_{4}^{\mathrm{F}}\right)_{2}$ requires one equivalent of oxidant, suggesting one-electron oxidation of $\mathrm{Cu}^{\mathrm{I}} \mathrm{Cu}^{\mathrm{I}} \mathrm{Cu}^{\mathrm{I}}\left(\mu_{2}-\mathrm{OH}_{2}\right) \mathrm{L}$ with $\mathrm{Fc} \mathrm{BAr}_{4}{ }_{4}$.
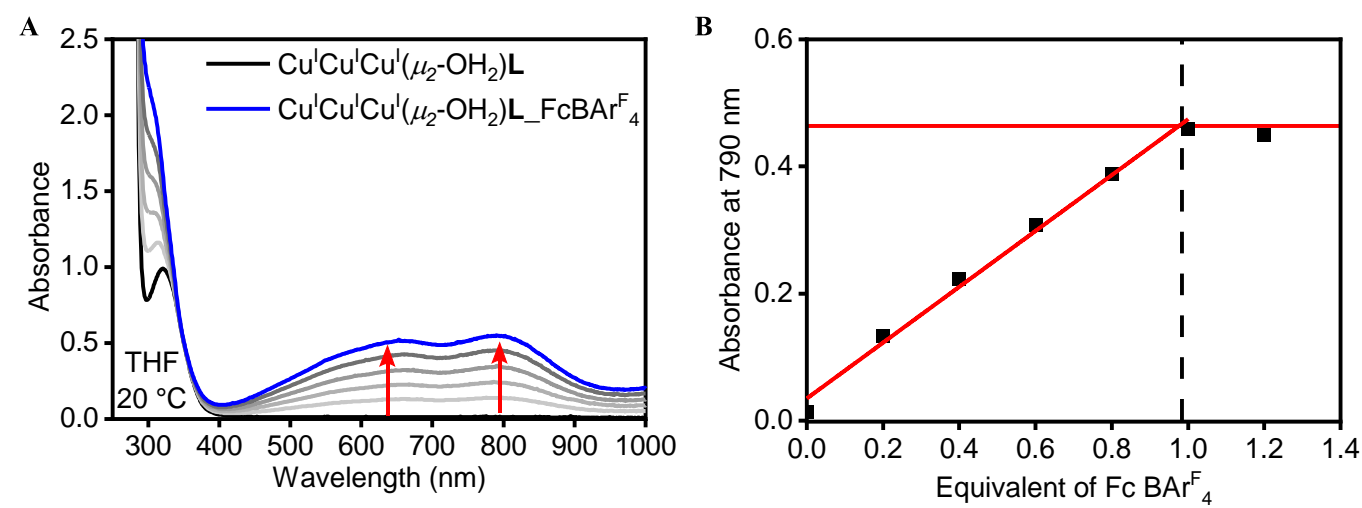

Figure S17. (A) UV-vis spectrum of the reaction between $\mathrm{Cu}^{\mathrm{I}} \mathrm{Cu}^{\mathrm{I}} \mathrm{Cu}^{\mathrm{I}}\left(\mu_{2}-\mathrm{OH}_{2}\right) \mathbf{L}$ and $\mathrm{Fc}$ $\mathrm{BAr}_{4}{ }_{4}$ in THF at $20^{\circ} \mathrm{C}$. (B) Absorbance at $790 \mathrm{~nm}$ as a function of different equivalents of $\mathrm{Fc} \mathrm{BAr}_{4}$.

\section{Details of ${ }^{1} \mathbf{H}$ NMR spectroscopy study}

${ }^{1} \mathrm{H}$ NMR study of the reaction of $\mathrm{Cu}^{\mathrm{II}} \mathrm{Cu}^{\mathrm{I}} \mathrm{Cu}^{\mathrm{I}}\left(\mu_{3}-\mathrm{OH}\right) \mathrm{L},\left[\left(\mathrm{Et}_{2} \mathrm{O}\right)_{2} \mathrm{H}\right] \mathrm{BAr}^{\mathrm{F}}{ }_{4}$, and 
decamethylferrocene $\left(\mathrm{Fc}^{*}\right)$.

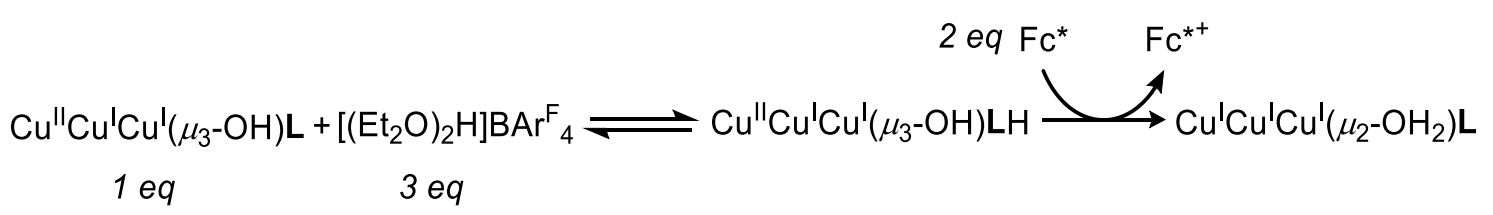

$\left[\mathrm{Cu}^{\mathrm{II}} \mathrm{Cu}^{\mathrm{I}} \mathrm{Cu}^{\mathrm{I}}\left(\mu_{3}-\mathrm{OH}\right) \mathbf{L}\right]\left(\mathrm{BAr}_{4}{ }_{4}\right)_{3}(7.3 \mathrm{mg}, 2.07 \mu \mathrm{mol})$ was dissolved in THF- $d_{8}(0.4 \mathrm{~mL})$ under $\mathrm{N}_{2}$ and transferred to a J-Young NMR tube in the glovebox. J-Young NMR tube was sealed and sent to ${ }^{1} \mathrm{H}$ NMR characterization (Figure $\mathrm{S} 18$, trace 1). The paramagnetic proton signals marked with blue dots are assigned to $\mathrm{C}-\mathrm{H}$ protons on the TREN 4 ligand. The J-Young NMR tube was transferred back in the glovebox, and the sample solution was pipette out to a vial that contains $\left[\left(\mathrm{Et}_{2} \mathrm{O}\right)_{2} \mathrm{H}\right] \mathrm{BAr}_{4}{ }_{4}(6.3 \mathrm{mg}, 6.22 \mu \mathrm{mol})$. The mixture was transferred back to the J-Young NMR tube, and the vial was washed with THF- $d_{8}$ solution $(0.1 \mathrm{~mL})$. After mixing the wash solution with the solution in the J-Young NMR tube, the tube was sealed and sent to ${ }^{1} \mathrm{H}$ NMR characterization (Figure S18, trace 2). The paramagnetic proton signals from the $\mathbf{T R E N} \mathbf{N}_{4}$ ligand did not change (Figure S18, trace 2, blue dots). The proton signal from leftover $\left[\left(\mathrm{Et}_{2} \mathrm{O}\right)_{2} \mathrm{H}\right] \mathrm{BAr}_{4}$ was marked with a green dot, which has the same chemical shift with proton signal from pure $\left[\left(\mathrm{Et}_{2} \mathrm{O}\right)_{2} \mathrm{H}\right] \mathrm{BAr}_{4}{ }_{4}$ (Figure S18, trace 4). The new proton signal marked with an orange dot was then attributed to the proton that protonates the $\mathbf{T R E N} 4$ ligand.

To the current NMR sample in the J-Young NMR tube, THF- $\mathrm{d}_{8}$ solution $(0.2 \mathrm{~mL})$ solution of $\mathrm{Fc}^{*}(1.4 \mathrm{mg}, 0.00414 \mathrm{mmol})$ was added. The mixture quickly turned to green from blue. ${ }^{1} \mathrm{H}$ NMR spectrum of the green mixture (Figure S18, trace 3) showed the typical proton signal (red

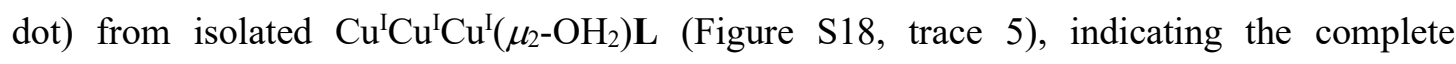

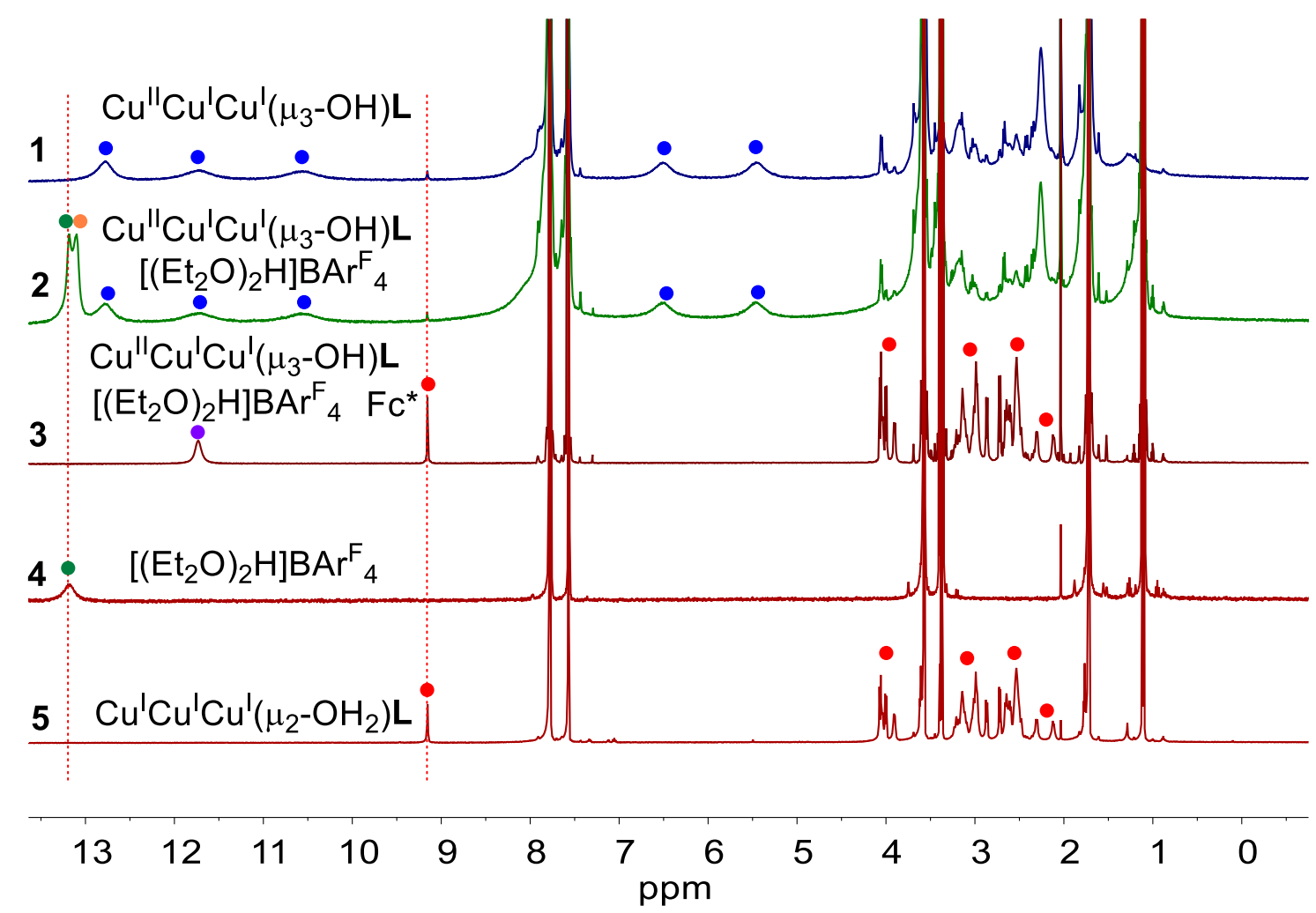

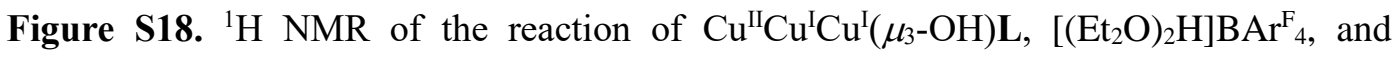
decamethylferrocene $\left(\mathrm{Fc}^{*}\right)$. 
conversion to $\mathrm{Cu}^{\mathrm{I}} \mathrm{Cu}^{\mathrm{I}} \mathrm{Cu}^{\mathrm{I}}\left(\mu_{3}-\mathrm{OH}\right) \mathbf{L}$. The broad signal labeled with a purple dot perhaps originates from protonation of $\mathrm{Fc}^{*}$ by leftover $\left[\left(\mathrm{Et}_{2} \mathrm{O}\right)_{2} \mathrm{H}\right] \mathrm{BAr}_{4}{ }_{4}$.

\section{${ }^{1} \mathrm{H}$ NMR study of the reaction of $\mathrm{Cu}^{\mathrm{II}} \mathrm{Cu}^{\mathrm{I}} \mathrm{Cu}^{\mathrm{I}}\left(\mu_{3}-\mathrm{OH}\right) \mathrm{L}$ and $\left[\left(\mathrm{Et}_{2} \mathrm{O}\right)_{2} \mathrm{H}\right] \mathrm{BAr}^{\mathrm{F}}{ }_{4}$}

$$
\begin{aligned}
& \mathrm{Cu}^{\prime \prime} \mathrm{Cu}^{\prime} \mathrm{Cu}^{\prime}\left(\mu_{3}-\mathrm{OH}\right) \mathrm{L}+\left[\left(\mathrm{Et}_{2} \mathrm{O}\right)_{2} \mathrm{H}\right] \mathrm{BAr}_{4} \rightleftharpoons \mathrm{Cu}_{4} \mathrm{Cu}^{\prime} \mathrm{Cu}^{\prime}\left(\mu_{3}-\mathrm{OH}\right) \mathrm{LH} \\
& 1 \text { eq } \quad 0 \sim 3 \text { eq }
\end{aligned}
$$

$\left[\mathrm{Cu}^{\mathrm{II}} \mathrm{Cu}^{\mathrm{I}} \mathrm{Cu}^{\mathrm{I}}\left(\mu_{3}-\mathrm{OH}\right) \mathbf{L}\right]\left(\mathrm{BAr}_{4}^{\mathrm{F}}\right)_{3}(7.3 \mathrm{mg}, 2.07 \mu \mathrm{mol})$ was dissolved in THF- $d_{8}(0.5 \mathrm{~mL})$ under $\mathrm{N}_{2}$ and transferred to a J-Young NMR tube in the glovebox. J-Young NMR tube was sealed and sent to ${ }^{1} \mathrm{H}$ NMR characterization (Figure S19, trace 1). The paramagnetic proton signals marked with blue dots are assigned to $\mathrm{C}-\mathrm{H}$ protons from the $\mathbf{T R E N}_{4}$ ligand. The J-Young NMR tube was transferred back in the glovebox, and the sample solution was pipette out to a vial that contains $\left[\left(\mathrm{Et}_{2} \mathrm{O}\right)_{2} \mathrm{H}\right] \mathrm{BAr}_{4}{ }_{4}(0.7 \mathrm{mg}, 0.69 \mu \mathrm{mol}, 0.33 \mathrm{eq})$. The mixture was transferred back to the J-Young NMR tube and sent to ${ }^{1} \mathrm{H}$ NMR characterization (Figure S19, trace 2). The same process was repeated four times to give traces 3, 4, 5, and 6 in Figure S19. No new peak that can be assigned to the proton that protonates the tricopper complex is observed with 0.33 and 0.66 equivalent of $\left(\mathrm{Et}_{2} \mathrm{O}\right)_{2} \mathrm{H} \mathrm{BAr}_{4}{ }_{4}$ (Figure $\mathrm{S} 19$, trace 2, trace 3). After adding 1, 1.33, and 1.66 equivalent of $\left(\mathrm{Et}_{2} \mathrm{O}\right)_{2} \mathrm{H} \mathrm{BAr} \mathrm{F}_{4}$, a new broad peak was observed and shifted with a different equivalent of $\left(\mathrm{Et}_{2} \mathrm{O}\right)_{2} \mathrm{H} \mathrm{BAr}{ }_{4}$. Due to the overlap between the new broad peak and the paramagnetic $\mathrm{C}-\mathrm{H}$ signals from the ligand and the paramagnetic nature of the complex, we

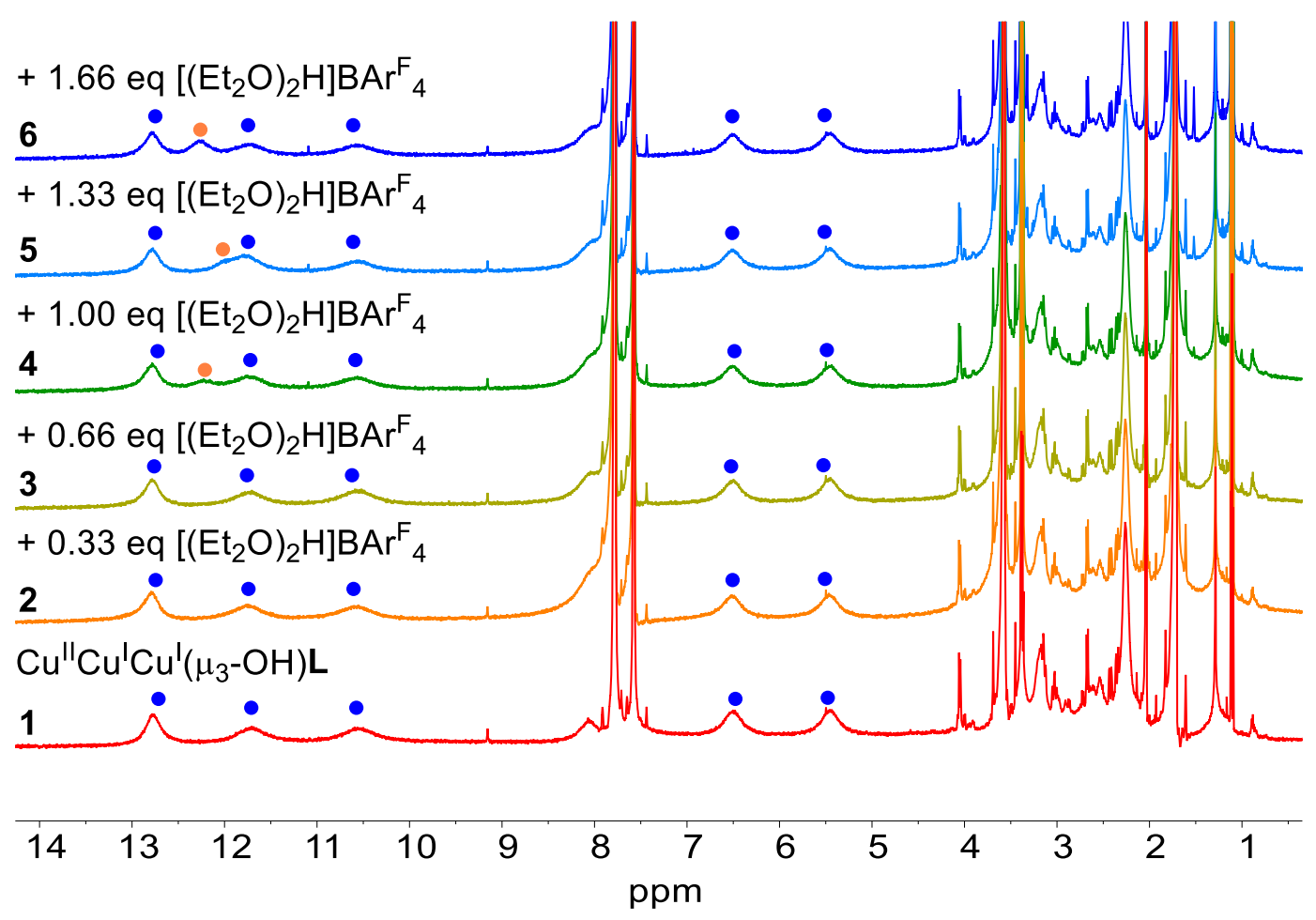

Figure S19. ${ }^{1} \mathrm{H}$ NMR of the reaction of $\mathrm{Cu}^{\mathrm{II}} \mathrm{Cu}^{\mathrm{I}} \mathrm{Cu}^{\mathrm{I}}\left(\mu_{3}-\mathrm{OH}\right) \mathbf{L}$ and different equivalents of $\left[\left(\mathrm{Et}_{2} \mathrm{O}\right)_{2} \mathrm{H}\right] \mathrm{BAr}_{4}{ }_{4}$ 
concluded that it would be difficult to obtain a reliable integration of the new broad peak and calculate the $K_{\text {eq }}$ of the reaction between $\mathrm{Cu}^{\mathrm{II}} \mathrm{Cu}^{\mathrm{I}} \mathrm{Cu}^{\mathrm{I}}\left(\mu_{3}-\mathrm{OH}\right) \mathbf{L}$ and $\left[\left(\mathrm{Et}_{2} \mathrm{O}\right)_{2} \mathrm{H}\right] \mathrm{BAr}_{4}$.

${ }^{1} \mathrm{H}$ NMR study of the reaction of $\mathrm{Cu}^{\mathrm{I}} \mathrm{Cu}^{\mathrm{I}} \mathrm{Cu}^{\mathrm{I}}\left(\mu_{3}-\mathrm{OH}\right) \mathrm{L}$ and $\left[\left(\mathrm{Et}_{2} \mathrm{O}\right)_{2} \mathrm{H}\right] \mathrm{BAr}^{\mathrm{F}}{ }_{4}$ at $-50{ }^{\circ} \mathrm{C}$.

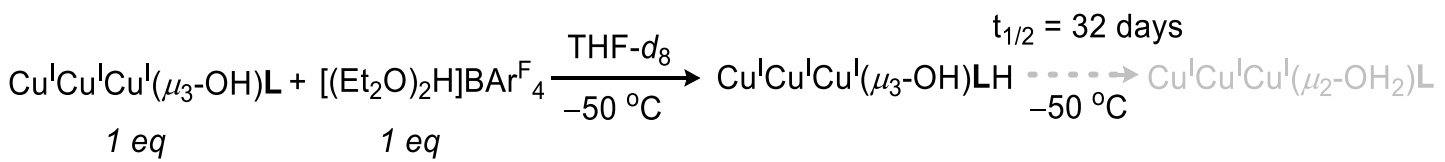

$\left[\mathrm{Cu}^{\mathrm{I}} \mathrm{Cu}^{\mathrm{I}} \mathrm{Cu}^{\mathrm{I}}\left(\mu_{3}-\mathrm{OH}\right) \mathbf{L}\right]\left(\mathrm{BAr}^{\mathrm{F}}\right)_{2}(5 \mathrm{mg}, 1.88 \mu \mathrm{mol})$ was dissolved in THF- $d_{8}(0.4 \mathrm{~mL})$ under $\mathrm{N}_{2}$ and transferred to a J-Young NMR tube in the glovebox. A THF- $d_{8}$ solution of $\left[\left(\mathrm{Et}_{2} \mathrm{O}\right)_{2} \mathrm{H}\right] \mathrm{BAr}_{4}$ $\left(1.9 \mathrm{mg}, 1.88 \mu \mathrm{mol}\right.$ ) was prepared in $0.1 \mathrm{~mL}$ THF- $d_{8}$ and stored in a 1-mL syringe under $\mathrm{N}_{2}$. The J-Young NMR tube and the syringe were transferred outside the glovebox and the syringe was quickly sealed by sticking the needle into a rubber septum. The upper part of the J-Young NMR tube was set in a sufficient $\mathrm{N}_{2}$ flow, while the bottom of the J-Young NMR tube was immersed in a dry-ice-acetone cooling bath $\left(-78^{\circ} \mathrm{C}\right)$. The THF- $d_{8}$ solution of $\left[\left(\mathrm{Et}_{2} \mathrm{O}\right)_{2} \mathrm{H}\right] \mathrm{B} \mathrm{Ar}_{4} \mathrm{~F}_{4}$ was injected into the J-Young NMR tube, followed by a gentle shake to ensure sufficient mixing. Two control NMR experiments were also prepared in parallel. First, a THF- $d_{8}$ solution $(0.4 \mathrm{~mL})$ of $\left[\mathrm{Cu}^{\mathrm{I}} \mathrm{Cu}^{\mathrm{I}} \mathrm{Cu}^{\mathrm{I}}\left(\mu_{3}-\mathrm{OH}\right) \mathbf{L}\right]\left(\mathrm{BAr}_{4}^{\mathrm{F}}\right)_{2}(5 \mathrm{mg}, 1.88 \mu \mathrm{mol})$ was mixed with a THF- $d_{8}$ solution $(0.1$ $\mathrm{mL})$ of $\left[\left(\mathrm{Et}_{2} \mathrm{O}\right)_{2} \mathrm{H}\right] \mathrm{BAr}_{4} \mathrm{~F}_{4}(1.9 \mathrm{mg}, 1.88 \mu \mathrm{mol})$ in a J-Young NMR tube at room temperature under $\mathrm{N}_{2}$. Additionally, a THF- $d_{8}$ solution $(0.5 \mathrm{~mL})$ of $\left[\mathrm{Cu}^{\mathrm{I}} \mathrm{Cu}^{\mathrm{I}} \mathrm{Cu}^{\mathrm{I}}\left(\mu_{3}-\mathrm{OH}\right) \mathbf{L}\right]\left(\mathrm{BAr}_{4}^{\mathrm{F}}\right)_{2}(5 \mathrm{mg}$, $1.88 \mu \mathrm{mol}$ ) was prepared in a J-Young NMR tube. All three samples were freshly made and stored in dry-ice-acetone cooling bath prior to the low temperature ${ }^{1} \mathrm{H}$ NMR study. All three ${ }^{1} \mathrm{H}$ NMR spectra were taken ${ }^{1} \mathrm{H}$ NMR at $-50{ }^{\circ} \mathrm{C}$.

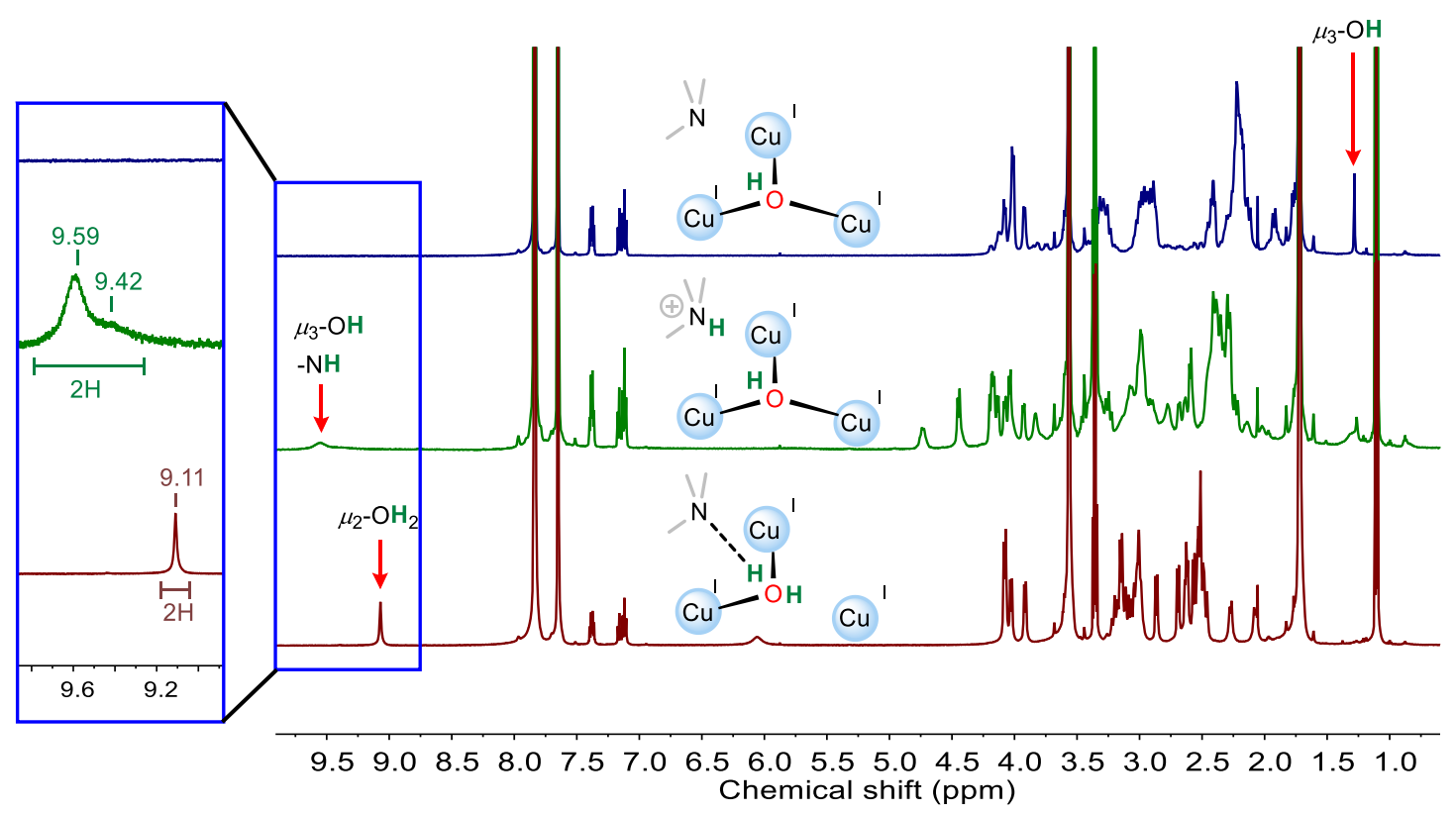

Figure S20. ${ }^{1} \mathrm{H}$ NMR of the reaction of $\mathrm{Cu}^{\mathrm{I}} \mathrm{Cu}^{\mathrm{I}} \mathrm{Cu}^{\mathrm{I}}\left(\mu_{3}-\mathrm{OH}\right) \mathbf{L}$ and $\left[\left(\mathrm{Et}_{2} \mathrm{O}\right)_{2} \mathrm{H}\right] \mathrm{B} \mathrm{Ar}^{\mathrm{F}}{ }_{4}$ in THF$d_{8}$. The spectra of $\mathrm{Cu}^{\mathrm{I}} \mathrm{Cu}^{\mathrm{I}} \mathrm{Cu}^{\mathrm{I}}\left(\mu_{3}-\mathrm{OH}\right) \mathbf{L}$ (blue), $\mathrm{Cu}^{\mathrm{I}} \mathrm{Cu}^{\mathrm{I}} \mathrm{Cu}^{\mathrm{I}}\left(\mu_{3}-\mathrm{OH}\right) \mathbf{L H}$ (green), and $\mathrm{Cu}^{\mathrm{I}} \mathrm{Cu}^{\mathrm{I}} \mathrm{Cu}^{\mathrm{I}}\left(\mu_{2}-\mathrm{OH}_{2}\right) \mathbf{L}$ (red) were collected at $-50{ }^{\circ} \mathrm{C}$ with an AVIII $600 \mathrm{MHz}$ instrument. 
Attempt to perform $\mathrm{H} / \mathrm{D}$ exchange of $\mathrm{Cu}^{\mathrm{I}} \mathrm{Cu}^{\mathrm{I}} \mathrm{Cu}^{\mathrm{I}}\left(\mu_{2}-\mathrm{OH}_{2}\right) \mathrm{L}$ using $\mathrm{D}_{2} \mathrm{O}$.

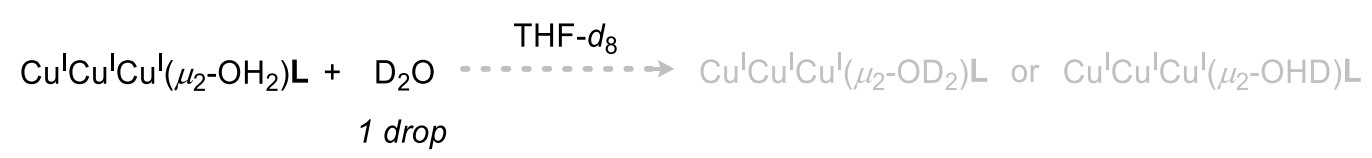

In order to confirm the singlet peak at $9.15 \mathrm{ppm}$ in Figure S21 (trace 1, blue) is from the aqua

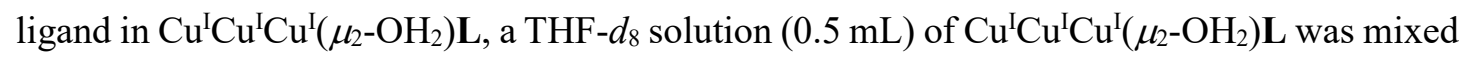
with one drop of $\mathrm{D}_{2} \mathrm{O}$. The mixture was allowed to store under $\mathrm{N}_{2}$ for five hours. There is a slight shift of the peak at $9.15 \mathrm{ppm}$ to the upfield (9.02 ppm). However, the integral of $\mu_{2}-\mathrm{OH}_{2}$ peak remains the same, suggesting no deuterium exchange between $\mathrm{Cu}^{\mathrm{I}} \mathrm{Cu}^{\mathrm{I}} \mathrm{Cu}^{\mathrm{I}}\left(\mu_{2}-\mathrm{OH}_{2}\right) \mathbf{L}$ and $\mathrm{D}_{2} \mathrm{O}$ had occurred (Figure S21, trace 2, red). This is probably due to the stable hydrogen bonding interaction between the $\mu_{2}-\mathrm{OH}_{2}$ and the ligand. The isolating environment provided by the cryptate ligand could also prevent the deuterium exchange. Moreover, the signals of the C$\mathrm{H}$ protons from the TREN 4 ligand also shifted slightly upon $\mathrm{D}_{2} \mathrm{O}$ addition, probably due to the change in solvent polarity.
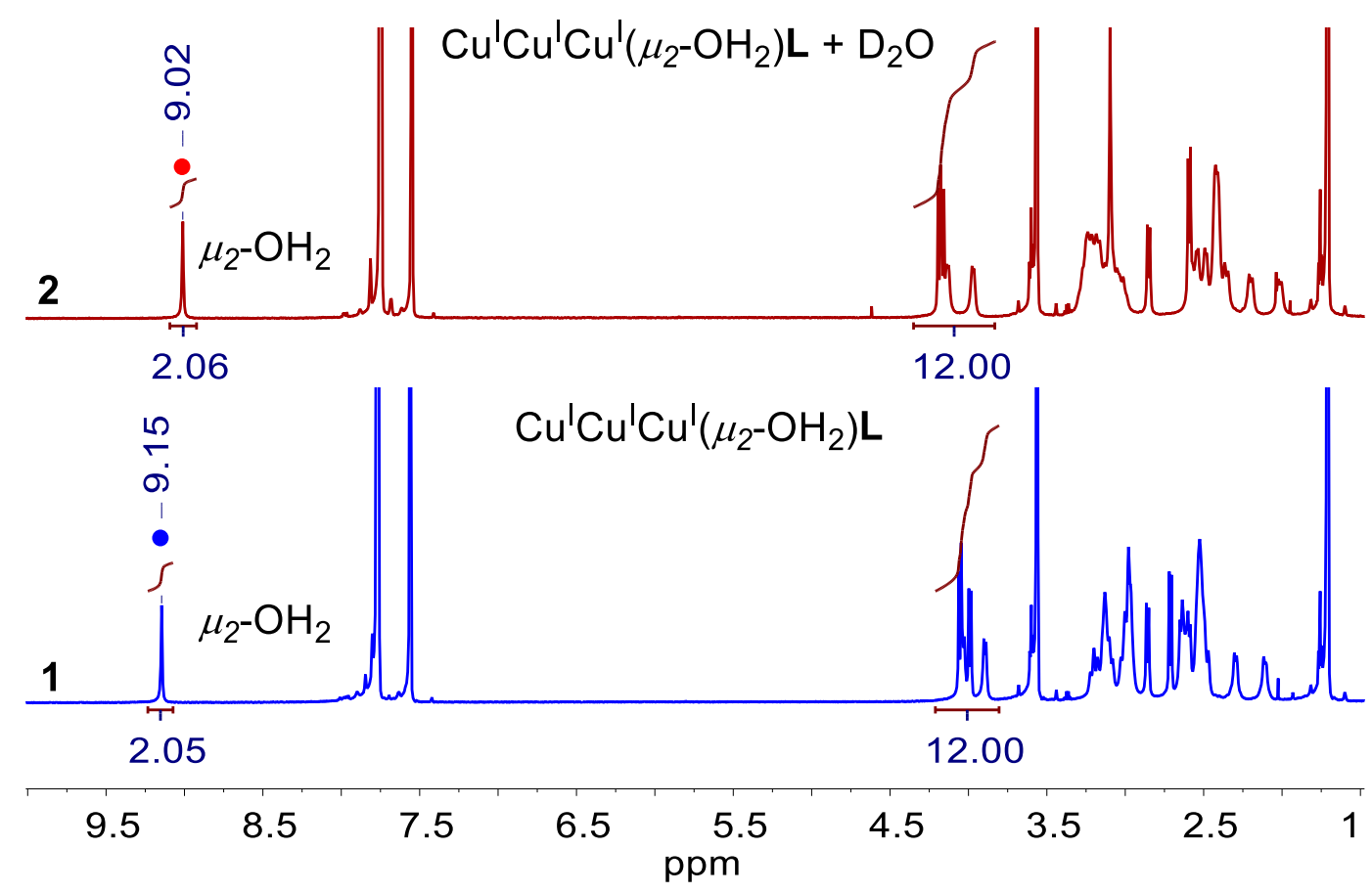

Figure S21. ${ }^{1} \mathrm{H}$ NMR of $\mathrm{Cu}^{\mathrm{I}} \mathrm{Cu}^{\mathrm{I}} \mathrm{Cu}^{\mathrm{I}}\left(\mu_{3}-\mathrm{OH}\right) \mathbf{L}$ (line 1, blue) and the mixture of $\mathrm{Cu}^{\mathrm{I}} \mathrm{Cu}^{\mathrm{I}} \mathrm{Cu}^{\mathrm{I}}\left(\mu_{3}-\mathrm{OH}\right) \mathbf{L}$ and $\mathrm{D}_{2} \mathrm{O}$ (line 2 , red) in THF- $d_{8}$.

\section{${ }^{1} \mathrm{H}$ NMR study of the reaction of $\mathrm{Cu}^{\mathrm{I}} \mathrm{Cu}^{\mathrm{I}} \mathrm{Cu}^{\mathrm{I}}\left(\mu_{3}-\mathrm{OH}\right) \mathrm{L}$ and $\left[\left(\mathrm{Et}_{2} \mathrm{O}\right)_{2} \mathrm{D}\right] \mathrm{BAr}{ }^{\mathrm{F}}{ }_{4}$.}

$\left[\mathrm{Cu}^{\mathrm{I}} \mathrm{Cu}^{\mathrm{I}} \mathrm{Cu}^{\mathrm{I}}\left(\mu_{3}-\mathrm{OH}\right) \mathbf{L}\right]\left(\mathrm{BAr}_{4}{ }_{4}\right)_{2}(5 \mathrm{mg}, 1.88 \mu \mathrm{mol})$ and $\left[\left(\mathrm{Et}_{2} \mathrm{O}\right)_{2} \mathrm{D}\right] \mathrm{BAr}_{4} \mathrm{~F}_{4}(1.9 \mathrm{mg}, 1.88 \mu \mathrm{mol})$ was mixed in $0.5 \mathrm{~mL}$ THF- $d_{8}$ under $\mathrm{N}_{2}$ and transferred to a J-Young NMR tube in the glovebox. The ${ }^{1} \mathrm{H}$ NMR sample was sent to NMR characterization. Compared to the ${ }^{1} \mathrm{H}$ NMR spectrum of $\mathrm{Cu}^{\mathrm{I}} \mathrm{Cu}^{\mathrm{I}} \mathrm{Cu}^{\mathrm{I}}\left(\mu_{2}-\mathrm{OH}_{2}\right) \mathbf{L}$, the peak at $9.15 \mathrm{ppm}(2 \mathrm{H})$ was splitted to two peaks at $9.46 \mathrm{ppm}$ and $9.15 \mathrm{ppm}$ with the integral around 0.72 and 0.48 , respectively, suggesting the formation of a mixture of $\mathrm{Cu}^{\mathrm{I}} \mathrm{Cu}^{\mathrm{I}} \mathrm{Cu}^{\mathrm{I}}\left(\mu_{2}-\mathrm{OHD}\right) \mathbf{L}$ and $\mathrm{Cu}^{\mathrm{I}} \mathrm{Cu}^{\mathrm{I}} \mathrm{Cu}^{\mathrm{I}}\left(\mu_{2}-\mathrm{OH}_{2}\right) \mathbf{L}$ in ca. 3:1 ratio (Figure S22). We proposed that the reason why the reaction afforded mixture of $\mathrm{Cu}^{\mathrm{I}} \mathrm{Cu}^{\mathrm{I}} \mathrm{Cu}^{\mathrm{I}}\left(\mu_{2}-\mathrm{OHD}\right) \mathbf{L}$ and 


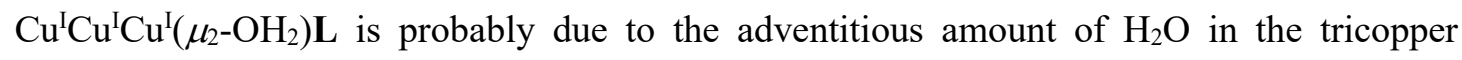
complex.

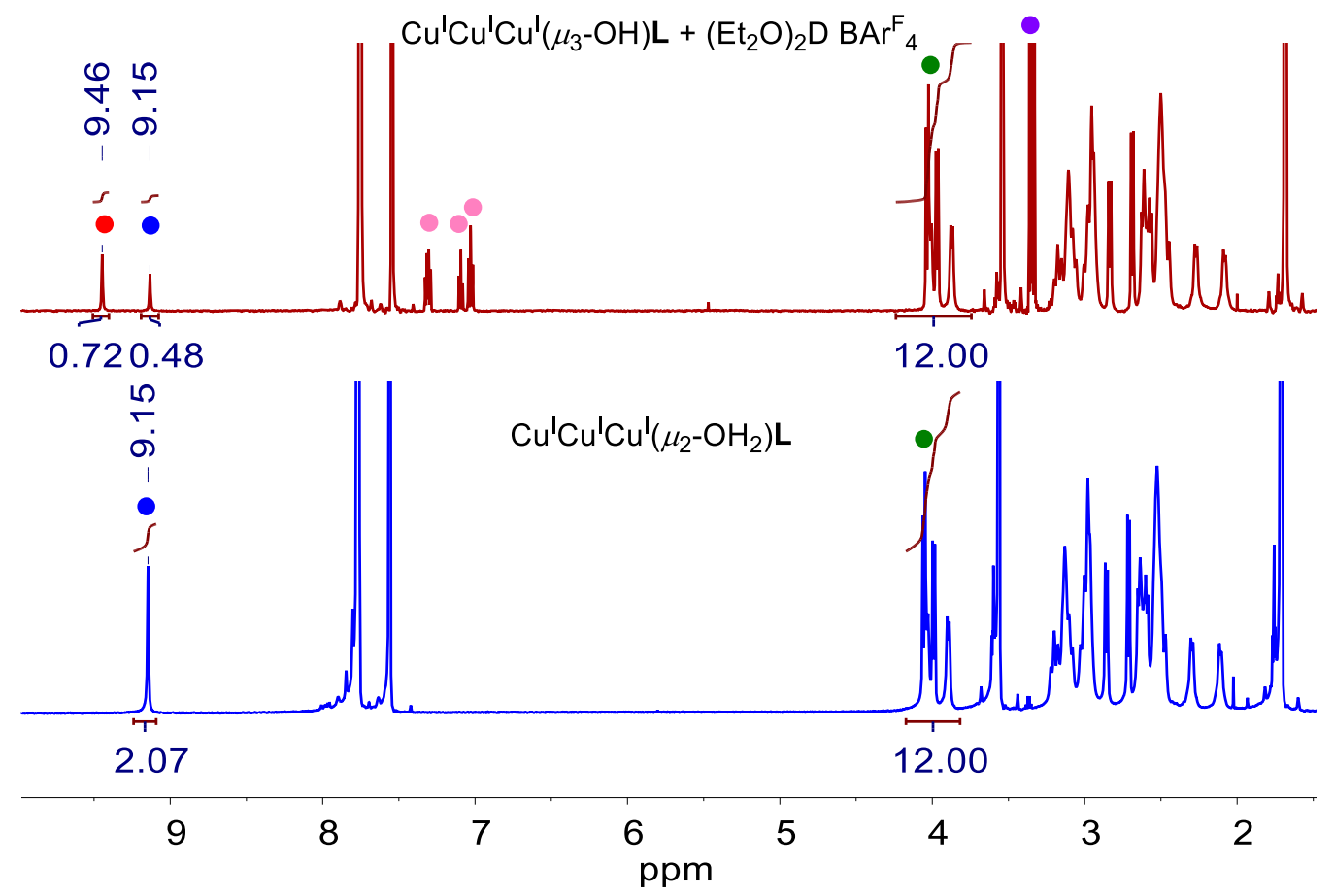

Figure S22. In situ ${ }^{1} \mathrm{H}$ NMR study of the reaction of $\mathrm{Cu}^{\mathrm{I}} \mathrm{Cu}^{\mathrm{I}} \mathrm{Cu}^{\mathrm{I}}\left(\mu_{3}-\mathrm{OH}\right) \mathbf{L}$ and $\left[\left(\mathrm{Et}_{2} \mathrm{O}\right)_{2} \mathrm{D}\right] \mathrm{BArF} 4$ in THF- $d_{8}$ (red). ${ }^{1} \mathrm{H}$ NMR of isolated $\mathrm{Cu}^{\mathrm{I}} \mathrm{Cu}^{\mathrm{I}} \mathrm{Cu}^{\mathrm{I}}\left(\mu_{2}-\mathrm{OH}_{2}\right) \mathbf{L}$ in THF- $d_{8}$ is shown in blue as a comparison. The peak marked by a blue dot is from $\mu_{2}-\mathrm{OH}_{2}$ in $\mathrm{Cu}^{\mathrm{I}} \mathrm{Cu}^{\mathrm{I}} \mathrm{Cu}^{\mathrm{I}}\left(\mu_{2}-\mathrm{OH}_{2}\right) \mathbf{L}$. The peaks marked by red dots are proposed to be from $\mathrm{Cu}^{\mathrm{I}} \mathrm{Cu}^{\mathrm{I}} \mathrm{Cu}^{\mathrm{I}}\left(\mu_{2}-\right.$ OHD)L. The peaks marked by a green dot from $4.20 \mathrm{ppm}$ to $3.80 \mathrm{ppm}$ are the standard 12 protons from the TREN 4 ligand. The peak marked by a purple dot is from diethyl ether in $\left[\left(\mathrm{Et}_{2} \mathrm{O}\right)_{2} \mathrm{D}\right] \mathrm{BArF}_{4}$. The peaks marked by pink dots are from fluorobenzene.

\section{X-ray Crystallographic Data}

The single-crystal X-ray diffraction studies were carried out on a Bruker Kappa Photon II CPAD diffractometer equipped with $\mathrm{Cu} \mathrm{K}_{\alpha}$ radiation $(\lambda=1.54178 \AA)$ for $\mathrm{Cu}^{\mathrm{II}} \mathrm{Cu}^{\mathrm{II}} \mathrm{Cu}^{\mathrm{II}}\left(\mu_{3}-\mathrm{O}\right) \mathbf{L H}$ and $\mathrm{Mo} \mathrm{K}_{\alpha}$ radiation $(\lambda=0.71073 \AA)$ for $\mathrm{Cu}^{\mathrm{I}} \mathrm{Cu}^{\mathrm{I}} \mathrm{Cu}^{\mathrm{I}}\left(\mu_{2}-\mathrm{OH}_{2}\right) \mathbf{L}$. A $0.279 \times 0.144 \times 0.128 \mathrm{~mm}$ piece of a dark greenish-yellow plate was mounted on a Cryoloop with Paratone 24EX oil for $\mathrm{Cu}^{\mathrm{II}} \mathrm{Cu}^{\mathrm{II}} \mathrm{Cu}^{\mathrm{II}}\left(\mu_{3}-\mathrm{O}\right) \mathbf{L H}$. A $0.287 \times 0.254 \times 0.216 \mathrm{~mm}$ piece of a faint blue block was mounted

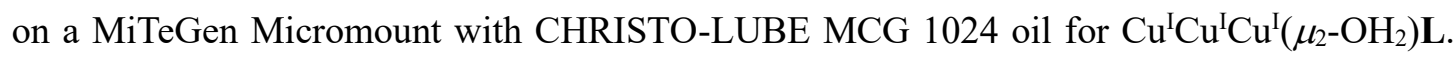
Data were collected in a nitrogen gas stream at 100(2) K using $\phi$ and $\varpi$ scans. Crystal-to- 
detector distance was $60 \mathrm{~mm}$ using variable exposure time (15s-60s for $\mathrm{Cu}^{\mathrm{II}} \mathrm{Cu}^{\mathrm{II}} \mathrm{Cu}^{\mathrm{II}}\left(\mu_{3}-\mathrm{O}\right) \mathbf{L H}$ and $2 \mathrm{~s}-5 \mathrm{~s}$ for $\left.\mathrm{Cu}^{\mathrm{I}} \mathrm{Cu}^{\mathrm{I}} \mathrm{Cu}^{\mathrm{I}}\left(\mu_{2}-\mathrm{OH}_{2}\right) \mathbf{L}\right)$ depending on $\theta$ with a scan width of $1.0^{\circ}$. The data were integrated using the Bruker SAINT software program and scaled using the SADABS software program. Solution by direct methods (SHELXT) produced a complete phasing model for refinement.

All nonhydrogen atoms were refined anisotropically by full-matrix least-squares (SHELXL2014). All hydrogen atoms were placed using a riding model. Their positions were constrained relative to their parent atom using the appropriate HFIX command in SHELXL-2014. For $\mathrm{Cu}^{\mathrm{II}} \mathrm{Cu}^{\mathrm{II}} \mathrm{Cu}^{\mathrm{II}}\left(\mu_{3}-\mathrm{O}\right) \mathbf{L H}$, due to unmodelable solvent disorder, Platon SQUEEZE was used to remove the electron density from the lattice due to the disordered solvent contribution. Solvent appeared to be Acetone. Three voids were found with approximately 594 electrons in each. Crystallographic data are summarized in Table S4.

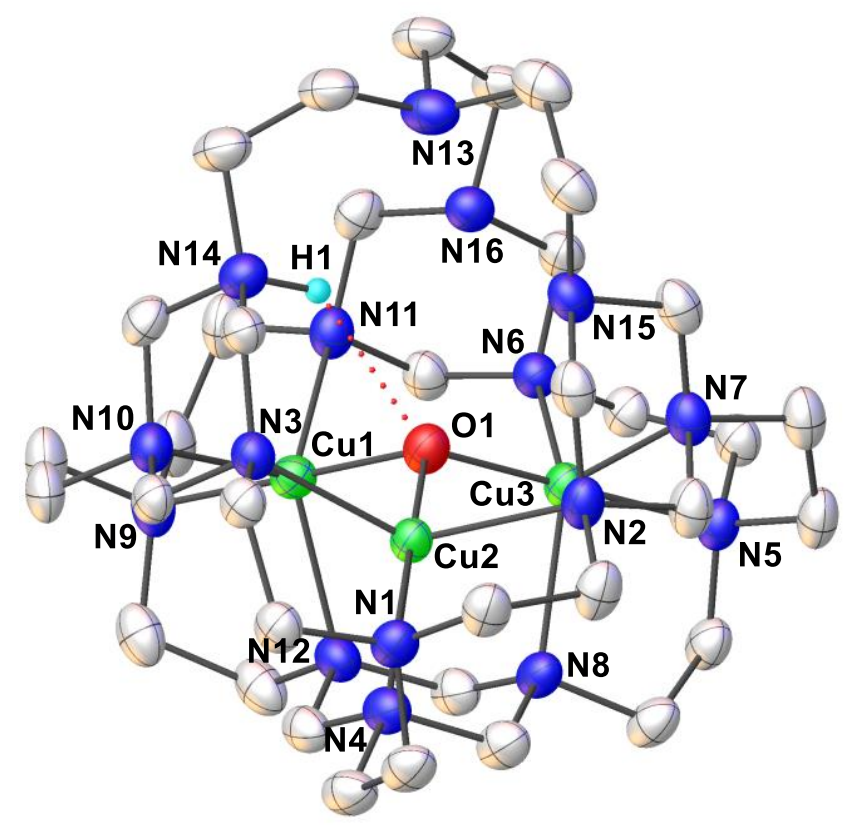

Figure S23. X-ray structure (CIF: $2111320,100 \mathrm{~K})$ of $\mathrm{Cu}^{\mathrm{II}} \mathrm{Cu}^{\mathrm{II}} \mathrm{Cu}^{\mathrm{II}}\left(\mu_{3}-\mathrm{O}\right) \mathbf{L H}$ with thermal ellipsoids of $30 \%$ probability. Hydrogen atoms on carbon, solvent molecules, and anion $\mathrm{PF}_{6}{ }^{-} / \mathrm{BF}_{4}{ }^{-}$are omitted for clarity. Selected bond lengths $(\AA)$ : Avg. $\mathrm{Cu}-\mathrm{O}=1.918(2)$, Avg. $\mathrm{Cu} \cdot \mathrm{Cu}=3.139, \mathrm{~N} 14-\mathrm{O} 1=3.159$. 


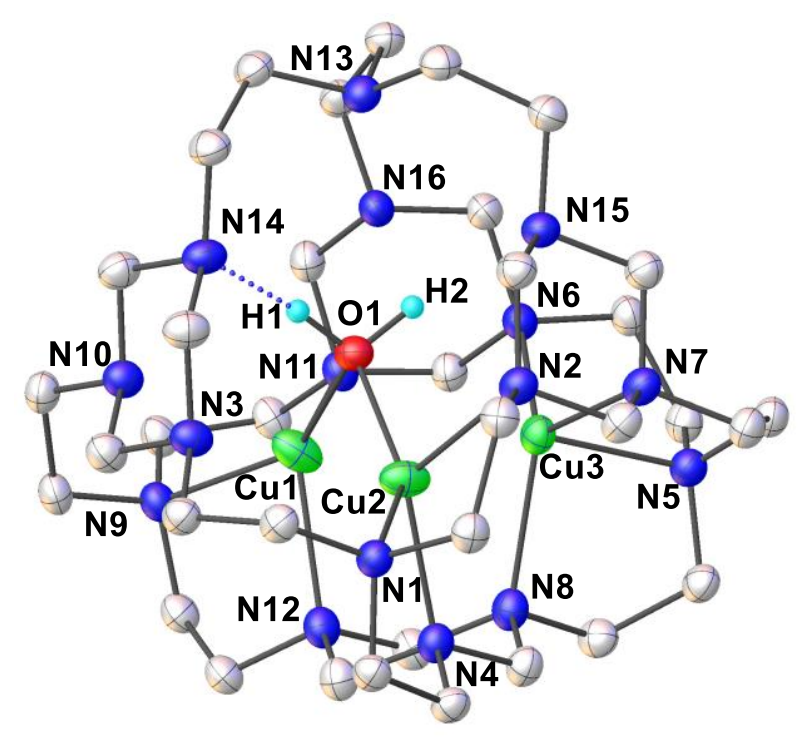

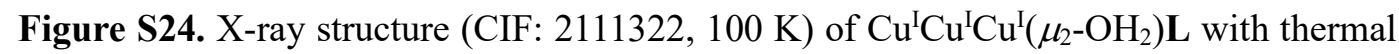
ellipsoids of $50 \%$ probability. Hydrogen atoms on carbon, solvent molecules, and anion

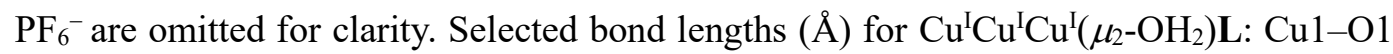
$=2.093(3), \mathrm{Cu} 2-\mathrm{O} 1=2.073(3), \mathrm{Cu} 3-\mathrm{O} 1=2.824, \mathrm{~N} 14-\mathrm{O} 1=2.597, \mathrm{Cu} 1 \cdots \mathrm{Cu} 2=3.039$, $\mathrm{Cu} 1 \cdots \mathrm{Cu} 3=3.076, \mathrm{Cu} 2 \cdots \mathrm{Cu} 3=2.972$.

Table S4: Crystal Data and Structure Refinement for $\mathrm{Cu}^{\mathrm{I}} \mathrm{Cu}^{\mathrm{I}} \mathrm{Cu}^{\mathrm{I}}\left(\mu_{2}-\mathrm{OH}_{2}\right) \mathbf{L}$ and $\mathrm{Cu}^{\mathrm{II}} \mathrm{Cu}^{\mathrm{II}} \mathrm{Cu}^{\mathrm{II}}\left(\mu_{3^{-}}\right.$ O)L

\begin{tabular}{|c|c|c|}
\hline & $\mathrm{Cu}^{\mathrm{II}} \mathrm{Cu}^{\mathrm{II}} \mathrm{Cu}^{\mathrm{II}}\left(\mu_{3}-\mathrm{O}\right) \mathbf{L H}$ & $\mathrm{Cu}^{\mathrm{I}} \mathrm{Cu}^{\mathrm{I}} \mathrm{Cu}^{\mathrm{I}}\left(\mu_{2}-\mathrm{OH}_{2}\right) \mathbf{L}$ \\
\hline $\mathrm{CCDC}$ & 2111320 & 2111322 \\
\hline $\begin{array}{l}\text { Empirical formula, } \\
\mathrm{FW}(\mathrm{g} / \mathrm{mol})\end{array}$ & $\begin{array}{l}\mathrm{C}_{36} \mathrm{H}_{73} \mathrm{~B}_{4.67} \mathrm{Cu}_{3} \mathrm{~F}_{20.66} \mathrm{~N}_{16} \mathrm{OP}_{0.33}, \\
1390.09\end{array}$ & $\begin{array}{l}\mathrm{C}_{48} \mathrm{H}_{98} \mathrm{Cu}_{3} \mathrm{~F}_{18} \mathrm{~N}_{16} \mathrm{O}_{5} \mathrm{P}_{3}, \\
1604.95\end{array}$ \\
\hline Color, habit & Dark Greenish Yellow Plate & Faint Blue Block \\
\hline Temperature $(\mathrm{K})$ & 100 & 100 \\
\hline Wavelength $(\AA)$ & 1.54178 & 0.71073 \\
\hline Crystal system, Space group & Trigonal, R -3 c & Triclinic, $\mathrm{P}-1$ \\
\hline Unit cell dimensions a $(\AA)$ & $24.0333(3)$ & $12.1309(4)$ \\
\hline $\mathrm{b}(\AA)$ & $24.0333(3)$ & $12.8761(5)$ \\
\hline c $(\AA)$ & $58.9189(13)$ & $22.1328(9)$ \\
\hline$\alpha\left(^{\circ}\right)$ & $90^{\circ}$ & $87.801(2)$ \\
\hline$\beta\left(^{\circ}\right)$ & $90^{\circ}$ & $89.4090(10)$ \\
\hline$\gamma\left(\left(^{\circ}\right)\right.$ & $120^{\circ}$ & $71.2900(10)$ \\
\hline Volume $\left(\AA^{3}\right)$ & $29472.2(10)$ & $3272.0(2)$ \\
\hline Z & 18 & 2 \\
\hline Density (calc., $\mathrm{g} / \mathrm{cm}^{-3}$ ) & 1.410 & 1.629 \\
\hline $\begin{array}{l}\text { Absorption coefficient } \\
\left(\mathrm{mm}^{-1}\right)\end{array}$ & 2.110 & 1.148 \\
\hline$F(000)$ & 12785 & 1664 \\
\hline
\end{tabular}




\begin{tabular}{|c|c|c|}
\hline $\begin{array}{l}\text { Theta range for data } \\
\text { collection }\left(^{\circ}\right)\end{array}$ & 3.676 to 74.520 & 2.926 to 28.363 \\
\hline Index ranges & $\begin{array}{l}-30<=\mathrm{h}<=29, \quad-28<=\mathrm{k}<=30, \\
72<=\mathrm{l}<=73\end{array}$ & $\begin{array}{l}-16<=\mathrm{h}<=16, \quad-17<=\mathrm{k}<=17, \\
-29<=\mathrm{l}<=29\end{array}$ \\
\hline Reflections collected & 112028 & 170318 \\
\hline Independent reflections, $\mathrm{R}_{\text {int }}$ & $\begin{array}{l}6699[\mathrm{R}(\text { int })=0.0577, \\
\mathrm{R}(\text { sigma })=0.0179]\end{array}$ & $\begin{array}{l}16298[\mathrm{R}(\mathrm{int})=0.0295, \\
\mathrm{R}(\text { sigma })=0.0152]\end{array}$ \\
\hline Completeness to $2 \theta_{\max }(\%)$ & 100.0 & 99.8 \\
\hline Absorption correction & $\begin{array}{ll}\text { Semi-empirical } & \text { from } \\
\text { equivalents } & \end{array}$ & $\begin{array}{ll}\text { Semi-empirical } & \text { from } \\
\text { equivalents } & \end{array}$ \\
\hline Refinement method & Full-matrix least-squares on $\mathrm{F}^{2}$ & $\begin{array}{l}\text { Full-matrix least-squares on } \\
\mathrm{F}^{2}\end{array}$ \\
\hline $\begin{array}{ll}\text { Data } / & \text { restraints } / \\
\text { parameters } & \\
\end{array}$ & $6699 / 821 / 716$ & $16298 / 135 / 911$ \\
\hline Goodness-of-fit & 1.046 & 1.044 \\
\hline $\begin{array}{l}\text { Final } R \text { indices } \\
{[\mathrm{I}>2 \operatorname{sigma}(\mathrm{I})]}\end{array}$ & $\mathrm{R} 1=0.0599, \mathrm{wR} 2=0.1753$ & $\mathrm{R} 1=0.0340, \mathrm{wR} 2=0.0820$ \\
\hline $\begin{array}{l}\text { Largest diff. peak and hole } \\
\left(e \cdot \AA^{-3}\right)\end{array}$ & 1.432 and -1.060 & 0.960 and -0.683 \\
\hline
\end{tabular}

\section{UV-vis spectro-electrochemistry Studies Details}

A

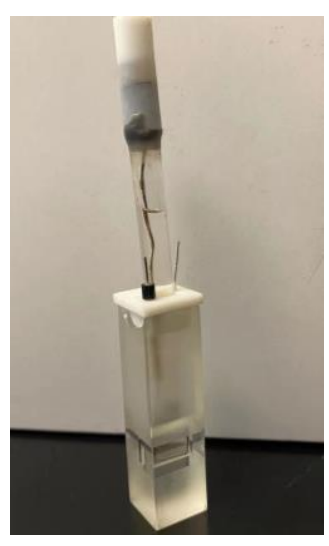

B

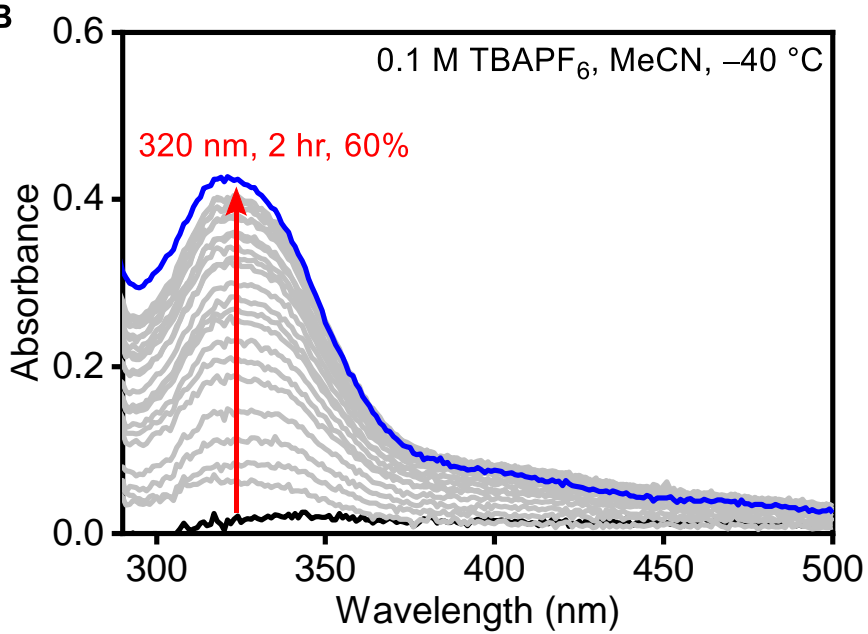

Figure S25. UV-vis spectrum during the electrolysis of the mixture of $\mathrm{Cu}^{\mathrm{II}} \mathrm{Cu}^{\mathrm{I}} \mathrm{Cu}^{\mathrm{I}}\left(\mu_{3}\right.$ $\mathrm{OH}) \mathbf{L}$ and $\left[\left(\mathrm{Et}_{2} \mathrm{O}\right)_{2} \mathrm{H}\right] \mathrm{BAr}_{4}{ }_{4}$ in $0.1 \mathrm{M} \mathrm{TBAPF}_{6} \mathrm{MeCN}$ electrolyte after subtracting the spectrum of leftover $\mathrm{Cu}^{\mathrm{II}} \mathrm{Cu}^{\mathrm{I}} \mathrm{Cu}^{\mathrm{I}}\left(\mu_{3}-\mathrm{OH}\right) \mathbf{L}$.

Spectroelectrochemical experiment was performed in a $1 \mathrm{~mm}$ thin layer quartz glass spectroelectrochemical cell with an Agilent Cary 60 spectrophotometer and a Bio-Logic SAS SP-50 potentiostat. The cell was assembled with a conventional three-electrode system: a 
platinum mesh working electrode, a platinum wire counter electrode, and the $\mathrm{Ag} / \mathrm{AgNO}_{3}$ reference electrode. The in situ UV-vis spectrum was recorded in the range of 200-1000nm every 15 seconds. All the operations are under $\mathrm{N}_{2}$ protection.

\section{Reduction of $\mathrm{Cu}^{\mathrm{II}} \mathrm{Cu}^{\mathrm{I}} \mathrm{Cu}^{\mathrm{I}}\left(\mu_{3}-\mathrm{OH}\right) \mathrm{L}$ and $\left[\left(\mathrm{Et}_{2} \mathrm{O}\right)_{2} \mathrm{H}\right] \mathrm{BAr}^{\mathrm{F}}{ }_{4}$ mixture by bulk electrolysis.}

The spectroelectrochemical cell was assembled as shown in Figure S25A and was transferred to the UV-Vis spectrometer under $\mathrm{N}_{2}$. A MeCN solution of tetra-n-butylammonium hexafluorophosphate electrolyte $(0.1 \mathrm{M}, 1 \mathrm{~mL})$ was injected to the cell for background collection. The $1 \mathrm{~mL}$ electrolyte in the cell was transferred to a mixture of $\mathrm{Cu}^{\mathrm{II}} \mathrm{Cu}^{\mathrm{I}} \mathrm{Cu}^{\mathrm{I}}\left(\mu_{3}-\mathrm{OH}\right) \mathbf{L}$ $(4.1 \mathrm{mg}, 0.3 \mu \mathrm{mol})$ and $\left[\left(\mathrm{Et}_{2} \mathrm{O}\right)_{2} \mathrm{H}\right] \mathrm{BAr}_{4} \mathrm{~F}_{4}(3 \mathrm{mg}, 3 \mu \mathrm{mol})$. After the solids were fully dissolved, the obtained solution was transferred back to the spectroelectrochemical cell. The electrolysis was carried out at $-40{ }^{\circ} \mathrm{C}$ with a constant current $(0.1 \mathrm{~mA})$. The in situ UV-vis spectrum was recorded in the range of 200-1000nm every 15 seconds (Figure S25B).

\section{Electrochemistry details}

Cyclic voltammetry was performed under $\mathrm{N}_{2}$ in $0.1 \mathrm{M}$ TBAPF6 MeCN electrolyte by BioLogic SAS SP-50 potentiostat. The electrochemical cell was assembled with a conventional three-electrode system: glassy carbon $\left(0.07 \mathrm{~cm}^{2}\right)$ as working electrode, platinum wire as the counter electrode, and $\mathrm{Ag} / \mathrm{AgNO}_{3}(0.01 \mathrm{M})$ as the reference electrode.

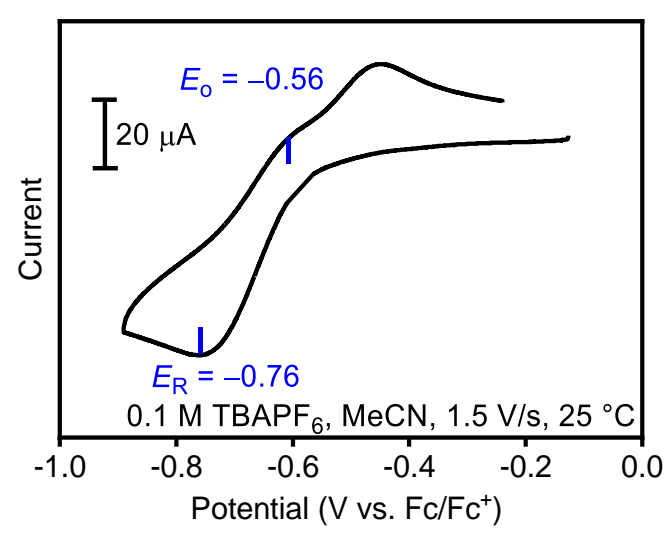

Figure S26. CV of $\mathrm{Cu}^{\mathrm{II}} \mathrm{Cu}^{\mathrm{II}} \mathrm{Cu}^{\mathrm{II}}\left(\mu_{3}-\mathrm{O}\right) \mathbf{L H}$ in $0.1 \mathrm{M} \mathrm{TBAPF}_{6} \mathrm{MeCN}$ electrolyte at $25^{\circ} \mathrm{C}$ with the scan rate of $1.5 \mathrm{~V} / \mathrm{s}$. 


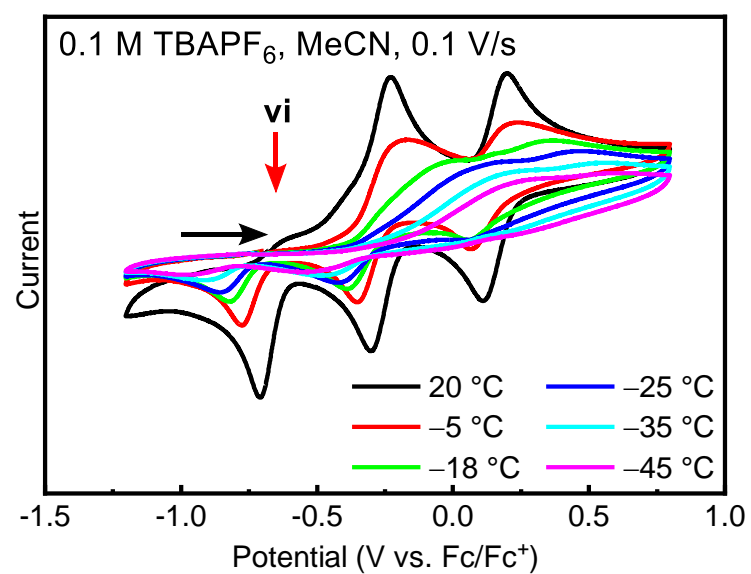

Figure S27. Temperature-dependent $\mathrm{CV}$ of $\mathrm{Cu}^{\mathrm{I}} \mathrm{Cu}^{\mathrm{I}} \mathrm{Cu}^{\mathrm{I}}\left(\mu_{2}-\mathrm{OH}_{2}\right) \mathbf{L}$ in $0.1 \mathrm{M}^{\mathrm{TBAPF}} 6$ $\mathrm{MeCN}$ electrolyte at $0.1 \mathrm{~V} / \mathrm{s}$ scan rate.

Interestingly, peak vi is already present during the first scan, indicating a small amount of $\mathrm{Cu}^{\mathrm{I}} \mathrm{Cu}^{\mathrm{I}} \mathrm{Cu}^{\mathrm{I}}\left(\mu_{3}-\mathrm{OH}\right) \mathbf{L H}$ can be generated from $\mathrm{Cu}^{\mathrm{I}} \mathrm{Cu}^{\mathrm{I}} \mathrm{Cu}^{\mathrm{I}}\left(\mu_{3}-\mathrm{OH}_{2}\right) \mathbf{L}$ via IPT equilibrium (Manuscript, Figure 6C). In contrast to the increased peak height of vi at $-40{ }^{\circ} \mathrm{C}$, anodic wave vi disappears during consecutive $\mathrm{CV}$ scans at $-40{ }^{\circ} \mathrm{C}$ (Figure S27), suggesting that $\mathrm{Cu}^{\mathrm{I}} \mathrm{Cu}^{\mathrm{I}} \mathrm{Cu}^{\mathrm{I}}\left(\mu_{3}-\mathrm{OH}\right) \mathbf{L H}$ is not an intermediate during the conversion of $\mathrm{Cu}^{\mathrm{II}} \mathrm{Cu}^{\mathrm{I}} \mathrm{Cu}^{\mathrm{I}}\left(\mu_{3}-\mathrm{OH}\right) \mathbf{L H}$ to $\mathrm{Cu}^{\mathrm{I}} \mathrm{Cu}^{\mathrm{I}} \mathrm{Cu}^{\mathrm{I}}\left(\mu_{2}-\mathrm{OH}_{2}\right) \mathbf{L}$. Instead, the $\mathrm{Cu}^{\mathrm{I}} \mathrm{Cu}^{\mathrm{I}} \mathrm{Cu}^{\mathrm{I}}\left(\mu_{3}-\mathrm{OH}\right) \mathbf{L H}$ observed at room temperature presumably forms through IPT equilibrium after $\mathrm{Cu}^{\mathrm{I}} \mathrm{Cu}^{\mathrm{I}} \mathrm{Cu}^{\mathrm{I}}\left(\mu_{3}-\mathrm{OH}_{2}\right) \mathbf{L}$ is produced at the electrode surface. This IPT process is slowed significantly at $-40{ }^{\circ} \mathrm{C}$; therefore, less $\mathrm{Cu}^{\mathrm{I}} \mathrm{Cu}^{\mathrm{I}} \mathrm{Cu}^{\mathrm{I}}\left(\mu_{3}-\mathrm{OH}\right) \mathbf{L H}$ is observed (peak vi) by $\mathrm{CV}$ at low temperature. 

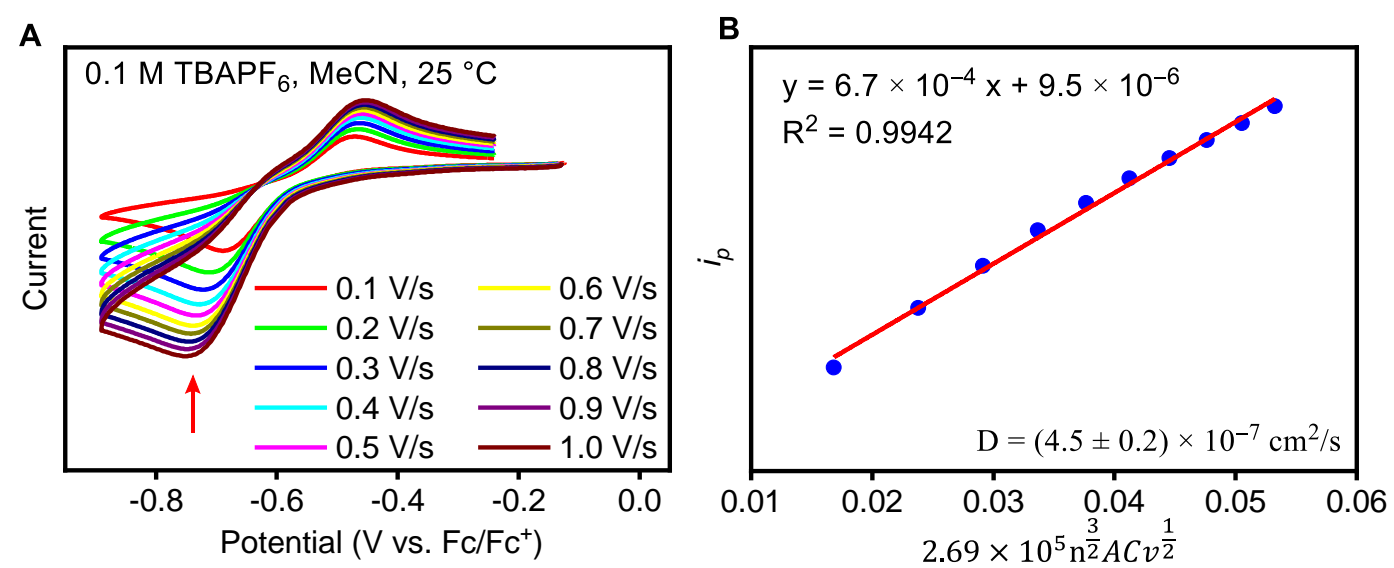

Figure S28. (A) Scan rate dependent $\mathrm{CV}$ of $\mathrm{Cu}^{\mathrm{II}} \mathrm{Cu}^{\mathrm{II}} \mathrm{Cu}^{\mathrm{II}}\left(\mu_{3}-\mathrm{O}\right) \mathbf{L H}$ in $0.1 \mathrm{M} \mathrm{TBAPF}_{6}$ $\mathrm{MeCN}$ electrolyte at $25^{\circ} \mathrm{C}$. (B) Randles-Sevcik plot with the cathodic wave in A. RandlesSevcik equation expresses as:

$$
i_{p}=0.4463 n F A C\left(\frac{n F v D}{R T}\right)^{\frac{1}{2}}
$$

Eq. 1

where $\mathrm{n}$ is number of electrons transferred in the redox event ( 2 in this case), $F$ is Faraday Constant $(96485 \mathrm{C} / \mathrm{mol}), A$ is electrode area $\left(0.07 \mathrm{~cm}^{2}\right), C$ is substrate concentration $\left(10^{-6}\right.$ $\mathrm{mol} / \mathrm{mL}), D$ is diffusion coefficient $\left(\mathrm{cm}^{2} / \mathrm{s}\right), \mathrm{v}$ is scan rate $(\mathrm{V} / \mathrm{s}), R$ is Gas constant $(8.314$ $\mathrm{J} / \mathrm{mol} \mathrm{K}), T$ is temperature $(298 \mathrm{~K})$. The Eq. 1 can be simplified as follows $(298 \mathrm{~K})$ :

$$
i_{p}=2.69 \times 10^{5} n^{\frac{2}{3}} A D^{\frac{1}{2}} C v^{\frac{1}{2}}
$$

According to the fitting, the diffusion coefficient for $\mathrm{Cu}^{\mathrm{II}} \mathrm{Cu}^{\mathrm{II}} \mathrm{Cu}^{\mathrm{II}}\left(\mu_{3}-\mathrm{O}\right) \mathbf{L H}$ is $(4.5 \pm$ $0.2) \times 10^{-7} \mathrm{~cm}^{2} / \mathrm{s}$.

\section{Cyclic voltammetry simulation for $\mathrm{Cu}^{\mathrm{I}} \mathrm{Cu}^{\mathrm{I}} \mathrm{Cu}^{\mathrm{I}}\left(\mu_{2}-\mathrm{OH}_{2}\right) \mathrm{L}$}

All simulated CVs were calculated using DigiElch 8 software. ${ }^{7}$ Symmetry factors/transfer coefficients ( $\alpha$ values) were set to 0.5 for all ET steps. The redox potential of each redox couple was locked with known values from the experimental CV. The temperature is set to $298 \mathrm{~K}$. The initial diffusion coefficient $(D)$ for all the tricopper complexes was set to $10^{-6} \mathrm{~cm}^{2} / \mathrm{s}$, which is closed to the reported value for the tricopper complex with $\mathbf{T R E N} \mathbf{N}_{4}$ ligand: $\mathrm{Cu}^{\mathrm{I}} \mathrm{Cu}^{\mathrm{I}} \mathrm{Cu}^{\mathrm{I}}\left(\mu_{3}-\mathrm{OH}\right) \mathbf{L}$ $/ \mathrm{Cu}^{\mathrm{II}} \mathrm{Cu}^{\mathrm{I}} \mathrm{Cu}^{\mathrm{I}}\left(\mu_{3}-\mathrm{OH}\right) \mathbf{L}\left(9.4 \times 10^{-7} \mathrm{~cm}^{2} / \mathrm{s}\right)$ and $\mathrm{Cu}^{\mathrm{II}} \mathrm{Cu}^{\mathrm{I}} \mathrm{Cu}^{\mathrm{I}}\left(\mu_{3}-\mathrm{OH}\right) \mathbf{L} / \mathrm{Cu}^{\mathrm{II}} \mathrm{Cu}^{\mathrm{II}} \mathrm{Cu}^{\mathrm{I}}\left(\mu_{3}-\mathrm{OH}\right) \mathbf{L}(1.4$ $\left.\times 10^{-6} \mathrm{~cm}^{2} / \mathrm{s}\right)$. The diffusion coefficient for $\mathrm{Cu}^{\mathrm{II}} \mathrm{Cu}^{\mathrm{II}} \mathrm{Cu}^{\mathrm{II}}\left(\mu_{3}-\mathrm{OH}\right) \mathbf{L H}, \mathrm{Cu}^{\mathrm{II}} \mathrm{Cu}^{\mathrm{II}} \mathrm{Cu}^{\mathrm{I}}\left(\mu_{3}-\mathrm{OH}\right) \mathbf{L H}$, $\mathrm{Cu}^{\mathrm{II}} \mathrm{Cu}^{\mathrm{I}} \mathrm{Cu}^{\mathrm{I}}\left(\mu_{3}-\mathrm{OH}\right) \mathbf{L H}$, and $\mathrm{Cu}^{\mathrm{I}} \mathrm{Cu}^{\mathrm{I}} \mathrm{Cu}^{\mathrm{I}}\left(\mu_{3}-\mathrm{OH}\right) \mathbf{L H}$ are set to be 1:1 ratio locked. The diffusion coefficient for $\mathrm{Cu}^{\mathrm{II}} \mathrm{Cu}^{\mathrm{I}} \mathrm{Cu}^{\mathrm{I}}\left(\mu_{2}-\mathrm{OH}_{2}\right) \mathbf{L}, \mathrm{Cu}^{\mathrm{I}} \mathrm{Cu}^{\mathrm{I}} \mathrm{Cu}^{\mathrm{I}}\left(\mu_{2}-\mathrm{OH}_{2}\right) \mathbf{L H}$ are set to be 1:1 ratio. This restriction avoids unrealistic variation of the diffusion coefficients and is reasonable due to the minimal change in size for the six tricopper complex. The initial heterogeneous electron transfer rate $\left(k_{\mathrm{ET}}\right)$ for all the tricopper complexes was set to $0.01 \mathrm{~cm}^{2} / \mathrm{s}$, which is closed to the reported value for the tricopper complex with $\mathbf{T R E N}_{4}$ ligand $\left(0.008 \mathrm{~cm}^{2} / \mathrm{s}\right)$. In the beginning, the diffusion coefficients are allowed to vary to match the current intensity from the experimental $\mathrm{CV}$, while all the other parameters are locked. Then, the diffusion coefficients are locked, and the equilibrium constants and rate constants for the chemical reactions are allowed to vary. 
After the simulated curve obtained its best fit, the equilibrium constants and rate constants for the chemical reactions were locked, and all the heterogeneous electron transfer rates were optimized to adjust the position for each wave. Finally, the equilibrium constant and rate constant for the chemical reactions were optimized again to find the final best fit of the simulated curve.

Heterogeneous/Electrochemical Reactions:

\begin{tabular}{|c|c|c|c|}
\hline Oxidized Species & Reduced Species & $E^{0} / \mathrm{V}$ vs. Fc & $k_{\mathrm{ET}} / \mathrm{cm} \mathrm{s}^{-1}$ \\
\hline $\mathrm{Cu}^{\mathrm{II}} \mathrm{Cu}^{\mathrm{II}} \mathrm{Cu}^{\mathrm{II}}\left(\mu_{3}-\mathrm{OH}\right) \mathbf{L H}$ & $\mathrm{Cu}^{\mathrm{II}} \mathrm{Cu}^{\mathrm{II}} \mathrm{Cu}^{\mathrm{I}}\left(\mu_{3}-\mathrm{OH}\right) \mathbf{L H}$ & $0.17^{\mathrm{a}}$ & $0.0085^{\mathrm{b}}$ \\
\hline $\mathrm{Cu}^{\mathrm{II}} \mathrm{Cu}^{\mathrm{II}} \mathrm{Cu}^{\mathrm{I}}\left(\mu_{3}-\mathrm{OH}\right) \mathbf{L H}$ & $\mathrm{Cu}^{\mathrm{II}} \mathrm{Cu}^{\mathrm{I}} \mathrm{Cu}^{\mathrm{I}}\left(\mu_{3}-\mathrm{OH}\right) \mathbf{L} \mathbf{H}$ & $-0.25^{\mathrm{a}}$ & $0.012^{\mathrm{b}}$ \\
\hline $\mathrm{Cu}^{\mathrm{II}} \mathrm{Cu}^{\mathrm{I}} \mathrm{Cu}^{\mathrm{I}}\left(\mu_{3}-\mathrm{OH}\right) \mathbf{L H}$ & $\mathrm{Cu}^{\mathrm{I}} \mathrm{Cu}^{\mathrm{I}} \mathrm{Cu}^{\mathrm{I}}\left(\mu_{3}-\mathrm{OH}\right) \mathbf{L H}$ & $-0.66^{\mathrm{a}}$ & $0.0098^{b}$ \\
\hline $\mathrm{Cu}^{\mathrm{II}} \mathrm{Cu}^{\mathrm{I}} \mathrm{Cu}^{\mathrm{I}}\left(\mu_{2}-\mathrm{OH}_{2}\right) \mathbf{L}$ & $\mathrm{Cu}^{\mathrm{I}} \mathrm{Cu}^{\mathrm{I}} \mathrm{Cu}^{\mathrm{I}}\left(\mu_{2}-\mathrm{OH}_{2}\right) \mathbf{L}$ & $-0.30^{\mathrm{c}}$ & $0.012^{\mathrm{b}}$ \\
\hline \multicolumn{4}{|c|}{ Homogeneous/Chemical Reactions: } \\
\hline Reactant & Product & $K_{\mathrm{eq}}$ & $k_{\text {forward }}$ \\
\hline $\mathrm{Cu}^{\mathrm{II}} \mathrm{Cu}^{\mathrm{I}} \mathrm{Cu}^{\mathrm{I}}\left(\mu_{3}-\mathrm{OH}\right) \mathbf{L H}$ & $\mathrm{Cu}^{\mathrm{II}} \mathrm{Cu}^{\mathrm{I}} \mathrm{Cu}^{\mathrm{I}}\left(\mu_{2}-\mathrm{OH}_{2}\right) \mathbf{L}$ & $6.5 \times 10^{-6 b}$ & $>256^{b}$ \\
\hline $\mathrm{Cu}^{\mathrm{I}} \mathrm{Cu}^{\mathrm{I}} \mathrm{Cu}^{\mathrm{I}}\left(\mu_{3}-\mathrm{OH}\right) \mathbf{L H}$ & $\mathrm{Cu}^{\mathrm{I}} \mathrm{Cu}^{\mathrm{I}} \mathrm{Cu}^{\mathrm{I}}\left(\mu_{2}-\mathrm{OH}_{2}\right) \mathbf{L}$ & $8.8^{\mathrm{b}}$ & $0.022^{\mathrm{d}}$ \\
\hline
\end{tabular}

Table S5. CV simulation parameters for stepwise PT-ET mechanisms. ${ }^{\text {a }}$ obtained from experimental $\mathrm{CV} .{ }^{\mathrm{b}}$ : obtained from simulating and fitting the experimental $\mathrm{CV}$. The range is obtained by FitSpace analysis. ${ }^{c}$ : related to other parameter and cannot be varied independently. ${ }^{\mathrm{d}}$ : fixed value from kinetic experiment.

A

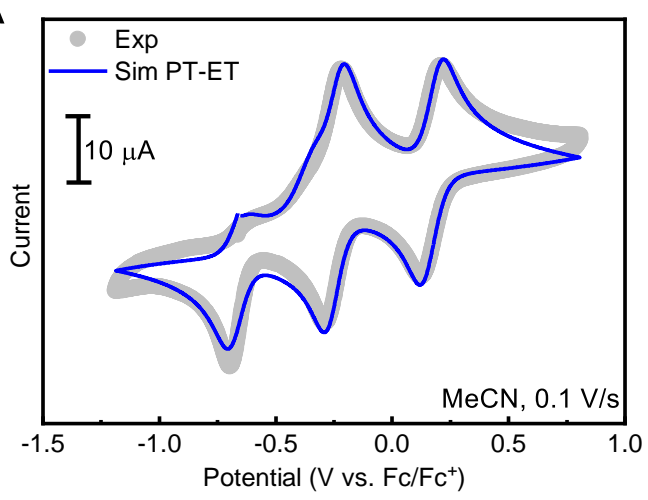

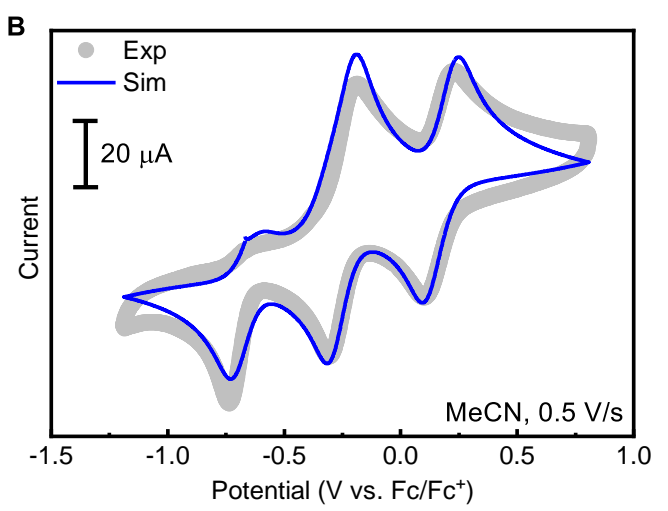

Figure S29. (A) Experimental (thick pink curve) and simulated (thin black curve) CVs of a $1 \mathrm{mM}$ solution of $\mathrm{Cu}^{\mathrm{I}} \mathrm{Cu}^{\mathrm{I}} \mathrm{Cu}^{\mathrm{I}}\left(\mu_{2}-\mathrm{OH}_{2}\right) \mathbf{L}$ at a scan rate of $0.1 \mathrm{~V} / \mathrm{s}$ with a PT-ET mechanism. (B) Experimental (thick pink curve) and simulated (thin black curve) CVs at a scan rate of $0.5 \mathrm{~V} / \mathrm{s}$ with the same parameters in (A) and a PT-ET mechanism. 
Heterogeneous/Electrochemical Reactions:

\begin{tabular}{|c|c|c|c|}
\hline Oxidized Species & Reduced Species & $E^{0} / \mathrm{V}$ vs. Fc & $k_{\mathrm{ET}} / \mathrm{cm} \mathrm{s}^{-1}$ \\
\hline $\mathrm{Cu}^{\mathrm{II}} \mathrm{Cu}^{\mathrm{II}} \mathrm{Cu}^{\mathrm{II}}\left(\mu_{3}-\mathrm{OH}\right) \mathbf{L H}$ & $\mathrm{Cu}^{\mathrm{II}} \mathrm{Cu}^{\mathrm{II}} \mathrm{Cu}^{\mathrm{I}}\left(\mu_{3}-\mathrm{OH}\right) \mathbf{L H}$ & $0.17^{\mathrm{a}}$ & $0.0085^{\mathrm{b}}$ \\
\hline $\mathrm{Cu}^{\mathrm{II}} \mathrm{Cu}^{\mathrm{II}} \mathrm{Cu}^{\mathrm{I}}\left(\mu_{3}-\mathrm{OH}\right) \mathbf{L} \mathbf{H}$ & $\mathrm{Cu}^{\mathrm{II}} \mathrm{Cu}^{\mathrm{I}} \mathrm{Cu}^{\mathrm{I}}\left(\mu_{3}-\mathrm{OH}\right) \mathbf{L H}$ & $-0.25^{\mathrm{a}}$ & $0.012^{\mathrm{b}}$ \\
\hline $\mathrm{Cu}^{\mathrm{II}} \mathrm{Cu}^{\mathrm{I}} \mathrm{Cu}^{\mathrm{I}}\left(\mu_{3}-\mathrm{OH}\right) \mathbf{L} \mathbf{H}$ & $\mathrm{Cu}^{\mathrm{I}} \mathrm{Cu}^{\mathrm{I}} \mathrm{Cu}^{\mathrm{I}}\left(\mu_{3}-\mathrm{OH}\right) \mathbf{L} \mathbf{H}$ & $-0.66^{\mathrm{a}}$ & $0.0098^{\mathrm{b}}$ \\
\hline $\mathrm{Cu}^{\mathrm{II}} \mathrm{Cu}^{\mathrm{I}} \mathrm{Cu}^{\mathrm{I}}\left(\mu_{3}-\mathrm{OH}\right) \mathbf{L H}$ & $\mathrm{Cu}^{\mathrm{I}} \mathrm{Cu}^{\mathrm{I}} \mathrm{Cu}^{\mathrm{I}}\left(\mu_{2}-\mathrm{OH}_{2}\right) \mathbf{L}$ & $-0.38^{\mathrm{c}}$ & $0.012^{\mathrm{b}}$ \\
\hline \multicolumn{4}{|c|}{ Homogeneous/Chemical Reactions: } \\
\hline Reactant & Product & $K_{\text {eq }}$ & $k_{\text {forward }}$ \\
\hline $\mathrm{Cu}^{\mathrm{I}} \mathrm{Cu}^{\mathrm{I}} \mathrm{Cu}^{\mathrm{I}}\left(\mu_{3}-\mathrm{OH}\right) \mathbf{L H}$ & $\mathrm{Cu}^{\mathrm{I}} \mathrm{Cu}^{\mathrm{I}} \mathrm{Cu}^{\mathrm{I}}\left(\mu_{2}-\mathrm{OH}_{2}\right) \mathbf{L}$ & $8.8^{\mathrm{b}}$ & $0.021^{\mathrm{d}}$ \\
\hline
\end{tabular}

Table S6. CV simulation parameters for concerted mechanisms. ${ }^{\text {a: }}$ obtained from experimental CV. ${ }^{\text {b: }}$ fixed value from simulating and fitting the experimental $\mathrm{CV}$ with stepwise mechanism. ${ }^{\text {c: }}$ related to other parameter and cannot be varied independently. ${ }^{\mathrm{d}}$ : fixed value from kinetic experiment.

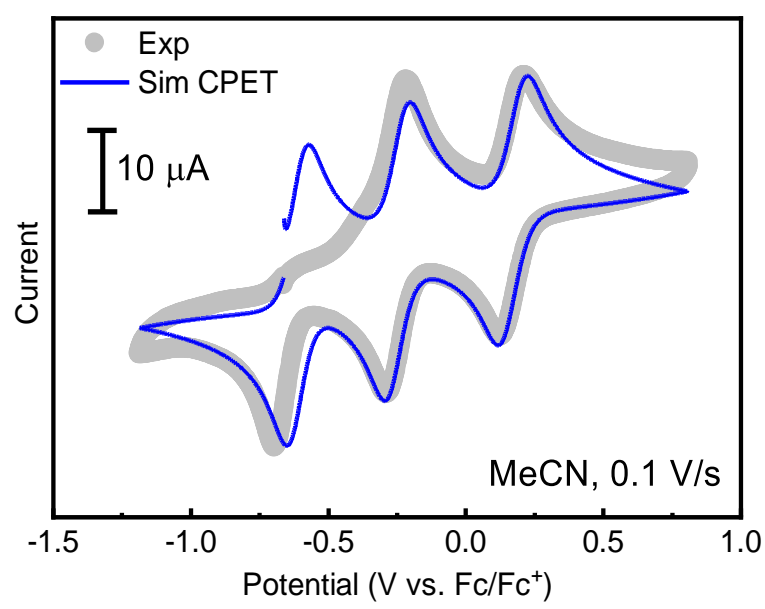

Figure S30. (A) Experimental (thick pink curve) and simulated (thin black curve) CVs of a $1 \mathrm{mM}$ solution of $\mathrm{Cu}^{\mathrm{I}} \mathrm{Cu}^{\mathrm{I}} \mathrm{Cu}^{\mathrm{I}}\left(\mu_{2}-\mathrm{OH}_{2}\right) \mathbf{L}$ at a scan rate of $0.1 \mathrm{~V} / \mathrm{s}$ with a CPET mechanism.

\section{Thermodynamic exclusionary argument}

Thermodynamic exclusion arguments against the sequential mechanisms are often used in PCET mechanism determination. ${ }^{89}$ With the assumption of PT-ET mechanism (Scheme S1), the observed rate constant was derived as Eq. 3 by steady-state approximation:

$$
k_{P T E T}=\frac{k_{P T} k_{E T}}{k_{-P T}+k_{E T}}
$$

where $k_{\mathrm{PTET}}=133 \mathrm{M}^{-1} \mathrm{~s}^{-1}, \mathrm{~K}_{\mathrm{eq}}=k_{\mathrm{PT}} / k_{-\mathrm{PT}}=6.5 \times 10^{-6}$. When $k_{-\mathrm{PT}} \gg k_{\mathrm{ET}}$, Eq. 3 can be written as Eq. 4: 


$$
k_{P T E T} \approx \frac{k_{P T}}{k_{-P T}} k_{E T}
$$

where the $k_{\mathrm{ET}}$ can be calculated as $2.0 \times 10^{7} \mathrm{M}^{-1} \mathrm{~s}^{-1}$. When $k_{-\mathrm{PT}} \ll k_{\mathrm{ET}}$, Eq. 3 can be written as Eq. 5:

$$
k_{P T E T} \approx k_{P T}
$$

Eq. 5

where the $k_{\text {-PT }}$ can be calculated as $2.0 \times 10^{7} \mathrm{M}^{-1} \mathrm{~s}^{-1}$.

In each case, the calculated rate constant is below the diffusion limit, which cannot be used to determine the mechanism.

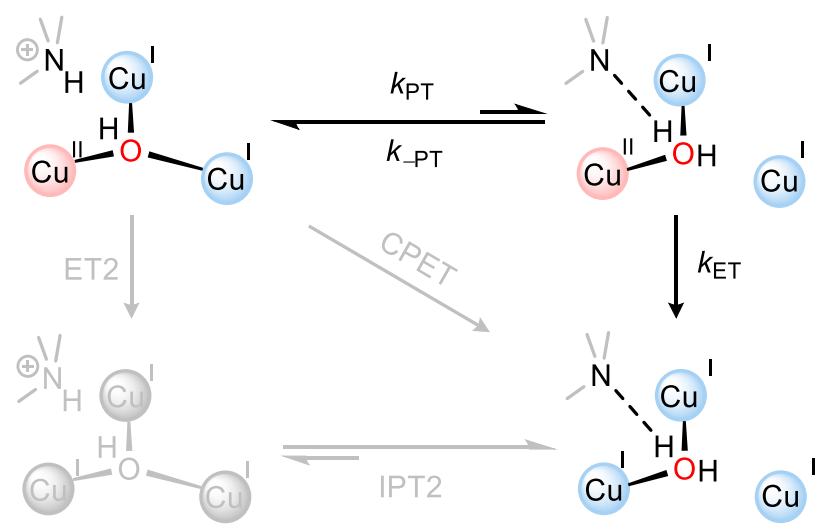

Scheme. S1. Mechanisms of PCET from $\mathrm{Cu}^{\mathrm{II}} \mathrm{Cu}^{\mathrm{I}} \mathrm{Cu}^{\mathrm{I}}\left(\mu_{3}-\mathrm{OH}\right) \mathbf{L H}$ to $\mathrm{Cu}^{\mathrm{I}} \mathrm{Cu}^{\mathrm{I}} \mathrm{Cu}^{\mathrm{I}}\left(\mu_{2}-\mathrm{OH}_{2}\right) \mathbf{L}$.

\section{Estimation of electron transfer rate between $\mathrm{Cu}^{\mathrm{II}} \mathrm{Cu}^{\mathrm{II}} \mathrm{Cu}^{\mathrm{I}}\left(\mu_{3}-\mathrm{OH}\right) \mathrm{L}$ and $\mathrm{Cu}^{\mathrm{II}} \mathrm{Cu}^{\mathrm{II}} \mathrm{Cu}^{\mathrm{I}}\left(\mu_{3}-\mathrm{O}\right) \mathrm{LH}$}

\section{Estimation of the electron self-exchange rate constants of $\mathrm{Cu}^{\mathrm{II}} \mathrm{Cu}^{\mathrm{II}} \mathrm{Cu}^{\mathrm{I}}\left(\mu_{3}-\mathrm{O}\right) \mathrm{LH}$}

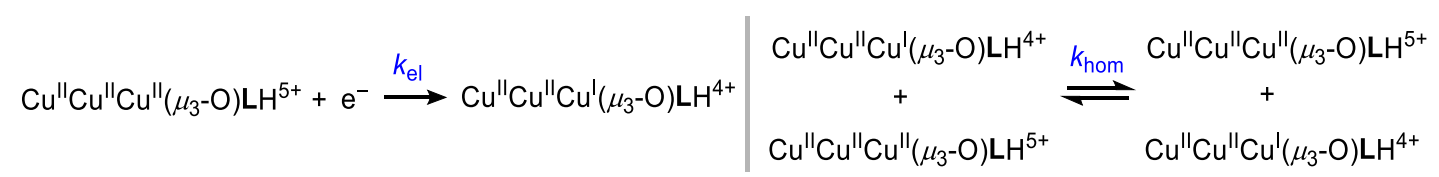

The standard electrochemical electron self-exchange rate constant $k_{\text {el }}(\mathrm{cm} / \mathrm{s})$ for $\mathrm{Cu}^{\mathrm{II}} \mathrm{Cu}^{\mathrm{II}} \mathrm{Cu}^{\mathrm{I}}\left(\mu_{3}-\right.$ O) $\mathbf{L H} / \mathrm{Cu}^{\mathrm{II}} \mathrm{Cu}^{\mathrm{II}} \mathrm{Cu}^{\mathrm{II}}\left(\mu_{3}-\mathrm{O}\right) \mathbf{L H}$ redox couple was estimated using an electrochemical method published previously. ${ }^{4,10,11}$ Under quasi-reversible conditions, $k_{\mathrm{el}}$ can be derived from Eq. 6 and 7:

$$
\begin{gathered}
\Psi=k_{e l}\left(\frac{D_{R}}{D_{O}}\right)^{\frac{\alpha}{2}}\left(\frac{R T}{n F \pi D_{R}}\right)^{1 / 2} v^{-1 / 2} \\
\Psi=\left(-0.6288+0.0021 n \Delta E_{p}\right) /\left(1-0.017 n \Delta E_{p}\right)
\end{gathered}
$$

where $\Psi$ is a kinetic parameter, $D_{\mathrm{R}}$ and $D_{\mathrm{O}}$ are the diffusion coefficients $\left(\mathrm{cm}^{2} / \mathrm{s}\right)$ of the reduced and oxidized species, respectively, $\alpha$ is the transfer coefficient for the electrode process, $R$ is gas constant $(8.314 \mathrm{~J} / \mathrm{mol} \mathrm{K}), T$ is temperature $(T=298 \mathrm{~K}), \mathrm{n}$ is the number of electrons transferred in each step ( $\mathrm{n}=1$ in this case), $F$ is the Faraday constant $(96485 \mathrm{C} / \mathrm{mol})$, and $v$ is the potential scan rate $(\mathrm{V} / \mathrm{s})$. The kinetic parameter $\Psi$ is also related to the peak-to-peak 
separation $\left(\Delta E_{\mathrm{p}}, \mathrm{mV}\right)$ of the anodic and cathodic waves in cyclic voltammogram by using the empirical equation (Eq. 7), where $\mathrm{n}$ is the number of electrons transferred in each step. $\Delta E_{\mathrm{p}}$ is obtained from cyclic voltammetry of $\mathrm{Cu}^{\mathrm{II}} \mathrm{Cu}^{\mathrm{II}} \mathrm{Cu}^{\mathrm{II}}\left(\mu_{3}-\mathrm{O}\right) \mathbf{L H}$ at a scan rate of $1.5 \mathrm{~V} / \mathrm{s}$ (Figure S26). Current interrupt (CI) measurement was performed before the cyclic voltammetry to account for uncompensated resistance $\left(R_{\mathrm{u}}\right)$. The values of $\Psi$ were calculated from the experimental $\Delta \mathrm{E}_{\mathrm{p}}$ values using the Eq. 7. The value of $D_{\mathrm{O}}$ was obtained using the RandlesSevcik equations $\left(4.5(2) \times 10^{-7} \mathrm{~cm}^{2} / \mathrm{s}\right.$, Figure S28). Due to the fast proton transfer of $\mathrm{Cu}^{\mathrm{II}} \mathrm{Cu}^{\mathrm{II}} \mathrm{Cu}^{\mathrm{I}}\left(\mu_{3}-\mathrm{O}\right) \mathbf{L H}$, it is difficult to measure $D_{\mathrm{R}}$ with $\mathrm{CV}$. Considering the minimal size variation during the redox for this type of tricopper complex, $D_{\mathrm{R}}$ was estimated to have the same value with $D_{\mathrm{O}}$. Then an estimation of the value of $k_{\mathrm{el}}$ was obtained $\left(1.43 \times 10^{-3} \mathrm{~cm} / \mathrm{s}\right)$. A correlation between $k_{\mathrm{el}}$ and the homogeneous electron self-exchange rate constant $k_{\mathrm{hom}}\left(\mathrm{M}^{-1} \mathrm{~s}^{-1}\right)$ has been described by Weaver et al. (Eq. 6): ${ }^{12}$

$$
k_{\text {hom }}=4 \pi N_{A} r_{h}{ }^{2} k_{e l} 10^{-19}
$$

where $k_{\text {el }}$ is the electrochemical rate constant $(\mathrm{cm} / \mathrm{s}), \mathrm{N}_{\mathrm{A}}$ is the Avogadro constant $\left(\mathrm{mol}^{-1}\right)$, and $\mathrm{r}_{\mathrm{h}}$ is the internuclear distance for self-exchange $(\AA)$. The value of $\mathrm{r}_{\mathrm{h}}(11.2 \AA)$ was estimated based on the atomic coordinates of the X-ray single-crystal structure $\mathrm{Cu}^{\mathrm{II}} \mathrm{Cu}^{\mathrm{II}} \mathrm{Cu}^{\mathrm{II}}\left(\mu_{3}-\mathrm{O}\right) \mathbf{L H}$ using Chemcraft software. The value of $k_{\text {hom }}$ was calculated as $1.35 \times 10^{5} \mathrm{M}^{-1} \mathrm{~s}^{-1}$ for $\mathrm{Cu}^{\mathrm{II}} \mathrm{Cu}^{\mathrm{II}} \mathrm{Cu}^{\mathrm{I}}\left(\mu_{3}-\mathrm{O}\right) \mathbf{L} \mathbf{H} / \mathrm{Cu}^{\mathrm{II}} \mathrm{Cu}^{\mathrm{II}} \mathrm{Cu}^{\mathrm{II}}\left(\mu_{3}-\mathrm{O}\right) \mathbf{L} \mathbf{H}$.

Calculation of the rate constant for the ET cross reaction between $\mathrm{Cu}^{\mathrm{II}} \mathrm{Cu}^{\mathrm{II}} \mathrm{Cu}^{\mathrm{I}}\left(\mu_{3}-\mathrm{OH}\right) \mathrm{L}$ and $\mathrm{Cu}^{\mathrm{II}} \mathrm{Cu}^{\mathrm{II}} \mathrm{Cu}^{\mathrm{I}}\left(\mu_{3}-\mathrm{O}\right) \mathrm{LH}$

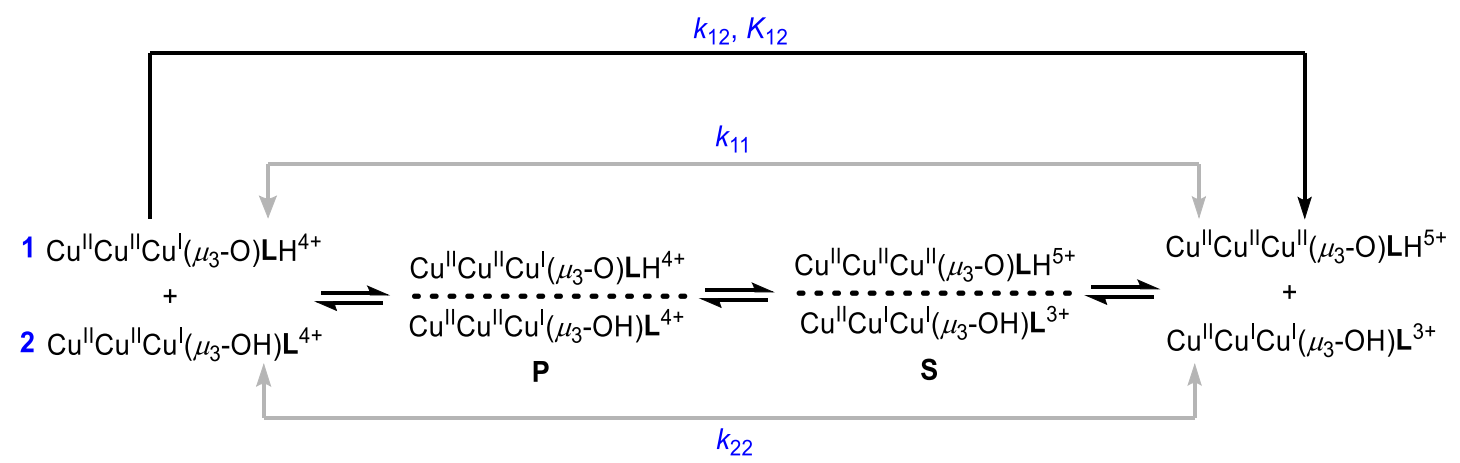

In the Marcus model, an electron transfer (ET) reaction is considered to proceed via initial formation of a weak precursor complex $\mathbf{P}$, which then undergoes ET to give the successor complex $\mathbf{S}$ that dissociates.

The rate constant $\left(k_{12}\right)$ for the ET cross reaction between $\mathrm{Cu}^{\mathrm{II}} \mathrm{Cu}^{\mathrm{II}} \mathrm{Cu}^{\mathrm{I}}\left(\mu_{3}-\mathrm{OH}\right) \mathrm{L}$ and $\mathrm{Cu}^{\mathrm{II}} \mathrm{Cu}^{\mathrm{II}} \mathrm{Cu}^{\mathrm{I}}\left(\mu_{3}-\mathrm{O}\right) \mathbf{L H}$ is estimated from the Marcus cross relation, ${ }^{13}$ which can be rearranged to give Eq. 9:

$$
k_{12}=\sqrt{k_{11} k_{22} K_{12} f_{12}} W_{12}
$$

In Eq. $9, \mathrm{k}_{11}$ is the self-exchange rate constant for $\mathrm{Cu}^{\mathrm{II}} \mathrm{Cu}^{\mathrm{II}} \mathrm{Cu}^{\mathrm{I}}\left(\mu_{3}-\mathrm{O}\right) \mathbf{L H} / \mathrm{Cu}^{\mathrm{II}} \mathrm{Cu}^{\mathrm{II}} \mathrm{Cu}^{\mathrm{II}}\left(\mu_{3}-\mathrm{O}\right) \mathbf{L H}$ which is calculated in the previous section, $k_{22}$ is the self-exchange rate constant for $\mathrm{Cu}^{\mathrm{II}} \mathrm{Cu}^{\mathrm{I}} \mathrm{Cu}^{\mathrm{I}}\left(\mu_{3}-\mathrm{OH}\right) \mathbf{L} / \mathrm{Cu}^{\mathrm{II}} \mathrm{Cu}^{\mathrm{II}} \mathrm{Cu}^{\mathrm{I}}\left(\mu_{3}-\mathrm{OH}\right) \mathbf{L}$, which has been reported in the literature, ${ }^{4} K_{12}$ is the equilibrium constant derived from the known redox potential of $\mathrm{Cu}^{\mathrm{II}} \mathrm{Cu}^{\mathrm{II}} \mathrm{Cu}^{\mathrm{I}}\left(\mu_{3}-\mathrm{O}\right) \mathbf{L H} /$ $\mathrm{Cu}^{\mathrm{II}} \mathrm{Cu}^{\mathrm{II}} \mathrm{Cu}^{\mathrm{II}}\left(\mu_{3}-\mathrm{O}\right) \mathbf{L H}$ and $\mathrm{Cu}^{\mathrm{II}} \mathrm{Cu}^{\mathrm{I}} \mathrm{Cu}^{\mathrm{I}}\left(\mu_{3}-\mathrm{OH}\right) \mathbf{L} / \mathrm{Cu}^{\mathrm{II}} \mathrm{Cu}^{\mathrm{II}} \mathrm{Cu}^{\mathrm{I}}\left(\mu_{3}-\mathrm{OH}\right) \mathbf{L}, W_{12}$ is a term associated with the work required to bring the reactants/products together in the 
precursor/successor complexes (vide infra), and $f_{12}$ is a known function of $k_{11}, k_{12}, \mathrm{~K}_{12}$, and the individual work terms for the cross- and self-exchange reactions.

$W_{12}$ is defined by Eq. $10:{ }^{13}$

$$
W_{12}=\exp \left(\frac{-\left(w_{12}+w_{21}-w_{11}-w_{22}\right)}{2 R T}\right)
$$

where $w_{12}$ corresponds to the electrostatic work term for bringing $\mathrm{Cu}^{\mathrm{II}} \mathrm{Cu}^{\mathrm{II}} \mathrm{Cu}^{\mathrm{I}}\left(\mu_{3}-\mathrm{O}\right) \mathbf{L H}$ and $\mathrm{Cu}^{\mathrm{II}} \mathrm{Cu}^{\mathrm{II}} \mathrm{Cu}^{\mathrm{I}}\left(\mu_{3}-\mathrm{OH}\right) \mathbf{L}$ to the mean distance for ET (the forward reaction), $w_{21}$ corresponds to the electrostatic work term for bringing $\mathrm{Cu}^{\mathrm{II}} \mathrm{Cu}^{\mathrm{II}} \mathrm{Cu}^{\mathrm{II}}\left(\mu_{3}-\mathrm{O}\right) \mathbf{L} \mathbf{H}$ and $\mathrm{Cu}^{\mathrm{II}} \mathrm{Cu}^{\mathrm{II}} \mathrm{Cu}^{\mathrm{II}}\left(\mu_{3}-\mathrm{O}\right) \mathbf{L H}$ to the mean distance for ET (the reverse reaction). $w_{11}$ and $w_{22}$ correspond to the electrostatic work term for self-exchange of $\mathrm{Cu}^{\mathrm{II}} \mathrm{Cu}^{\mathrm{II}} \mathrm{Cu}^{\mathrm{I}}\left(\mu_{3}-\mathrm{O}\right) \mathbf{L H} / \mathrm{Cu}^{\mathrm{II}} \mathrm{Cu}^{\mathrm{II}} \mathrm{Cu}^{\mathrm{II}}\left(\mu_{3}-\mathrm{O}\right) \mathbf{L H}$ and $\mathrm{Cu}^{\mathrm{II}} \mathrm{Cu}^{\mathrm{I}} \mathrm{Cu}^{\mathrm{I}}\left(\mu_{3}-\right.$ $\mathrm{OH}) \mathbf{L} / \mathrm{Cu}^{\mathrm{II}} \mathrm{Cu}^{\mathrm{II}} \mathrm{Cu}^{\mathrm{I}}\left(\mu_{3}-\mathrm{OH}\right) \mathbf{L}$, respectively.

The electrostatic work terms can be estimated from Eq. 11: ${ }^{14}$

$$
w_{12}=\frac{Z_{1} Z_{2} e^{2} f}{D r_{12}}
$$

where $Z_{1}$ and $Z_{2}$ are the charges on the species to be oxidized and reduced, respectively, $e$ is the elementary charge $\left(e^{2}=332.1 \mathrm{kcal} \AA \mathrm{mol}^{-1}\right), f$ is the Debye screening factor that defines the effect of ionic strength, $D$ is the static dielectric constant of the solvent (35.87, MeCN 298K), and $r_{12}$ is the center-to-center distance between contacting reagents.

The Debye screening factor is given by Eq. 12:

$$
f=\left\{1+r_{12} \sqrt{\frac{8 \pi e^{2} \mu}{10^{27} D k_{B} T}}\right\}
$$

where $\mathrm{k}_{\mathrm{B}}$ is Boltzmann's constant $\left(1.38 \times 10^{-23} \mathrm{~J} / \mathrm{K}\right), \mu$ is the ionic strength $(0.0034 \mathrm{M}$, derived from a total $0.0004 \mathrm{M}$ of $\mathrm{Cu}^{\mathrm{II}} \mathrm{Cu}^{\mathrm{II}} \mathrm{Cu}^{\mathrm{I}}\left(\mu_{3}-\mathrm{O}\right) \mathbf{L H} / \mathrm{Cu}^{\mathrm{II}} \mathrm{Cu}^{\mathrm{II}} \mathrm{Cu}^{\mathrm{I}}\left(\mu_{3}-\mathrm{O}\right) \mathbf{L H}$ and $0.0004 \mathrm{M}$ of $\left.\mathrm{Cp}_{2} \mathrm{Co}^{+}\right)$, and $T$ is temperature $(298 \mathrm{~K})$.

The $f_{12}$ term in Eq. 9 is defined by Eq. $13::^{13}$

$$
f_{12}=\exp \left[0.25 \frac{\left(\ln K_{12}+\frac{w_{12}}{R T}\right)^{2}}{\ln \left(\frac{k_{11} k_{22}}{Z^{2}}\right)}\right]
$$

where $Z$ is the collision frequency, taken to be $10^{11} \mathrm{M}^{-1} \mathrm{~s}^{-1} \cdot 13,15$

So, the rate constant $k_{12}$ for the ET cross reaction between $\mathrm{Cu}^{\mathrm{II}} \mathrm{Cu}^{\mathrm{II}} \mathrm{Cu}^{\mathrm{I}}\left(\mu_{3}-\mathrm{OH}\right) \mathbf{L}$ and $\mathrm{Cu}^{\mathrm{II}} \mathrm{Cu}^{\mathrm{II}} \mathrm{Cu}^{\mathrm{I}}\left(\mu_{3}-\mathrm{O}\right) \mathbf{L H}$ is estimated to be $2.45 \times 10^{6} \mathrm{M}^{-1} \mathrm{~s}^{-1}$ at $25^{\circ} \mathrm{C}$.

In order to extend the estimation of $k_{12}$ values to other temperatures, the activation energy analysis was performed with Eq. 14 and Eq. 15:

$$
\begin{aligned}
k_{12} & =Z \exp \left(\frac{-\Delta G^{*}}{R T}\right) \\
\Delta G^{*} & =\Delta H^{*}-T \Delta S^{*}
\end{aligned}
$$

where $Z$ is the collision frequency, $\Delta G^{*}$ is activation free energy, $\Delta H^{*}$ is activation enthalpy, and $\Delta S^{*}$ is the activation entropy. Since the ET cross reaction between $\mathrm{Cu}^{\mathrm{II}} \mathrm{Cu}^{\mathrm{II}} \mathrm{Cu}^{\mathrm{I}}\left(\mu_{3}-\mathrm{OH}\right) \mathbf{L}$ and $\mathrm{Cu}^{\mathrm{II}} \mathrm{Cu}^{\mathrm{II}} \mathrm{Cu}^{\mathrm{I}}\left(\mu_{3}-\mathrm{O}\right) \mathbf{L H}$ needs an initial bimolecular reaction, the activation entropy $\left(\Delta S^{*}\right)$ should be negative, which means that the activation free energy $\left(\Delta G^{*}\right)$ will decrease when the temperature is lowered. Although we cannot estimate the value for $k_{12}$ at different temperatures with the available information, we can still provide the lowest estimations for $k_{12}$ at different temperatures. If we assume that $\Delta G^{*}$ does not change with temperature, the $k_{12}$ value can be obtained with Eq. 13: $6.88 \times 10^{4} \mathrm{M}^{-1} \mathrm{~s}^{-1}\left(-50{ }^{\circ} \mathrm{C}\right), 3.53 \times 10^{4} \mathrm{M}^{-1} \mathrm{~s}^{-1}\left(-60{ }^{\circ} \mathrm{C}\right), 1.70 \times 10^{4}$ $\mathrm{M}^{-1} \mathrm{~s}^{-1}\left(-70{ }^{\circ} \mathrm{C}\right)$, and $7.57 \times 10^{3} \mathrm{M}^{-1} \mathrm{~s}^{-1}\left(-80{ }^{\circ} \mathrm{C}\right)$. However, due to the lower $\Delta G^{*}$ at lower 
temperatures, the actual $k_{12}$ should be larger than the numbers above at the corresponding temperature, which means the actual $\mathrm{k}_{12}$ should be $>6.88 \times 10^{4} \mathrm{M}^{-1} \mathrm{~s}^{-1}\left(-50^{\circ} \mathrm{C}\right),>3.53 \times 10^{4}$ $\mathrm{M}^{-1} \mathrm{~s}^{-1}\left(-60^{\circ} \mathrm{C}\right),>1.70 \times 10^{4} \mathrm{M}^{-1} \mathrm{~s}^{-1}\left(-70{ }^{\circ} \mathrm{C}\right)$, and $>7.57 \times 10^{3} \mathrm{M}^{-1} \mathrm{~s}^{-1}\left(-80^{\circ} \mathrm{C}\right)$.

\section{Reference}

1. Scharnagl, F. K., Hertrich, M. F., Neitzel, G., Jackstell, R. \& Beller, M. Homogeneous catalytic hydrogenation of $\mathrm{CO}_{2}$ to methanol-improvements with tailored ligands. $A d v$. Synth. Catal. 361, 374-379 (2019).

2. Le Bras, J., Jiao, H., Meyer, W. E., Hampel, F. \& Gladysz, J. . Synthesis, crystal structure, and reactions of the 17-valence-electron rhenium methyl complex $\left[\left(\eta^{5}-\right.\right.$ $\left.\left.\mathrm{C}_{5} \mathrm{Me}_{5}\right) \mathrm{Re}(\mathrm{NO})\left(\mathrm{P}\left(4-\mathrm{C}_{6} \mathrm{H}_{4} \mathrm{CH}_{3}\right)_{3}\right)\left(\mathrm{CH}_{3}\right)\right]^{+} \quad \mathrm{B}\left(3,5-\mathrm{C}_{6} \mathrm{H}_{3}\left(\mathrm{CF}_{3}\right)_{2}\right)_{4}{ }^{-}$: experimental and computational bonding comparisons with 18-electron methyl and methylidene complexes. J. Organomet. Chem. 616, 54-66 (2000).

3. Bower, J. K., Cypcar, A. D., Henriquez, B., Stieber, S. C. E. \& Zhang, S. C(sp $\left.{ }^{3}\right)-H$ fluorination with a copper(II)/(III) redox couple. J. Am. Chem. Soc. 142, 8514-8521 (2020).

4. Zhang, W., Moore, C. E. \& Zhang, S. Encapsulation of tricopper cluster in a synthetic cryptand enables facile redox processes from $\mathrm{Cu}^{\mathrm{I}} \mathrm{Cu}^{\mathrm{I}} \mathrm{Cu}^{\mathrm{I}}$ to $\mathrm{Cu}^{\mathrm{II}} \mathrm{Cu}^{\mathrm{II}} \mathrm{Cu}^{\mathrm{II}}$ states. Chem. Sci. 12, 2986-2992 (2021).

5. Johnson, K. A., Simpson, Z. B. \& Blom, T. Global Kinetic Explorer: A new computer program for dynamic simulation and fitting of kinetic data. Anal. Biochem. 387, 20-29 (2009).

6. Johnson, K. A., Simpson, Z. B. \& Blom, T. FitSpace Explorer: An algorithm to evaluate multidimensional parameter space in fitting kinetic data. Anal. Biochem. 387, 30-41 (2009).

7. Rudolph, M. Digital simulations on unequally spaced grids: Part 2. Using the box method by discretisation on a transformed equally spaced grid. J. Electroanal. Chem. 543, 23-39 (2003).

8. Rhile, I. J. \& Mayer, J. M. One-electron oxidation of a hydrogen-bonded phenol occurs by concerted proton-coupled electron transfer. J. Am. Chem. Soc. 126, 12718-12719 (2004).

9. Tyburski, R., Liu, T., Glover, S. D. \& Hammarström, L. Proton-coupled electron transfer guidelines, fair and Square. J. Am. Chem. Soc. 143, 560-576 (2021).

10. Lavagnini, I., Antiochia, R. \& Magno, F. An extended method for the practical evaluation of the standard rate constant from cyclic voltammetric data. Electroanalysis 16, 505-506 (2004).

11. Gennari, M. et al. A fully delocalized mixed-valence bis- $\mu$ (thiolato) dicopper complex: a structural and functional model of the biological $\mathrm{Cu}_{\mathrm{A}}$ center. Angew. Chemie Int. Ed. 50, 5662-5666 (2011).

12. Weaver, M. J. An alternative approach to the intercomparison of electron-transfer reactivities at metal surfaces and in homogeneous solution1. J. Phys. Chem. 94, 86088613 (1990). 
13. R.A. Marcus and Norman Sutin. Electron transfers in chemistry and biology. Biochim. Biophys. Acta 811, 265-322 (1985).

14. Nelsen, S. F. Electron Transfer Reactions in Organic Chemistry. 25, (Springer Berlin Heidelberg, 1987).

15. Tahsini, L. et al. Electron-transfer reduction of dinuclear copper peroxo and bis- $\mu$-oxo complexes leading to the catalytic four-electron reduction of dioxygen to water. Chem. - A Eur. J. 18, 1084-1093 (2012). 